\title{
The Hale and Keith Mounds in the Big Cypress Creek Basin in East Texas
}

Timothy K. Perttula

Heritage Research Center, Stephen F. Austin State University

Follow this and additional works at: https://scholarworks.sfasu.edu/ita

Part of the American Material Culture Commons, Archaeological Anthropology Commons, Environmental Studies Commons, Other American Studies Commons, Other Arts and Humanities Commons, Other History of Art, Architecture, and Archaeology Commons, and the United States History Commons

Tell us how this article helped you.

This Article is brought to you for free and open access by the Center for Regional Heritage Research at SFA ScholarWorks. It has been accepted for inclusion in Index of Texas Archaeology: Open Access Gray Literature from the Lone Star State by an authorized editor of SFA ScholarWorks. For more information, please contact cdsscholarworks@sfasu.edu. 


\section{The Hale and Keith Mounds in the Big Cypress Creek Basin in East Texas \\ Creative Commons License \\ (c) (1) \& 8}

This work is licensed under a Creative Commons Attribution-NonCommercial 4.0 International License 


\section{The Hale and Keith Mounds in the Big Cypress Creek Basin in East Texas}

Timothy K. Perttula, Robert Z. Selden, Jr., and Leslie L. Bush

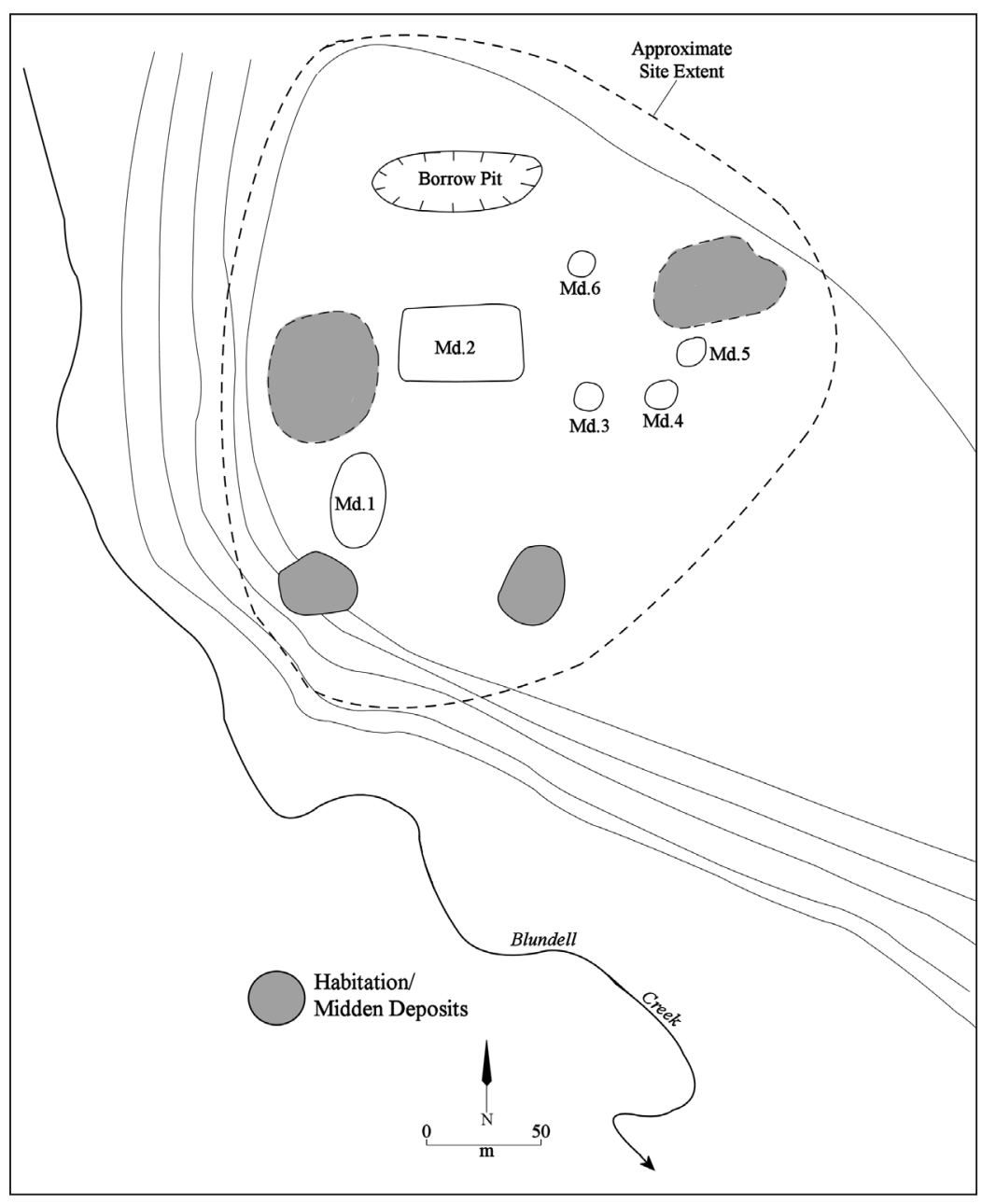

Special Publication No. 33

Friends of Northeast Texas Archaeology 
Distribution, Bo Nelson, 344 CR 4154

Pittsburg, Texas 75686

RBoNelson@aol.com

\section{Cover art:}

Map of the Hale site (41TT12)

Copyright (C) 2014, Friends of Northeast Texas Archaeology (Austin and Pittsburg) 


\section{Table of Contents}

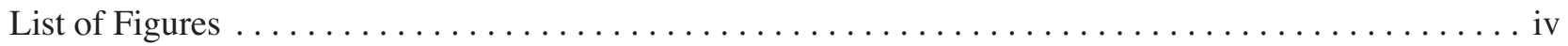

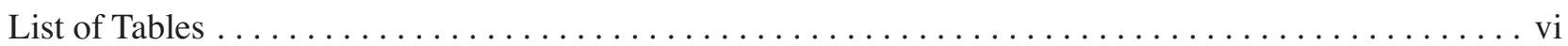

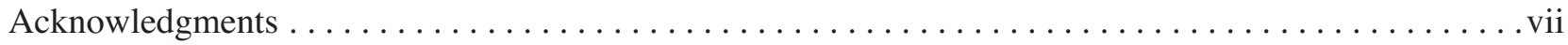

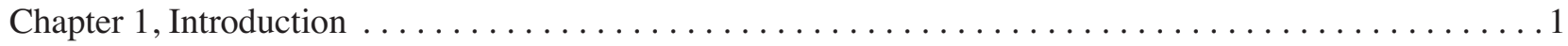

Chapter 2, Archaeological Investigations at the L. A. Hale Mound Site (41TT12) $\ldots \ldots \ldots \ldots \ldots$

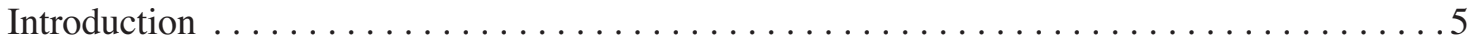

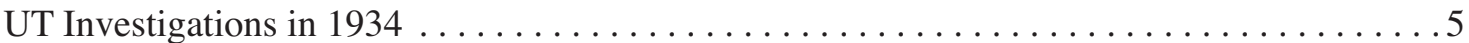

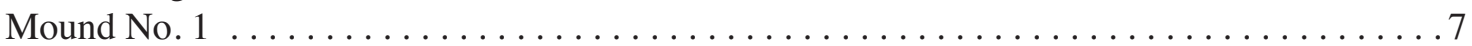

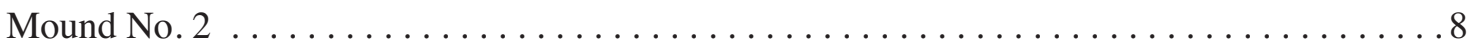

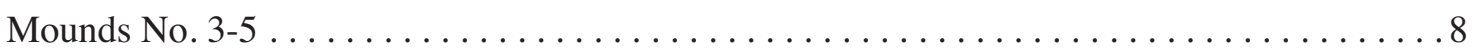

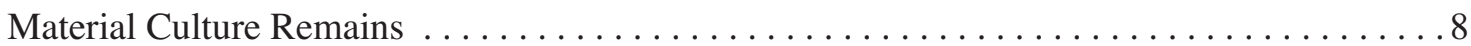

Chapter 3, Archaeological Investigations at the George L. Keith Site (41TT11) . . . . . . . . . . . 23

Material Culture Remains . . . . . . . . . . . . . . . . . . . . . . . . 32

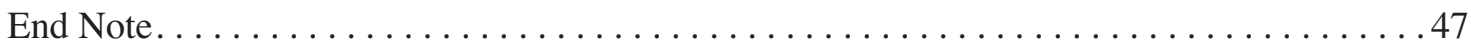

Chapter 4, Radiocarbon Dates from the Hale and Keith Sites. . . . . . . . . . . . . . . . . . . 49

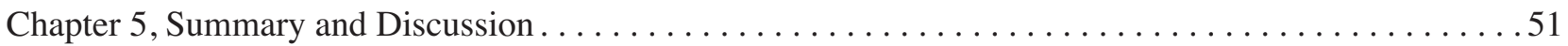

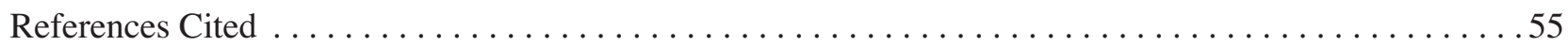




\section{List of Figures}

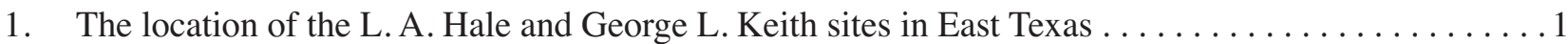

2. Map of the L. A. Hale site (after Thurmond 1990:Figure 24) $\ldots \ldots \ldots \ldots \ldots \ldots \ldots \ldots \ldots \ldots \ldots \ldots \ldots \ldots$

3. Schematic profiles of Mounds No. 1 and No. 2 at the Hale site $\ldots \ldots \ldots \ldots \ldots \ldots \ldots \ldots \ldots$

4. Appliqued and fingernail punctated rim and body sherd decorative elements:

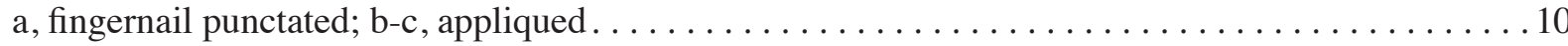

5. Incised and Incised-appliqued rim and lower rim sherd decorative elements:

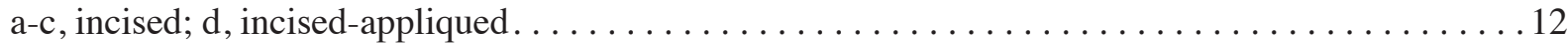

6. Incised-punctated rim and body sherd decorative elements: a, d-f, body sherds;

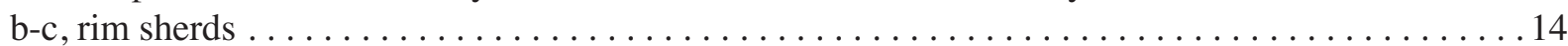

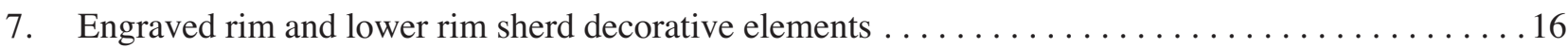

8. Engraved bottle body sherd decorative elements: a-c, engraved; d, engraved-punctated . . . . . . . 18

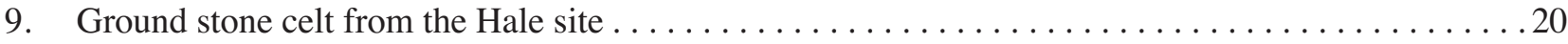

10. Bone tools and alligator tooth pendant: a-c, bone tools; $d-d$ ', alligator tooth pendant ..........21

11. The mound at the George L. Keith site, other areas with occupational debris, the terrace remnant where the Titus phase cemetery is located, and 1971 auger test locations (redrawn from Brown 1971a) . . . . . . . . . . . . . . . . . . . . . . . . . . . . 23

12. Features and post holes exposed in the sub-mound midden deposits in the 1934 trench cutting through the Keith mound (Redrawn from Brown 1971a) . . . . . . . . . . . . 24

13. Plan of Features 1-3 in the floor of the trench cut through the Keith mound

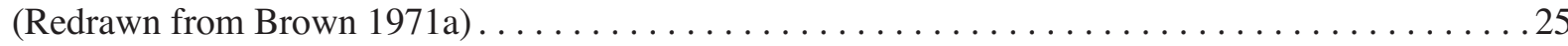

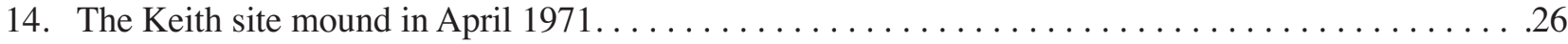

15. Looking west at the mound at the Keith site after the northern half was leveled

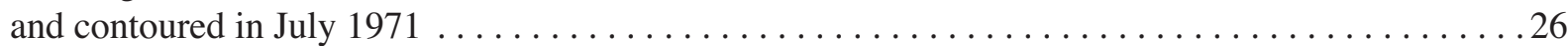

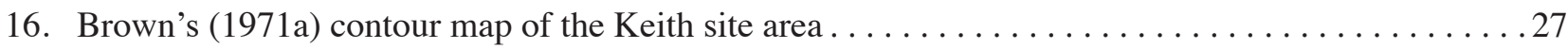

17. 1971 Profile of a section of the 1934 UT trench through the Keith mound . . . . . . . . . . . . 28

18. Photograph of the cleaned 1971 profile in the UT trench in the Keith Mound . . . . . . . . . . . . . 29

19. Large engraved compound bowl in a private collection from the Titus phase cemetery area. Photograph taken by Milton Bell in September 1975 . . . . . . . . . . . . . . 30

20. Engraved motifs on Ripley Engraved carinated bowls in the Ed German collection from the Keith site: a, Ripley Engraved, var. McKinney (G-11/16); b, Ripley Engraved, var. Galt (G-11/20); c, Ripley Engraved, var. unspecified (G-11/13) . . . . . . . . . . . . . 32

21. Incised rim and body sherd decorative elements: a-g, rim sherds; $h-i$, body sherds $\ldots \ldots \ldots \ldots 36$

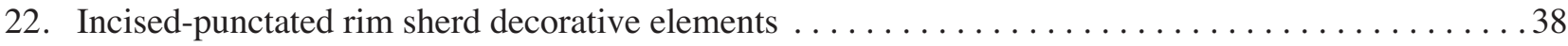

23. Incised-punctated and punctated body and lower rim sherd decorative elements:

a-c, incised-punctated; d, Weches Fingernail Impressed, var. Alto . . . . . . . . . . . . . . . . . . 39 
24. Engraved rim and body sherd decorative elements $\ldots \ldots \ldots \ldots \ldots \ldots \ldots \ldots \ldots \ldots \ldots \ldots \ldots \ldots \ldots \ldots \ldots \ldots$

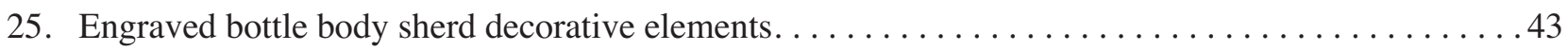

26. Late Caddo fine ware and utility ware sherd decorative elements: a-f, Ripley Engraved;

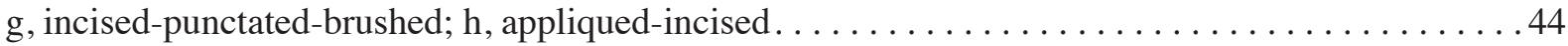

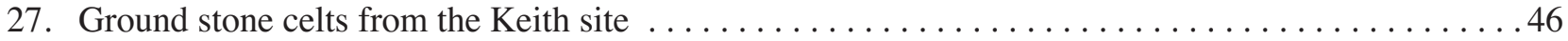

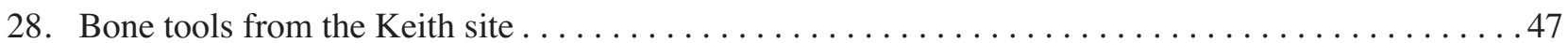




\section{List of Tables}

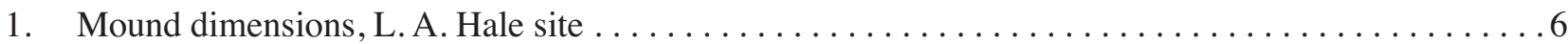

2. Use of bone temper in utility ware and fine ware sherds from the Hale site $\ldots \ldots \ldots \ldots \ldots \ldots$

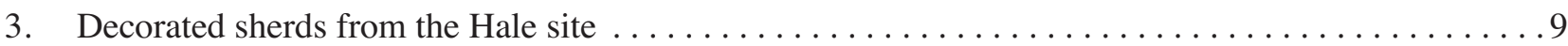

4. Decorative elements on incised rim and body sherds from the Hale site $\ldots \ldots \ldots \ldots \ldots \ldots \ldots 11$

5. Decorative elements on incised-punctated rim and body sherds from the Hale site ...........13

6. Decorative elements on fingernail and tool punctated rim and body sherds from

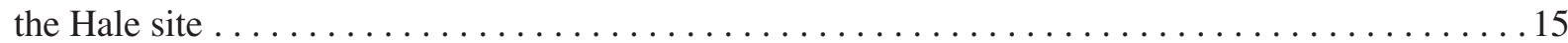

7. Decorative elements on Early Caddo engraved bowl and carinated bowl rim and

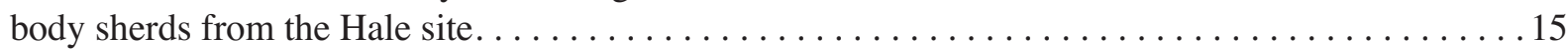

8. Decorative elements on Early Caddo engraved and engraved-punctated bottle sherds

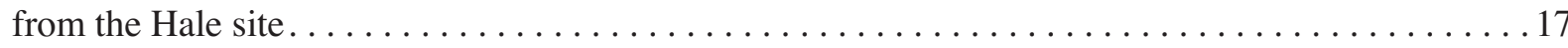

9. Available information on vessels in the Ed German collection from the Keith site ............31

10. Use of bone temper in utility ware and fine ware sherds from the Keith site $\ldots \ldots \ldots \ldots \ldots \ldots 33$

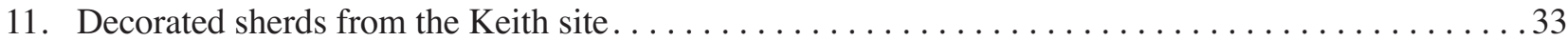

12. Decorative elements on incised rim and body sherds from the Keith site $\ldots \ldots \ldots \ldots \ldots \ldots \ldots$

13. Decorative elements on incised-punctated rim and body sherds from the Keith site $\ldots \ldots \ldots \ldots 37$

14. Decorative elements on fingernail and tool punctated rim and body sherds from the Keith site . . . .40

15. Decorative elements on engraved bowl and carinated rim and body sherds from the Keith site .....41

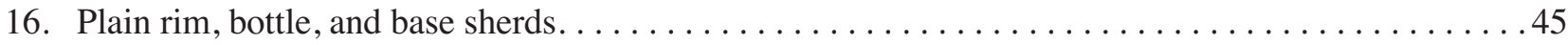

17. Radiocarbon dates from the Keith (41TT11) and Hale (41TT12) sites . . . . . . . . . . 50 


\section{Acknowledgments}

Laura Nightengale at the Texas Archeological Research Laboratory, The University of Texas at Austin greatly facilitated the study of the collections from the Hale and Keith sites, particularly in her efforts to help track down the animal bones from both sites in Building 33. Thanks to Lance Trask for preparing the figures in this publication, and to Robert Z. Selden Jr. for calibrating the five new radiocarbon dates from the two sites. I appreciate Kenneth M. Brown sharing information on his work at the Keith site in 1971, and on his documentation of the Ed German collection from the site in 1972. Thanks also to Waldo Troell for the use of several photographs taken by Milton Bell in 1971 of the Keith site, as well as a later photograph of one of the vessels recovered there by avocational archaeologists from an ancestral Caddo burial. 



\section{Chapter 1, Introduction}

The L. A. Hale (41TT12) and George L. Keith (41TT11) sites are two important ancestral Caddo mound centers in the Big Cypress Creek basin in the Post Oak Savanna of East Texas (Figure 1). Between them, they appear to have been occupied by Caddo peoples between ca. A.D. 1000-1400, although they may not have been occupied contemporaneously. Key questions that I hope to answer in this publication are: (1) when were the sites occupied and when were the mounds on them constructed, and (2) what were the mounds and the sites used for? These questions are challenging because both sites were excavated more than 80 years ago, during a much earlier era in East Texas Caddo archaeology, and available records and collected archaeological data fall far short of what modern-day archaeological investigations at the two sites could routinely obtain during field work in mound and habitation features. Further-

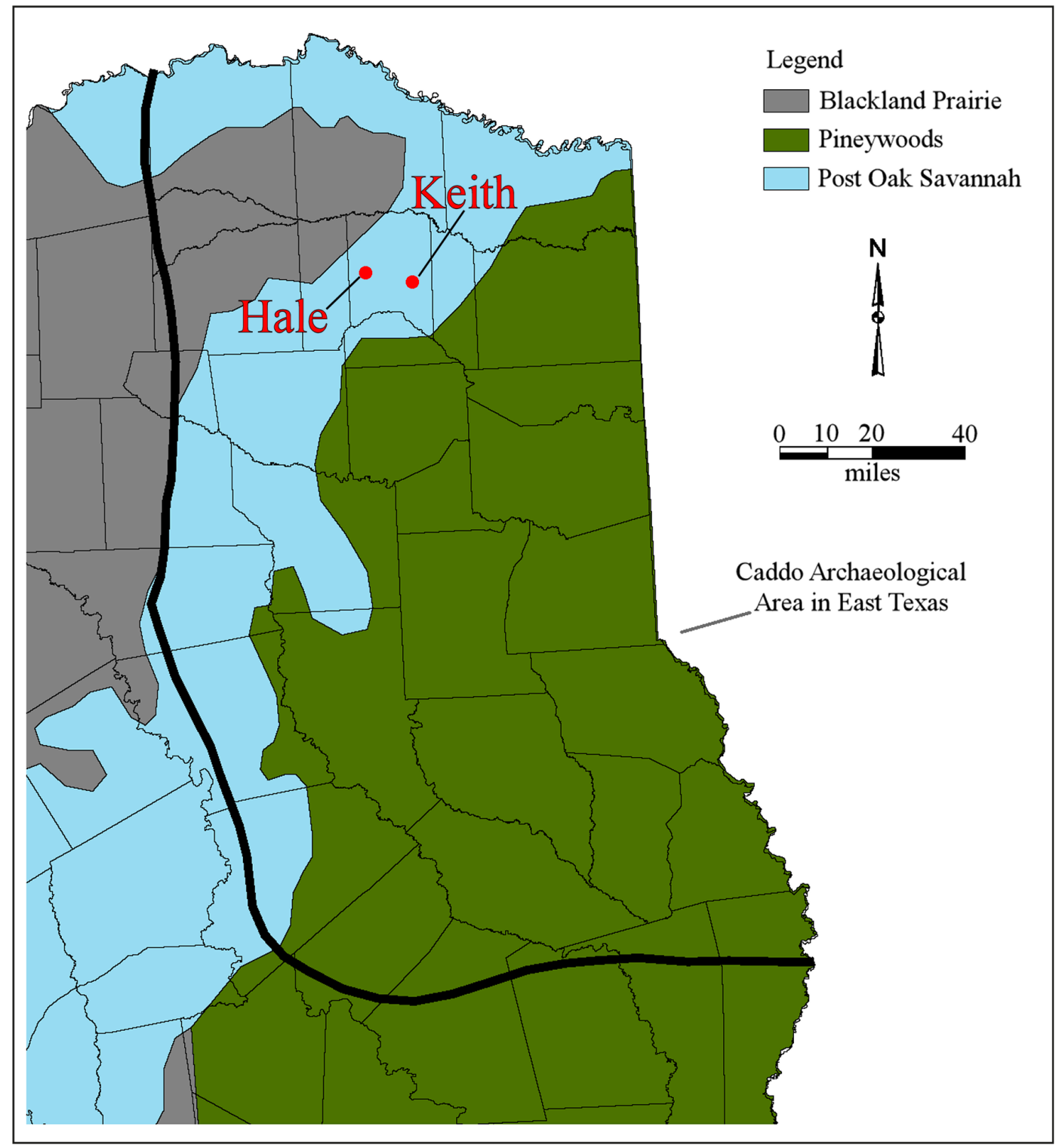

Figure 1. The location of the L. A. Hale and George L. Keith sites in East Texas. 
more, the 1934 archaeological investigations at the Hale and Keith sites have never been published - or the material culture remains in the collections fully studied and reported - and thus there are research voids in the study of the sites that must be overcome to be able to understand the place of the two sites within the modern framework of Caddo archaeological research in the region.

These mound sites were likely the nexus of different Caddo communities, as they contained evidence of mounds and ritual buildings (on as well as underneath the mounds), as well as religious practices and ceremonies that were conducted at the two sites and in the temples and other important buildings on the mounds, that were key to integrating different farmsteads and households in Big Cypress Creek basin communities (see Thurmond 1990:Figure 12) and binding them together. The construction of earthen mounds at these Caddo sites was certainly an important part of religious life and ritual in these East Texas Caddo societies. The rituals that were carried out in important structures at these mound sites not only would have fulfilled religious obligations, but as Spielmann (2009:179) notes, these rituals would have been a source of political power, "in that people with ritual knowledge have political influence. In addition, those who are able to organize elaborate ritual performances and feasts gain a measure of prestige within their societies." Such rituals would also be the context for much social interaction between members of the Caddo communities that frequented the mound centers and viewed them as key places in the landscape of their communities.

Anderson and Sassaman (2012:168) have noted that the construction of monumental earthen architecture was an important aspect of post-A.D. 900-1000 life in eastern North American, as it was in the Caddo area. Accordingly, mounds are a key aspect of the archaeological record that has been used to assess and judge the complexity and socio-political organization of aboriginal peoples (see Anderson 2012) and the relationships of peoples to "creation, the sources of life, and the intersection of cosmic and human fields" (Pauketat 2013:165). Hopefully, the archaeological evidence gathered from the Hale and Keith site over the years, including this recent restudy of the records and material culture remains, will lend insights into such realms (e.g., what Pauketat [2013:164) refers to as cosmic deposits).

Recently, and more locally, Ross C. Fields (2014:134-136) has argued regarding the Keith site that it:

may be best interpreted as a ceremonial site with multiple associated residential areas that was established during the Middle Caddo period and continued to be used during the Late Caddo period. Given its proximity and the impressive and persistent presence on the landscape that the mound provided, it is hard to believe that the rituals performed there did not include family groups who lived a short distance to the west on Tankersley Creek. What is intriguing about Keith is that the mound there is far larger than any other Titus phase mound. It covers almost 14 times the area and is 5-6 times taller than the average Titus heartland mound for which size data are known...The size difference relates partly to the fact that the mound at Keith likely served a different function than most Titus phase mounds, i.e., it was a platform built in stages to support important buildings rather than a small tumulus that formed through the destruction and capping of one or two small ritual-associated structures. This implies that the ceremonies performed there may have been different than those at most other mound sites.

Perspectives such as this for the Keith site are just as important at the (earlier) Hale site, since while Keith site has one relatively large mound (containing at least $16,450 \mathrm{~m}^{3}$ of earth), the Hale site has six mounds, extensive habitation debris, and likely at least one or more plaza areas (see Chapter 2). The two largest mounds at the site, both platform mounds, range from containing at least $4100-5490 \mathrm{~m}^{3}$ of earth; the four smaller mounds at the Hale site contain only between 112-202 $\mathrm{m}^{3}$ of mound deposits. All of the mounds at both sites likely were built to elevate and/or cap important structures that were used for re- 
ligious and political rituals and ceremonies conducted by religious and political leaders in Big Cypress Creek basin Caddo communities, and the actual construction of the mounds (including different colored and textured fills) had important ritual and symbolic meanings. These mound volumes likely indicate that their construction required "the cooperative activity of ...larger numbers of people and presumably multiple social groups" (Anderson and Sassaman 2012:167).

Chapters 2 and 3 in this Special Publication discuss the history of archaeological investigations at the two sites, which were centered on the trenching of different mounds rather than the exploration of habitation deposits and middens, and the analysis of the diverse sets of material culture remains (especially ceramic vessel sherds) recovered in the work. Chapter 4 considers the radiocarbon dates that have been obtained from the sites - including the recent set of five dates obtained on animal bones from mound and sub-mound midden contexts at Hale and Keith - to determine (in conjunction with the study of ceramic stylistic characteristics in the decorated sherds) when these sites were occupied and used by ancestral Caddo peoples. The concluding chapter summarizes the archaeological findings from the Hale and Keith sites based on the available archaeological records and artifacts, and discusses the uses of the sites for mound-related rituals and ceremonies as well as habitation. 



\section{Chapter 2, Archaeological Investigations at the L.A. Hale Mound Site (41TT12)}

\section{Introduction}

The L. A. Hale Mound site (41TT12) is situated on a broad alluvial terrace of Blundell Creek, a southward-flowing tributary to Big Cypress Creek. Two natural springs are also in the vicinity, about 400 $\mathrm{m}$ from the site. The excavations at the site by the University of Texas at Austin (UT) were completed between May 11-28, 1934.

According to Thurmond (1990:187), the principal component at the L. A. Hale Mound site is an Early Caddo (ca. A.D. 900-1200) mound center with extensive midden deposits. There are six mounds at the site, two large platform mounds (Mounds 1 and 2) and four low mounds that cover occupational deposits and burned house structures. There are also four large midden areas adjacent to the earthen mounds as well as at least one borrow pit (Thurmond 1990:Figure 24). In addition to the Early Caddo component, Thurmond (1990:187) has recognized Late Paleoindian, Early Archaic, Middle Archaic, Late Caddo Titus phase, and an early historic Anglo-American occupation from material culture remains recovered in excavations conducted at the site in 1934 by A. T. Jackson (1934) at The University of Texas and a 1980 surface collection by Susan Lisk of The University of Texas at Austin.

Robert L. Turner also obtained a surface collection of artifacts from the site (Perttula 2013:27-30). They primarily reflect the fact that the primary component at the site appears to date from the Early Caddo period (ca. A.D. 900-1200). Diagnostic ceramic sherds from this component in Turner's collection include a Holly Fine Engraved rim sherd and a possible Coles Creek Incised, var. Chase body sherd. There are unidentified engraved fine wares from carinated bowls as well as a red-slipped bowl or carinated bowl sherd, and incised and tool punctated utility wares. The lithic artifacts include a ca. A.D. 200-700 Gary, var. Camden dart point, indicative of some use of the L. A. Hale Mound site during the Woodland period and a large ferruginous sandstone biface, which may be from a limited Middle or Late Archaic period use.

\section{UT Investigations in 1934}

At the time of the UT investigations at the Hale site in May 1934, two large mounds and two small mounds were apparent on the landform, as well as midden deposits, and an ancestral Caddo cemetery "in a sandy valley between the mounds" (Jackson n.d.), but Jackson (1934:1) stated that there are six mounds (Nos. 1-6) at the site. Artifacts noted on the surface by Jackson (1934:5), primarily dart points, indicate some use of the site during both Late Archaic and Woodland period times, but the principal occupation was by ancestral Caddo peoples.

Mound dimensions are provided in Table 1. Mounds No. 1 and 2 are in the central and southwestern part of the site, with a large borrow pit ca. $40 \mathrm{~m}$ north of Mound No. 2, a rectangular platform mound (Figure 2). The four much smaller mounds cluster to the east and northeast of Mound No. 2. Caddo midden deposits with pottery sherds, animal bones, mussel shell, and chipped stone are concentrated south and north of Mound No. 1, west of Mound No. 2, and north and northeast of Mound No. 5; animal bones and mussel shells were particularly dense in this latter midden deposit. The midden deposits north of Mound No. 1 and west of Mound No. 2 are between 46-124 cm in thickness (Jackson 1934:6). Additionally, about 6-12 m west of Mound No. 2 are quantities of burned clay and daub, indicating a burned Caddo structure in this area. 
Table 1. Mound dimensions, L. A. Hale site.

\begin{tabular}{lccc}
\hline Mound No. & Length $(\mathrm{m})$ & Width $(\mathrm{m})$ & Height $(\mathrm{m})$ \\
\hline 1 & 44.8 & 21.3 & 3.8 \\
2 & 33.5 & 51.2 & 3.2 \\
3 & 13.1 & 10.7 & 0.8 \\
4 & 12.8 & 10.4 & 0.9 \\
5 & 14.0 & 12.2 & 0.9 \\
6 & 11.3 & 12.8 & 1.4 \\
\hline
\end{tabular}

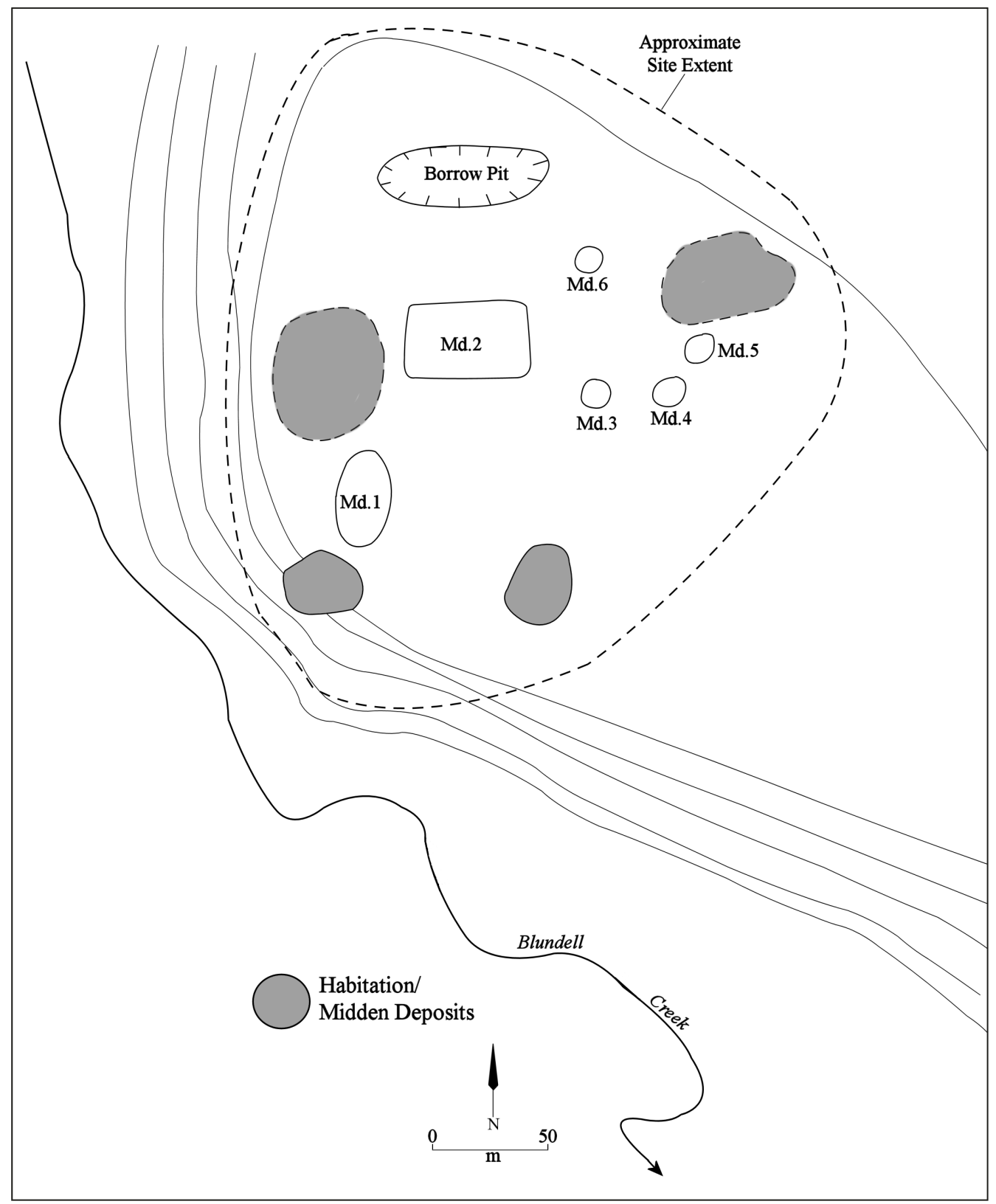

Figure 2. Map of the L. A. Hale site (after Thurmond 1990:Figure 24). 


\section{Mound No. 1}

The 1934 UT excavations in Mound No. 1 consisted of a $4.6 \mathrm{~m}$ wide trench that ran for $21.3 \mathrm{~m}$ eastwest through the mound (Jackson 1934:10). The excavations confirmed that this feature is indeed an artificially constructed earthen mound with basket-loaded clay and sand fill zones (Figure 3) to a depth of $3.78 \mathrm{~m}$ bs. Zones I-IV consisted of clays and sand mound fill deposits, and only Zone IV had much in the way of habitation debris (i.e., charcoal, ashes, animal bones, pottery sherds, and small mussel shells, Jackson 1934:19). Zone V is a dark brown sandy loam with a few pieces of charcoal, while Zone VI is a hard-packed yellow clayey sand with red clay lumps. Zones V and VI may represent a structural zone atop the original ground surface (Zone VII, a yellowish-red sandy soil), or on the first mound platform; the ash concentrations noted below are found primarily associated with Zones V, VI, and VII. These zones had considerable charcoal as well as more animal bones, pottery sherds, and mussel shell than any of the other Mound No. 1 zones (Jackson 1934:19). Zone VIII is described as undisturbed.

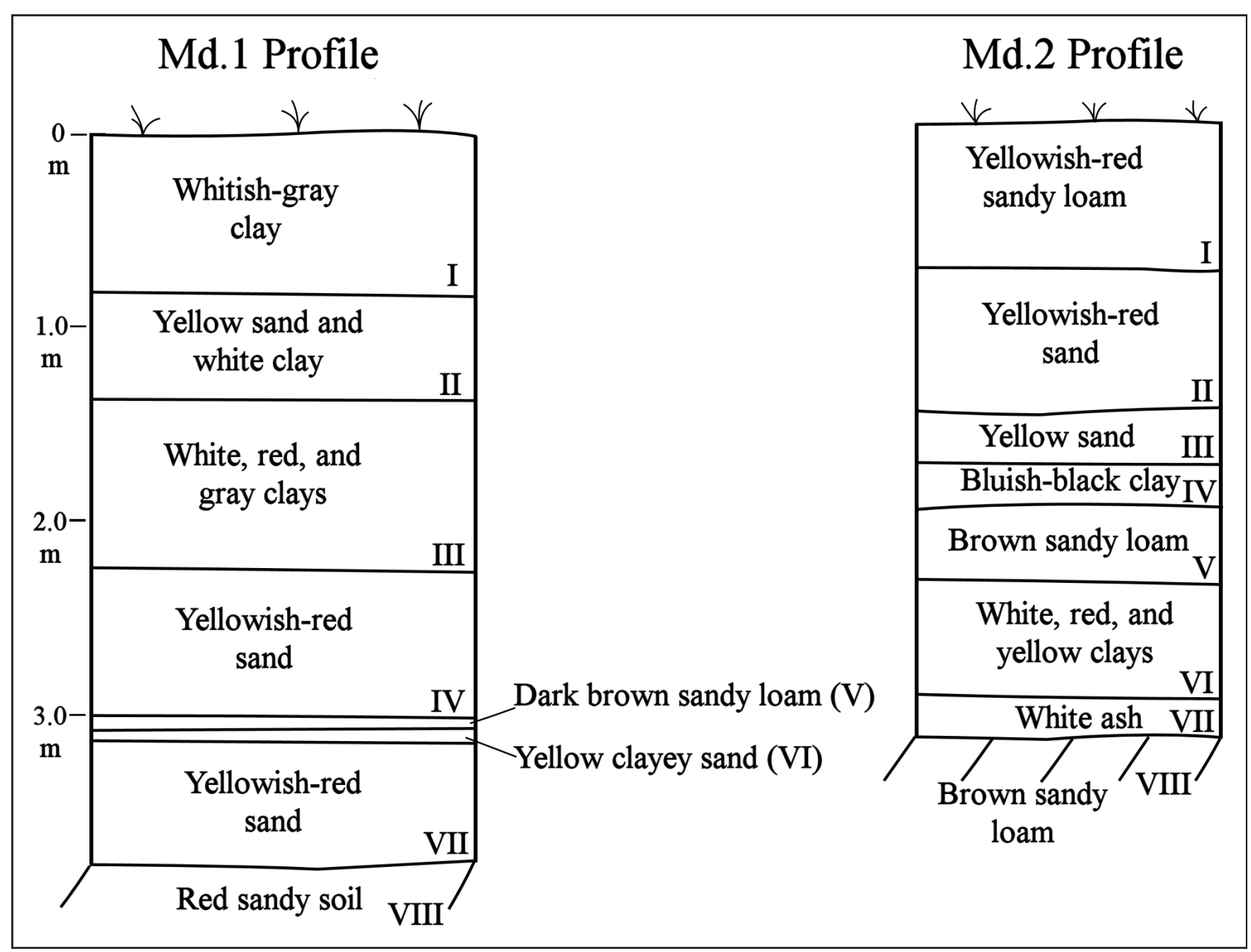

Figure 3. Schematic profiles of Mounds No. 1 and No. 2 at the Hale site.

Notable features identified in Mound No. 1 included:

- a $3.1 \times 1.8 \mathrm{~m}$ brown loam strata from $66-81 \mathrm{~cm}$ bs, with many small pieces of charcoal and pottery sherds; 
- a $2.0 \times 1.2 \mathrm{~m}$ long and wide ash zone (30-35 cm thick) near the center of the mound, at a depth of $1.57 \mathrm{~m}$ bs, suggesting a considerable and repeated accumulation of ash from nearby fires or burned structural deposits;

- a $1.42 \mathrm{~m}$ diameter pit or hearth at $2.03 \mathrm{~m}$ bs filled with a $2-13 \mathrm{~cm}$ thick hard-packed ash deposit that overlaid a 7.6-10 cm lens of brick-hard burned soil; a small portion of an engraved vessel was recovered in the burned soil (Jackson 1934:13-14);

- a deposit of ca. 100 mussel shells at a depth of $1.98 \mathrm{~m}$ in the western part of the trench (Jackson 1934:17);

- five other small concentrations of hard-packed ash and charcoal at depths of $2.89 \mathrm{~m}, 3.05 \mathrm{~m}$, $3.44 \mathrm{~m}$, and $3.50 \mathrm{~m}$ bs, with a few recovered human remains (teeth and phalange) with one concentration - a probable cremation - as well as animal bones and other occupational debris (mussel shells, charred acorns, etc.);

- and six scattered post holes (13-20 cm in diameter and $25-35 \mathrm{~cm}$ in depth) found between 2.28$3.60 \mathrm{~m}$ bs (Jackson 1934:31).

\section{Mound No. 2}

The UT work in Mound No. 2 consisted of a $1.8 \mathrm{~m}$ wide trench that was placed along a $12.2 \mathrm{~m}$ distance of its northwest edge (Jackson 1934:34). The mound appears to have been built over a burned house or temple floor marked by a ca. $20 \mathrm{~cm}$ thick zone of hard-packed ash (Zone VII in Mound No. 2, see Figure 3). Very little evidence of occupational debris was encountered in any of the Mound No. 2 zones (Jackson 1934:36).

Other test holes, ranging from 2.4-3.0 x 1.8-2.4 $\mathrm{m}$ in size, were excavated on three sides of Mound No. 2 (Jackson 1934:37). In the one test hole on the east side of the mound, evidence of burned structural deposits in the mound was suggested by the recovery of large pieces of burned red and yellow clay at $2.52 \mathrm{~m}$ bs.

\section{Mounds No. 3-5}

Test holes of an unspecified size and depth were excavated in these three small mounds. Mound No. 3 was built over a burned Caddo structure marked by a ca. $13 \mathrm{~cm}$ thick zone of charcoal overlying a zone of burned clay and daub. This feature extended for $10.1 \mathrm{~m}$ north-south and $5.8 \mathrm{~m}$ east-west (Jackson 1934:8). Mound No. 4 appears to have been a natural knoll with occupational refuse, while Mound No. 5 consists of a 30-66 cm thick midden deposit with pottery sherds, animal bones, a bone needle, mussel shells, etc.

\section{Material Culture Remains}

\section{Ceramic Sherds}

The focus of the ceramic analysis of the sherds from the Hale site is on the decorated sherds $(n=352)$. In particular, our concern was with the decorative methods and decorative elements present in both the utility wares and fine wares in the assemblage. The 43 plain rims and 1096 plain body (including three sandy paste body sherds and 12 shell-tempered body sherds) were not examined during the course of this study, nor were the 28 pieces of daub and/or burned clay (1986 UT Specimen Inventory forms for the Hale site). The plain to decorated sherd ratio in the assemblage is 3.24. 


\section{Use of Temper in Ceramic Vessel Manufacture}

The majority of the utility ware and fine ware vessel sherds at the Hale site are from grog-tempered vessels (ca. 76 percent). Nevertheless, a significant portion of these decorated wares were tempered with crushed and burned bones by ancestral Caddo potters, between 22.4-29.8 percent by ware (Table 2).

There is no significant difference between the wares in the proportion that was either grog or bone-tempered, although bone-tempered fine wares are more common in the ceramic assemblage.

Table 2. Use of bone temper in utility ware and fine ware sherds from the Hale site.

\begin{tabular}{lccc}
\hline Ware & $\begin{array}{c}\text { No. of sherds with } \\
\text { bone temper }\end{array}$ & No. of sherds & $\begin{array}{c}\text { Percent bone- } \\
\text { tempered }\end{array}$ \\
\hline Utility & 66 & 295 & 22.4 \\
Fine & 17 & 57 & 29.8 \\
Totals & 83 & 352 & 23.6 \\
\hline
\end{tabular}

\section{Decorated Sherds}

The decorated sherds from the Hale site in the TARL collections include 58 rim sherds and 294 body sherds (Table 3). About 84 percent of the sherds are from utility wares - wet paste decorations, primarily on jars - and the remainder are from fine wares decorated with engraved or red-slipped elements. The proportion of rims among the two wares are roughly the same: 74 percent from utility wares and 26 percent from fine wares. Factoring in the plain rims, approximately 43 percent of the rims in the Hale site ceramic assemblage are from plain wares (from carinated bowls, simple bowls, and jars), indicating a considerable proportion of plain wares in the Caddo ceramics made and used at the site.

Table 3. Decorated sherds from the Hale site.

\begin{tabular}{lrrr}
\hline Decorative Method & Rim & Body & N \\
\hline Utility Ware & & & 7 \\
& - & 7 & 4 \\
Appliqued & - & 4 & 1 \\
Brushed & 1 & - & 113 \\
Brushed-Incised & & 83 & 1 \\
Incised & 1 & - & 15 \\
Incised-Appliqued & 3 & 12 & 1 \\
Incised-Punctated & - & 1 & 8 \\
& - & 8 & 109 \\
Punctated, Cane & 5 & 104 & 32 \\
Punctated, Large Circular & 3 & 1 & 1 \\
Punctated, Fingernail & - & & \\
Punctated, Tool & & &
\end{tabular}


Table 3. Decorated sherds from the Hale site, cont.

\begin{tabular}{lrrr}
\hline Decorative Method & Rim & Body & N \\
\hline Neck banded & - & 3 & 3 \\
Subtotal & 43 & 252 & 295 \\
Fine Ware & & & \\
Engraved & 14 & 31 & 45 \\
Engraved-Punctated & - & 1 & 1 \\
Red Slipped & 1 & 10 & 11 \\
Subtotal & 15 & 42 & 57 \\
\hline Totals & 58 & 294 & 352 \\
\hline
\end{tabular}

\section{Appliqued}

The seven appliqued body sherds have the following decorative elements: a straight appliqued ridge $(\mathrm{n}=3)$; a straight appliqued fillet $(\mathrm{n}=1)$; a straight appliqued fillet and an adjacent appliqued node $(\mathrm{n}=1)$; opposed appliqued ridges and an adjacent appliqued node ( $n=1$, Figure $4 \mathrm{~b})$; and a curvilinear set of appliqued fillets $(n=1$, Figure 4c). These appliqued decorations apparently occur on the body of utility ware jars, in several cases probably as vertical elements that created plain body panels. Those sherds with appliqued ridges and fillets with an adjacent appliqued node, as well as curvilinear fillets, are probably part of more complex decorative motifs, perhaps like those on Harleton Appliqued jar bodies (see Suhm and Jelks 1962:Plate 33). These latter sherds may be associated with other Late Caddo, Titus phase, ceramics found at the Hale site.

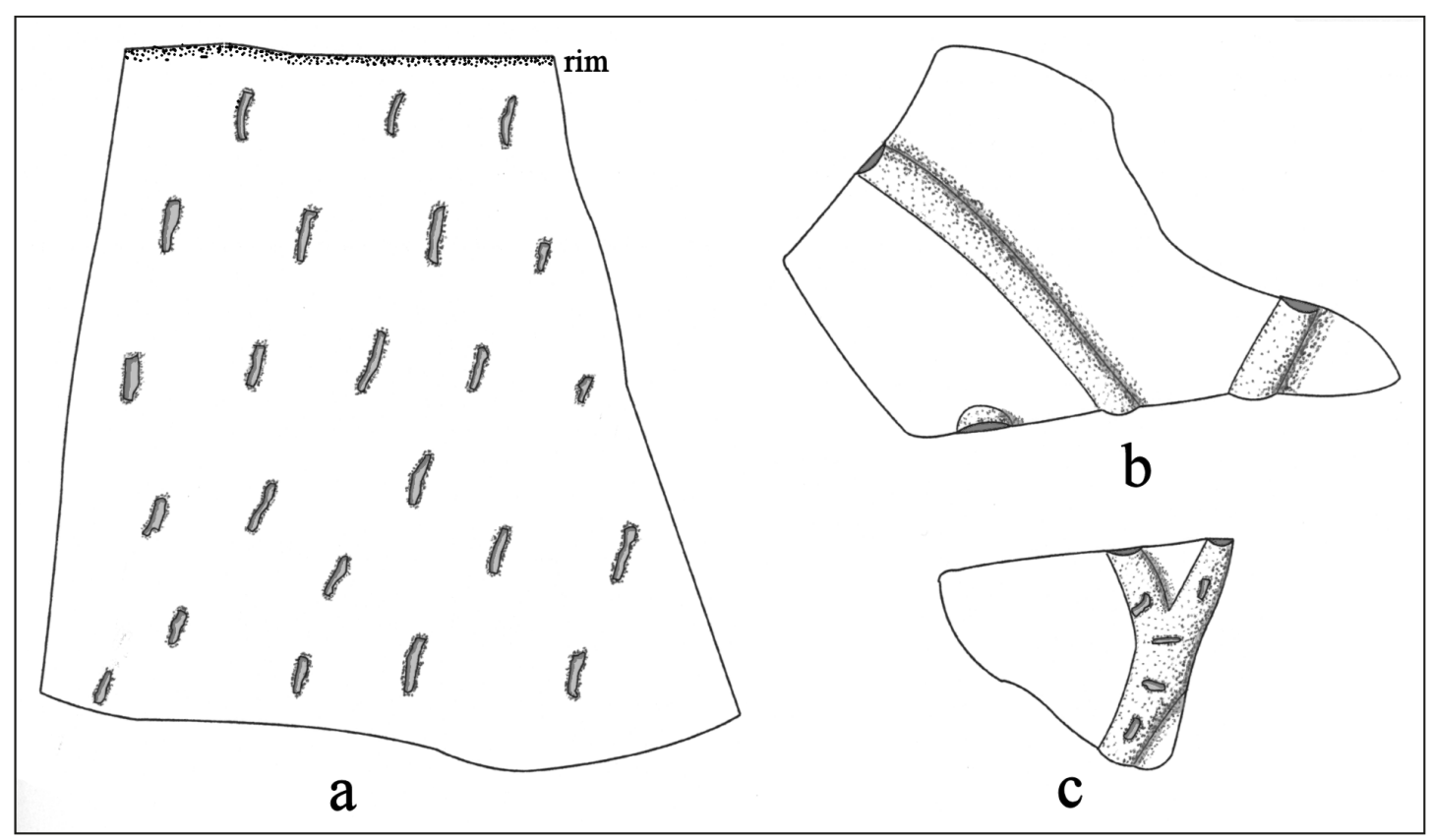

Figure 4. Appliqued and fingernail punctated rim and body sherd decorative elements: a, fingernail punctated; b-c, appliqued. 


\section{Brushed}

All four of the brushed sherds from the Hale site are from the body of jars. The brushing orientation is parallel, suggesting that the brushing was actually oriented vertically on the vessel body; they may be from Bullard Brushed or Karnack Brushed-Incised jars, and they are part of a small collection of Late Caddo, Titus phase sherds in the assemblage.

\section{Brushed-Incised}

The one brushed-incised sherd is from a jar with a direct rim and a flat lip. It has horizontal brushing marks and incised lines on the rim of the vessel.

\section{Incised}

The rim sherds with incised decorative elements are predominantly from Dunkin Incised jars with diagonal or diagonal opposed lines $(n=16)$ and cross-hatched elements $(n=1)$, Dunkin Incised bowls with vertical incised lines $(n=1)$, and bowls and jars with horizontal incised lines $(n=12)$ (Table 4 and Figure 5b-c). One bone-tempered diagonal incised rim has a decorated collar around the vessel. The horizontal incised rims include one from a Coles Creek Incised, var. unspecified bowl with a single broad and overhanging line (Figure 5a) well down the vessel rim (direct with a flat lip, no lip line, and the exterior surface is also burnished), and 11 other rims that may be from Davis Incised bowls; these do not have overhanging incised lines.

Table 4. Decorative elements on incised rim and body sherds from the Hale site.

\begin{tabular}{lrrr}
\hline Decorative element & Rim & Body & N \\
\hline Cross-hatched lines & - & 11 & 11 \\
Cross-hatched and horizontal lines & 1 & - & 1 \\
Cross-hatched and parallel lines & - & 1 & 1 \\
Diagonal lines & 14 & 1 & 15 \\
Diagonal opposed lines & 2 & 4 & 6 \\
Horizontal lines & 11 & - & 11 \\
Horizontal line, overhanging & 1 & 3 & 1 \\
Horizontal and diagonal lines & - & 2 & 3 \\
Horizontal and vertical lines & - & 57 & 2 \\
Parallel lines & - & 2 & 57 \\
Parallel lines, overhanging & - & 2 & 3 \\
Vertical lines & 1 & 83 & 113 \\
\hline Totals & 30 & & 2 \\
\hline
\end{tabular}

Two body sherds with overhanging parallel incised lines (see Table 4) are likely also from Coles Creek Incised vessels. The many cross-hatched incised body sherds are probably lower rim sherds from Canton Incised and Dunkin Incised bowls or carinated bowls, although no carina were recognized on any of them. 


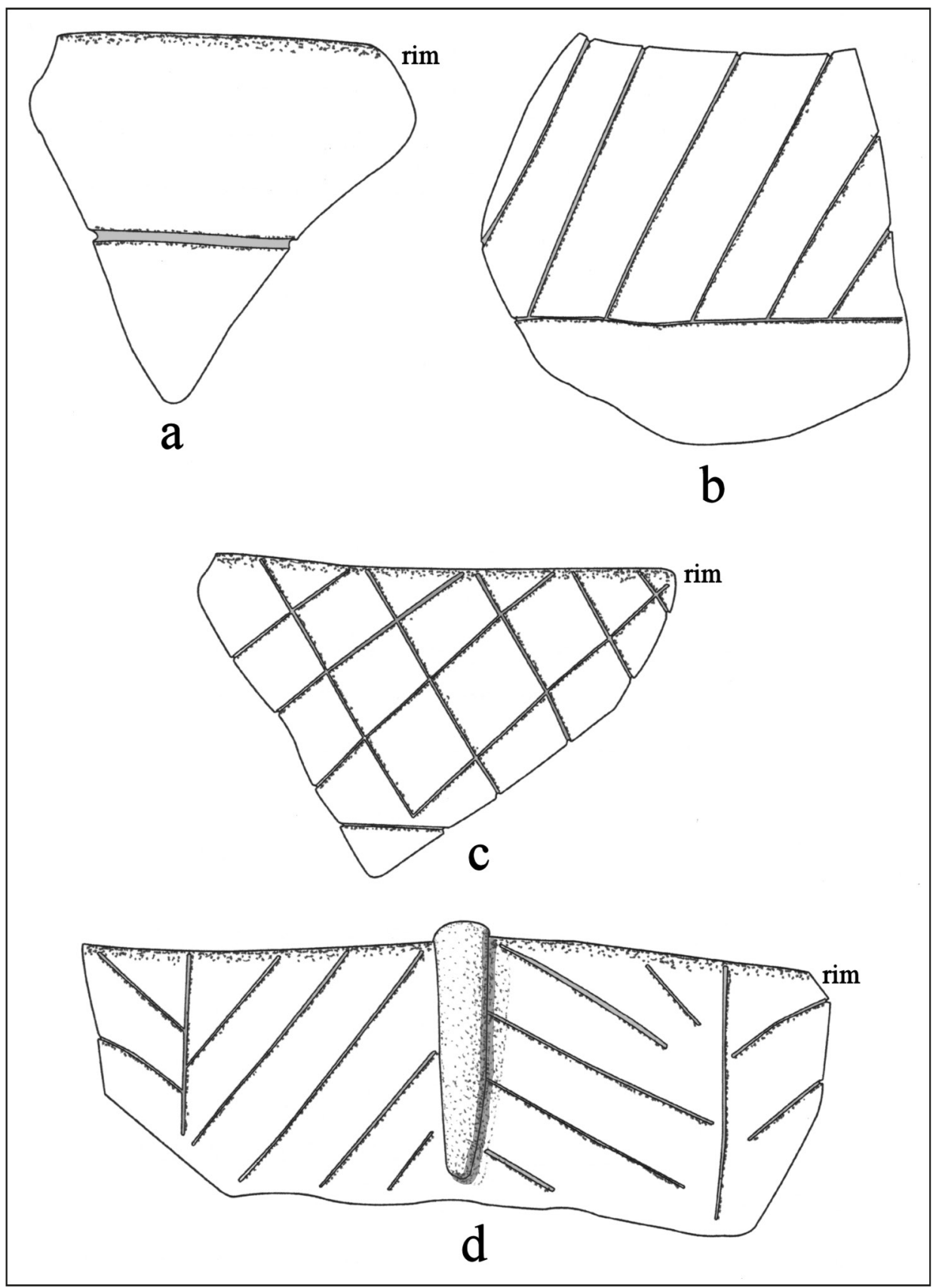

Figure 5. Incised and Incised-appliqued rim and lower rim sherd decorative elements: a-c, incised; d, incised-appliqued.

\section{Incised-Appliqued}

There are three rim sherds in Mound No. 1 from the same Dunkin Incised vessel that have incised-appliqued decorative elements. The rim is divided into a number of panels by vertical incised lines, and the panels are filled with diagonal opposed incised lines (chevron) (see Figure 5d). In at least one instance, the vertical incised line is replaced by a vertical appliqued ridge that ends in a rim tab. There probably were four appliqued ridges and rim tabs around the vessel rim. 


\section{Incised-Punctated}

The incised-punctated sherds in the Hale site ceramic assemblage typically feature incised zones and bands of various shapes that are filled with either cane punctations, fingernail punctates, or tool punctates (Table 5). They include incised circles (probably from a Crockett Curvilinear Incised vessel), triangles (Figure 6b-c) filled with punctations, curvilinear zones (Figure 6e), and horizontal bands filled with crescent-shaped fingernail punctations (Figure 6a). The latter is from a Weches Fingernail Impressed, var. Weches jar (see Stokes and Woodring 1981:Figures 22n-q and 23a). This particular sherd was found between 231-356 cm bs in Mound No. 1 deposits.

Table 5. Decorative elements on incised-punctated rim and body sherds from the Hale site.

\begin{tabular}{|c|c|c|c|}
\hline Decorative element & Rim & Body & $\mathrm{N}$ \\
\hline cane punctates in incised circle & - & 1 & 1 \\
\hline fingernail punctates between incised lines/bands & - & 1 & 1 \\
\hline $\begin{array}{l}\text { fingernail punctated zone below diagonal opposed and } \\
\text { horizontal incised lines }\end{array}$ & - & 1 & 1 \\
\hline fingernail punctated zone below horizontal incised lines & - & 3 & 3 \\
\hline fingernail punctated zone and adjacent incised line & - & 1 & 1 \\
\hline tool punctated row below horizontal incised line & 1 & - & 1 \\
\hline tool punctated row and adjacent straight incised line & - & 1 & 1 \\
\hline tool punctated zone in incised triangle & 2 & 1 & 3 \\
\hline tool punctated zone and adjacent incised line & - & 1 & 1 \\
\hline tool punctated zone and adjacent parallel lines & - & 1 & 1 \\
\hline tool punctated zone and curvilinear incised lines & - & 1 & 1 \\
\hline Totals & 3 & 12 & 15 \\
\hline
\end{tabular}

Other incised-punctated sherds have horizontal or diagonal opposed incised lines on what appears to be the lower rim and tool or fingernail punctated rows or zones on the vessel body (see Figure 6df). These are likely from Early Caddo style Dunkin Incised and Kiam Incised jars (see Suhm and Jelks 1962:Plates 19g and 45b-e).

\section{Punctated, Cane}

The one cane punctated body sherd has more than one row of cane punctations on it. These punctations occur at the rim-body juncture of a utility ware jar.

\section{Punctated, Large Circular}

These body sherds have rows of large circular punctations as the sole decorative element on utility ware vessels. 


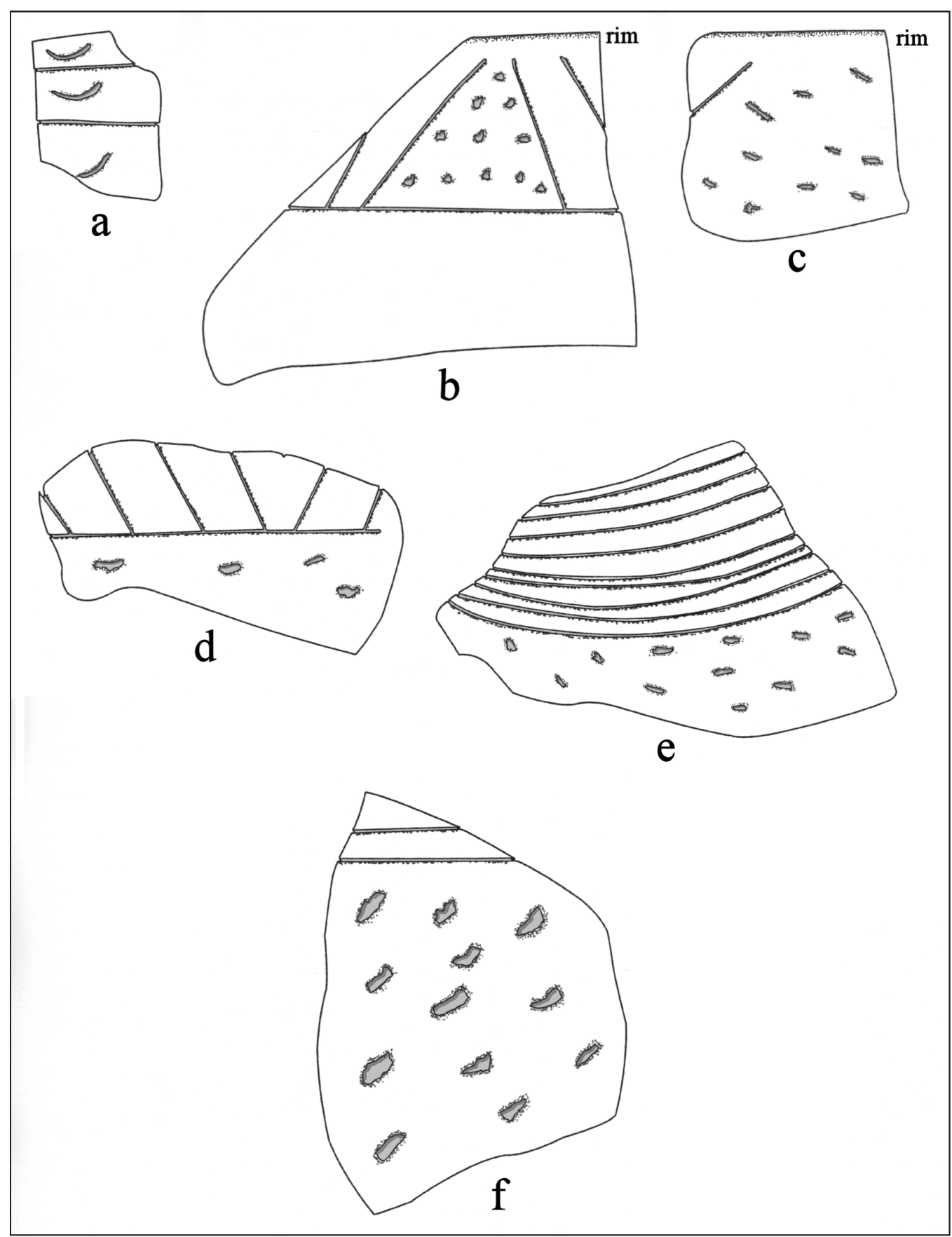

Figure 6. Incised-punctated rim and body sherd decorative elements: a, d-f, body sherds; b-c, rim sherds.

\section{Punctated, Fingernail}

Utility ware vessels at the Hale site are commonly decorated with rows of fingernail punctations (see Table 3). More than 72 percent of all the punctated rim and body sherds in the assemblage have fingernail punctated decorations (see Figure 4a), and they out number vessels with tool punctates by more than a 3:1 ratio (Table 6). Rims have rows of fingernail punctations, as do body sherds. One body sherd has opposed rows of fingernail punctates. 
Table 6. Decorative elements on fingernail and tool punctated rim and body sherds from the Hale site.

\begin{tabular}{lccr}
\hline Decorative element & Rim & Body & $\mathrm{N}$ \\
\hline fingernail punctated rows & 5 & 102 & 107 \\
fingernail punctated, opposed rows & - & 1 & 1 \\
tool punctated rows & 3 & 30 & 33 \\
\hline Totals & 8 & 133 & 141 \\
\hline
\end{tabular}

\section{Punctated, Tool}

Tool punctated sherds comprise about 22 percent of the sherds with punctated decorative elements (see Tables 3 and 6). Both rims and bodies of utility ware vessels have rows of tool punctations.

\section{Punctated, Tool-Fingernail}

One body sherd has both fingernail and tool punctated elements. This consists of alternating rows of tool or fingernail punctations across the vessel surface.

\section{Neck banded}

The three neck banded body sherds are from La Rue Neck Banded jars with horizontal rows of neck bands that encircle the rim. These neck banded sherds, along with a few brushed sherds and Ripley Engraved rim sherds, as discussed elsewhere in this section, constitute the sole evidence for use of the Hale site after ca. A.D. 1430, in the Titus phase of the Late Caddo period.

\section{Engraved}

The Early Caddo period engraved sherds from the Hale site include sherds from bowls and carinated bowls $(n=32)$ (Table 7$)$ as well as bottles $(n=10)$. The fine ware bowl and carinated bowl sherds in the decorated sherd assemblage are primarily from Holly Fine Engraved (Figure 7a-c, g-h) and Spiro Engraved (Figure 7e-f) vessels with fine line decorative elements. The Spiro Engraved sherds are from Zone IV in Mound No. 1, recovered at a depth of ca. $227 \mathrm{~cm}$ bs.

Table 7. Decorative elements on Early Caddo engraved bowl and carinated bowl rim and body sherds from the Hale site.

\begin{tabular}{lccc}
\hline Decorative element & Rim & Body & N \\
\hline cross-hatched zone & - & $3^{*}$ & 3 \\
diagonal lines & 2 & 3 & 5 \\
diagonal opposed, fine line & 1 & 1 & 2 \\
diagonal opposed and excised triangles, fine line & 2 & 1 & 3 \\
horizontal lines, multiple & 3 & - & 3 \\
horizontal and curvilinear lines, effigy bowl & 1 & - & 1 \\
opposed lines, fine line & - & 1 & 1 \\
opposed curvilinear, fine line & - & 1 &
\end{tabular}


Table 7. Decorative elements on Early Caddo engraved bowl and carinated bowl rim and body sherds from the Hale site, cont.

\begin{tabular}{lccc}
\hline Decorative element & Rim & Body & N \\
\hline parallel lines, fine line & - & 1 & 1 \\
parallel lines & - & 4 & 4 \\
straight line & - & 2 & 2 \\
straight and curvilinear lines & - & 1 & 3 \\
vertical lines & 2 & 1 & 2 \\
vertical and curvilinear, fine lines & 2 & - & 32 \\
\hline Totals & 13 & 19 & \multirow{2}{*}{} \\
\hline
\end{tabular}

*one interior/exterior red-slipped

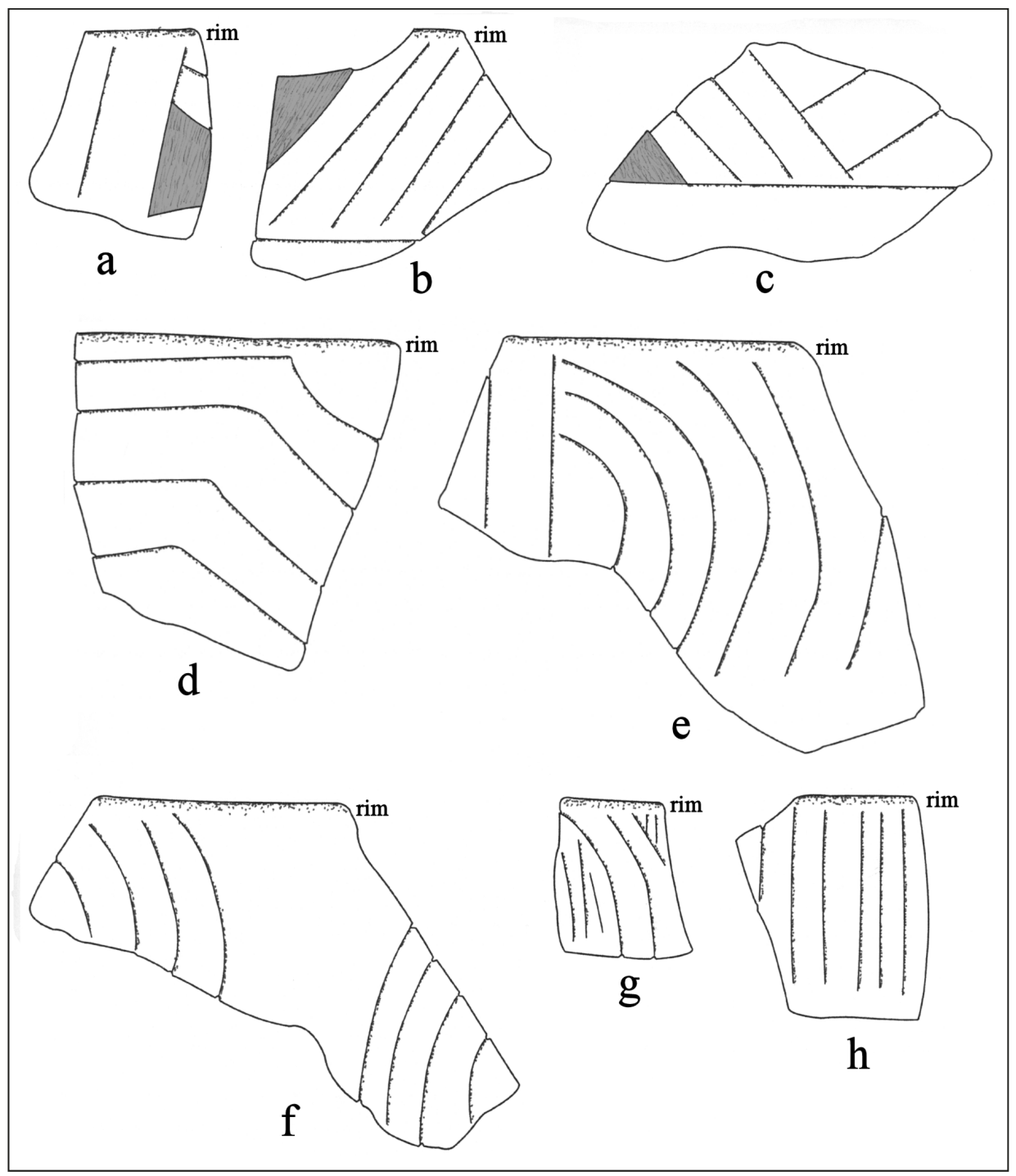

Figure 7. Engraved rim and lower rim sherd decorative elements. 
One rim is from a engraved variety of East Incised bowl with opposed tabs built out from the side of the lip (see Suhm and Jelks 1962:Plate 21j), and with horizontal and curvilinear engraved lines; the curvilinear lines dip under the lip tabs (see Figure 7d). The rims with horizontal engraved lines (see Table 7) are from Hickory Engraved bowls. The three body sherds with cross-hatched engraved zones are not identifiable as a current Caddo ceramic fine ware type.

There are also four sherds from Late Caddo, Titus phase, Ripley Engraved vessels in the Hale site assemblage (they are not included in Table 7). This includes a rim (direct, with a rounded, exterior folded lip) from a carinated bowl with a slanting scroll element and three lower rim sherds with scroll elements.

About 24 percent of the engraved sherds from the Early Caddo component at the Hale site are from bottles (Table 8). Most, if not all, of these sherds are from Holly Fine Engraved and Spiro Engraved bottles with curvilinear (probably part of larger concentric and spiral motifs) and opposed fine line elements (Figure 8a-b). Two bottle sherds have curvilinear fine line engraved elements, with one line more pronounced (i.e., deeper and wider) than the others (Figure 8c). This latter is a common treatment on Holly Fine Engraved bottles (Suhm and Jelks 1962:77). None of the bottle sherds are from vessels where a red or white clay pigment was rubbed in the engraved lines.

Table 8. Decorative elements on Early Caddo engraved and engraved-punctated bottle sherds from the Hale site.

Decorative element N N

curvilinear fine line $\quad 2$

curvilinear fine line, one line more pronounced than others $\quad 2$

curvilinear lines $\quad 1$

diagonal opposed and curvilinear fine line $\quad 2$

$\begin{array}{ll}\text { excised zone, narrow and straight } & 1\end{array}$

opposed fine line 1

opposed fine lines and bands/triangular zones with punctations 1

Totals

10

\section{Engraved-Punctated}

The one engraved-punctated body sherd (see Table 8) is from a bottle (see Figure 8d), probably a sherd from a Spiro Engraved bottle (see Suhm and Jelks 1962:147 and Plate 74b, f, i). The sherd from the Hale site has fine opposed engraved lines between bands and triangular zones with one or more rows of excised punctations.

\section{Red Slipped}

The 11 red slipped sherds comprise approximately 20 percent of the fine ware sherds in the Hale ceramic sherd assemblage; they are from Mound No. 1 and Mound No. 5 excavations. The one rim (everted, with a rounded lip) is from a carinated bowl that has been slipped on both interior and exterior surfaces. A second carinated bowl sherd has only an exterior red slip. Five other body sherds have both an interior and exterior red slip, while four have only an exterior red slip; none of the red slipped sherds are from bottles. 


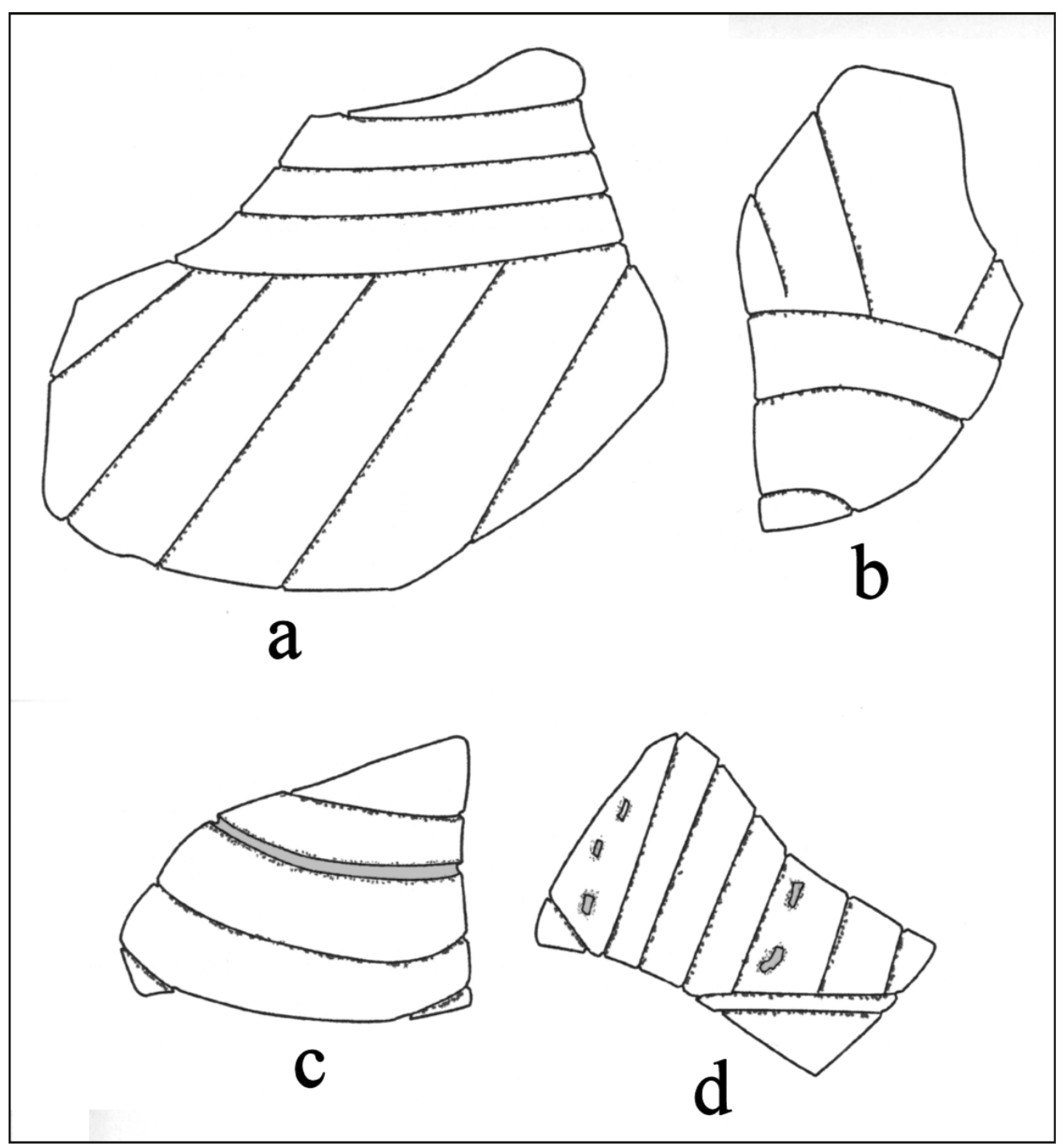

Figure 8. Engraved bottle body sherd decorative elements: a-c, engraved; d, engraved-punctated.

\section{Plain Base Sherds}

There are 51 plain base sherds in the ceramic assemblage; each are from thick and flat-based vessels. Approximately 18 percent of the base sherds are from bone-tempered vessels.

\section{Ceramic Pipe Sherds}

There are two pipe sherds in the assemblage. The first, from Mound No. 1, is a sherd from the stem of a bone-tempered Red River long-stemmed pipe (see Hoffman 1967). This stem piece has an exterior diameter of $11.2 \mathrm{~mm}$ and an interior hole diameter of $5.6 \mathrm{~mm}$. The other sherd appears to be the basal section of a bone-tempered platform pipe; the bowl and much of the platform is missing. The remaining piece is $50.7+\mathrm{mm}$ in length, $26.5 \mathrm{~mm}$ in width, and $16.0 \mathrm{~mm}$ in width. 


\section{Modeled Clay Fragment}

This modeled piece of clay, possibly a figurine fragment, is ovoid-shaped and poorly smoothed with a single short $(20 \mathrm{~mm})$ rectangular groove on one side of the piece. It is $55.7 \mathrm{~mm}$ in length, $45.0 \mathrm{~mm}$ in width, and $21.8 \mathrm{~mm}$ in thickness.

\section{Chipped Stone Tools}

The chipped stone tools from the Hale site in the UT collections include one Late Paleoindian lanceolate point, 40 dart points and preforms, seven arrow points, and a finished biface. The Late Paleoindian point is made from a non-local gray chert, and it has a resharpened blade and a laterally ground stem.

The typologically identifiable dart points include Middle Archaic to Woodland period forms, including Calf Creek ( $\mathrm{n}=1$, made from a non-local brownish-gray chert), Morrill ( $\mathrm{n}=1$, local quartzite), Delhi ( $n=1$, local chert), Wells ( $n=2$, local quartzite), Yarbrough ( $n=3$, local quartzite), Ellis ( $n=1$, local quartzite), Kent ( $n=7$, six of local quartzite and petrified wood, and one non-local gray chert), and 18 Gary points (local quartzite and brown chert); most of the Gary points have narrow stems, suggesting more than an occasional use of the site during the Woodland period. Only 8 percent of the dart points are made from non-local chert raw materials, and the majority of those made from local raw materials are on quartzite. There are also two Gary preforms (quartzite and dark brown chert) in the assemblage, as well as two point blades, and two straight stemmed forms of unidentified type.

In Mound No. 1, the dart points were found between $218-355 \mathrm{~cm}$ bs, in Zone IV to Zone VII deposits (i.e., in and below the mound). Those dart points found in the mound were likely incorporated into mound fill from pre-mound habitation deposits/sediments at the site that were gathered into basket loads for mound construction by ancestral Caddo peoples.

The arrow points include a blade fragment, four Alba points with straight stems, and two points with expanding stems and corner notches. About 71 percent of the arrow points are made from locally available quartzite or brown chert, and the other 29 percent are made from non-local gray chert.

The finished biface, possibly a knive, is a fragment made from a non-local gray chert. The blade has been resharpened and serrated.

\section{Ground Stone Tools}

The one celt from the Hale site was found on the surface during the UT work. The chipped and polished celt is made from Ouachita Mountains greenstone, and has a chipped bit (Figure 9) as well as a large spall or flake removal that extends from the bit almost to the butt end. The celt is $131.6 \mathrm{~mm}$ in length, $53.6 \mathrm{~mm}$ in width, and $31.5 \mathrm{~mm}$ in thickness; the bit width is $53.0 \mathrm{~mm}$.

Additionally in the Hale site artifact assemblage, there is a celt spall or piece of debris that had been chipped from a finished and polished celt. This piece of debris is also a Ouachita Mountains greenstone material.

\section{Quartz Crystal}

There is a single quartz crystal fragment in the Hale site artifact assemblage. The fragment is $21 \mathrm{x}$ $13.5 \mathrm{~mm}$ in length and width. 


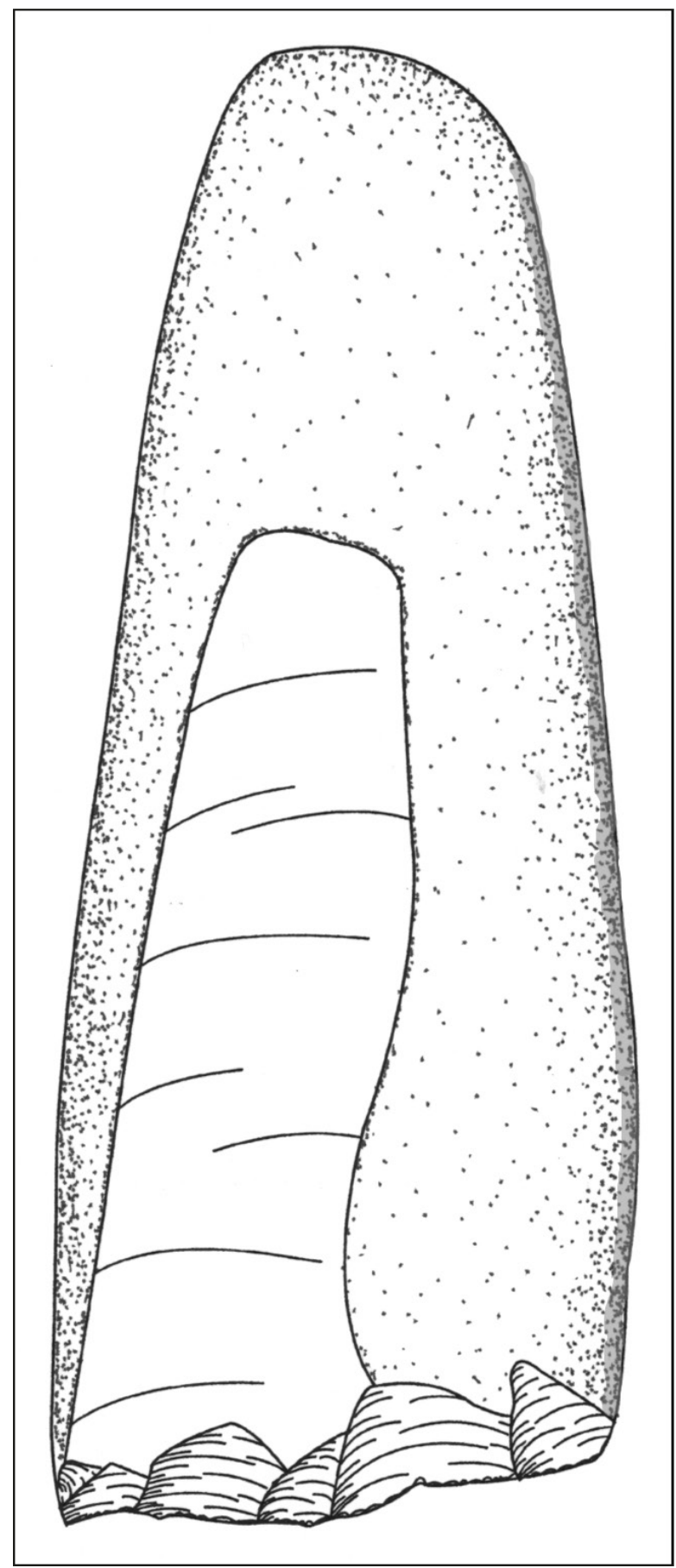

Figure 9. Ground stone celt from the Hale site.

\section{Pigments}

There are 21 pebble and cobble-sized pieces of stones or clay used as pigments. They include kaolin $(n=15)$, glauconite $(n=3)$, hematite $(n=3)$, and limonite $(n=1)$. They were recovered from the surface, in non-mound midden deposits, and at various depths $(234-266 \mathrm{~cm}$ bs in Zone IV and $332 \mathrm{~cm}$ bs in Zone VII) in and below Mound No. 1. 


\section{Bone Tools}

There are three bone tools in the Hale artifact assemblage, two from Mound No. 1 excavations and the other from Mound No. 5. The first of the Mound No. 1 bone tools is the distal end of a worked/polished deer bone punch or awl (Figure 10b). The fragment is $84.3+\mathrm{mm}$ in length and $11.0 \mathrm{~mm}$ in width; it was recovered in the lower part of Zone IV, at $295 \mathrm{~cm}$ bs. The second bone tool is a deer ulna awl with a broken working end (Figure 10c). This broken bone tool, $92.0 \mathrm{~mm}+$ in length and $31.0 \mathrm{~mm}$ in width, was found in Zone III, at a depth of $175 \mathrm{~cm}$ bs.

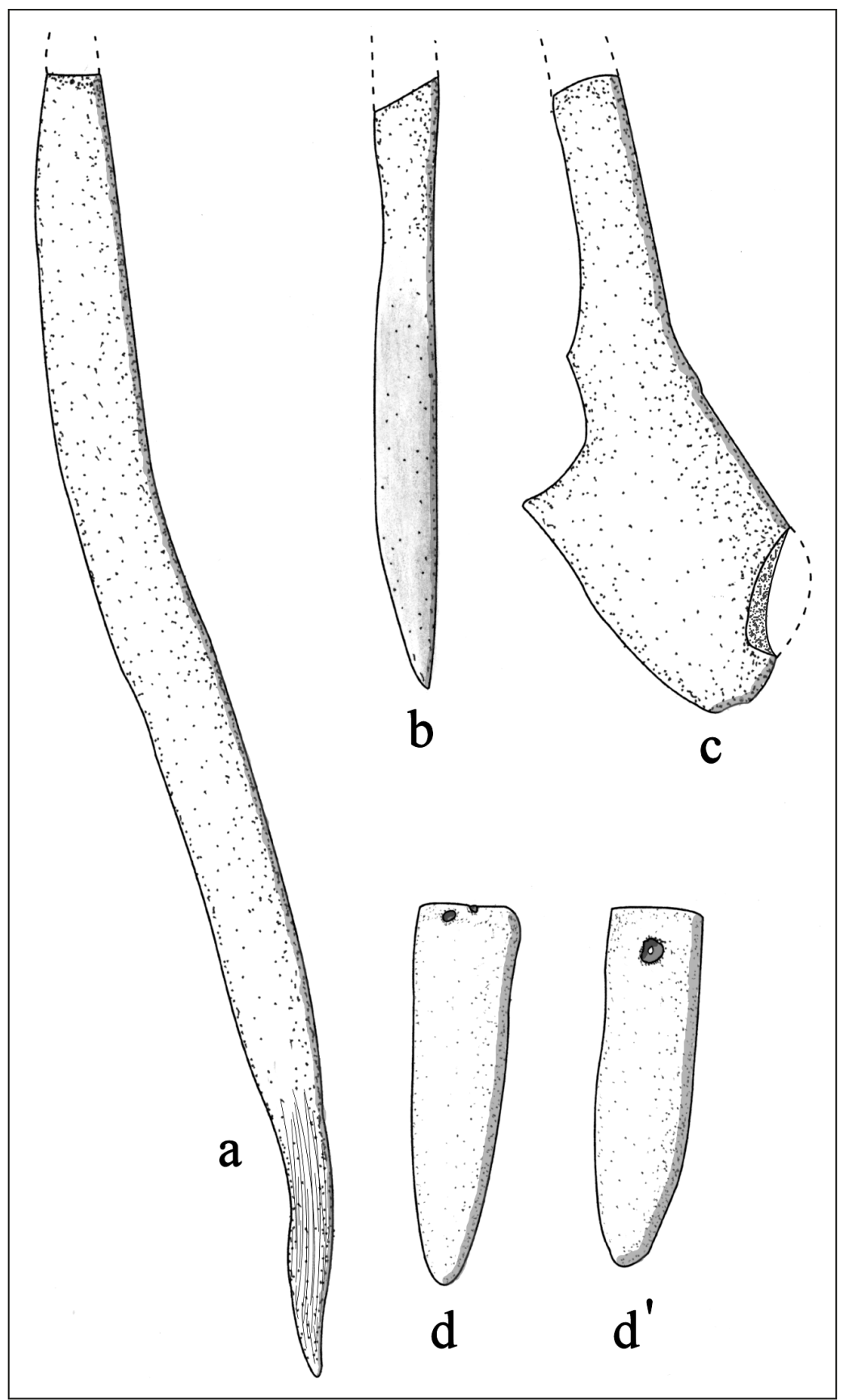

Figure 10. Bone tools and alligator tooth pendant: a-c, bone tools; d-d', alligator tooth pendant. 
The bone tool from Mound No. 5 has a pointed working end with scratches and striations, and may have been used as an awl or punch (see Figure 10a). The tool is $185.5+\mathrm{mm}$ in length, $15.0 \mathrm{~mm}$ in width, and $5.0 \mathrm{~mm}$ in thickness. This tool was recovered at a depth of $25 \mathrm{~cm}$ bs.

\section{Alligator Tooth Pendant}

The alligator tooth pendant (see Figure 10d-d') was recovered at a depth of $249 \mathrm{~cm}$ bs, in Zone IV of Mound No. 1. The tooth has drilled holes on both sides to allow the pendant to be suspended on a necklace, and these range from 2.0-5.6 $\mathrm{mm}$ in diameter. The pendant is $55.0 \mathrm{~mm}$ in length and $13.9 \mathrm{~mm}$ in width. 


\section{Chapter 3, Archaeological Investigations at the George L. Keith Site (41TT11)}

The George L. Keith site (41TT11) is located on a terrace remnant and the floodplain of Hart Creek, a southward-flowing tributary to Big Cypress Creek (Figure 11); the creek channel lies well west of the mound (Brown 1971a:2). The one mound at the site was trenched by UT in 1934, led by archaeologist (and later renowned anthropologist) Walter R. Goldschmidt, exposing a series of sub-mound and mound platform structures, several small associated midden deposits, as well as an outdoor activity area marked by post holes, pits, and concentrations of ash and charcoal (Goldschmidt 1934, 1935; Thurmond 1990:184).

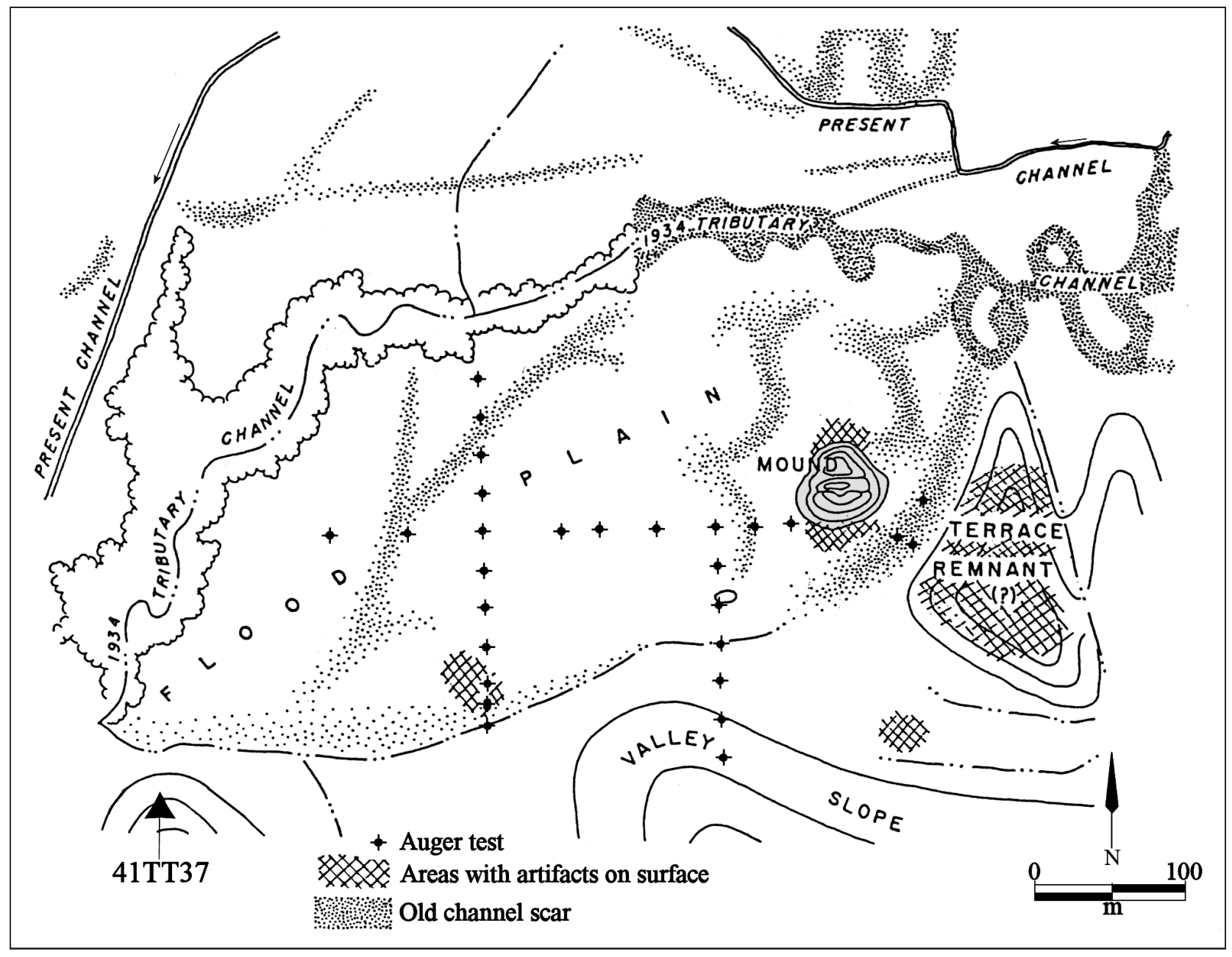

Figure 11. The mound at the George $\mathrm{L}$. Keith site, other areas with occupational debris, the terrace remnant where the Titus phase cemetery is located, and 1971 auger test locations (redrawn from Brown 1971a).

The one mound at the Keith site stood $4.6 \mathrm{~m}$ in height in 1934, and was approximately $48.7 \mathrm{x} 73 \mathrm{~m}$ in width and length, but may have originally stood at least $5.5 \mathrm{~m}$ tall (Goldschmidt 1934:1, 1935:97). The UT work consisted primarily of excavating a ca. $3.6 \mathrm{~m}$ wide trench east-west for a distance of $45.7 \mathrm{~m}$ through the mound; this trench was widened when a series of post holes were found in sub-mound midden deposits. This trench also encountered a black midden deposit beneath the mound itself, where animal bones were abundant (Goldschmidt 1934:28), followed by layers of sandy and clayey loam mound fill intermixed with midden debris, perhaps in two or more stages. Excavations into the sub-mound midden deposit identified 
post holes and other features at ca. $3.6 \mathrm{~m}$ below the surface (Figure 12). They were exposed underneath thin layers of black carbonaceous material (1-5 mm thick), ash, yellow clay $(5 \mathrm{~cm}$ thick), and sand $(6.3-9 \mathrm{~cm}$ thick), with the top of the post holes identified in a second underlying black layer (Goldschmidt 1934:8). These deposits indicate that the Caddo structure that was built in the midden deposits was burned down, probably deliberately, before it was capped with clay, structural debris, and the beginning mound fill zones.

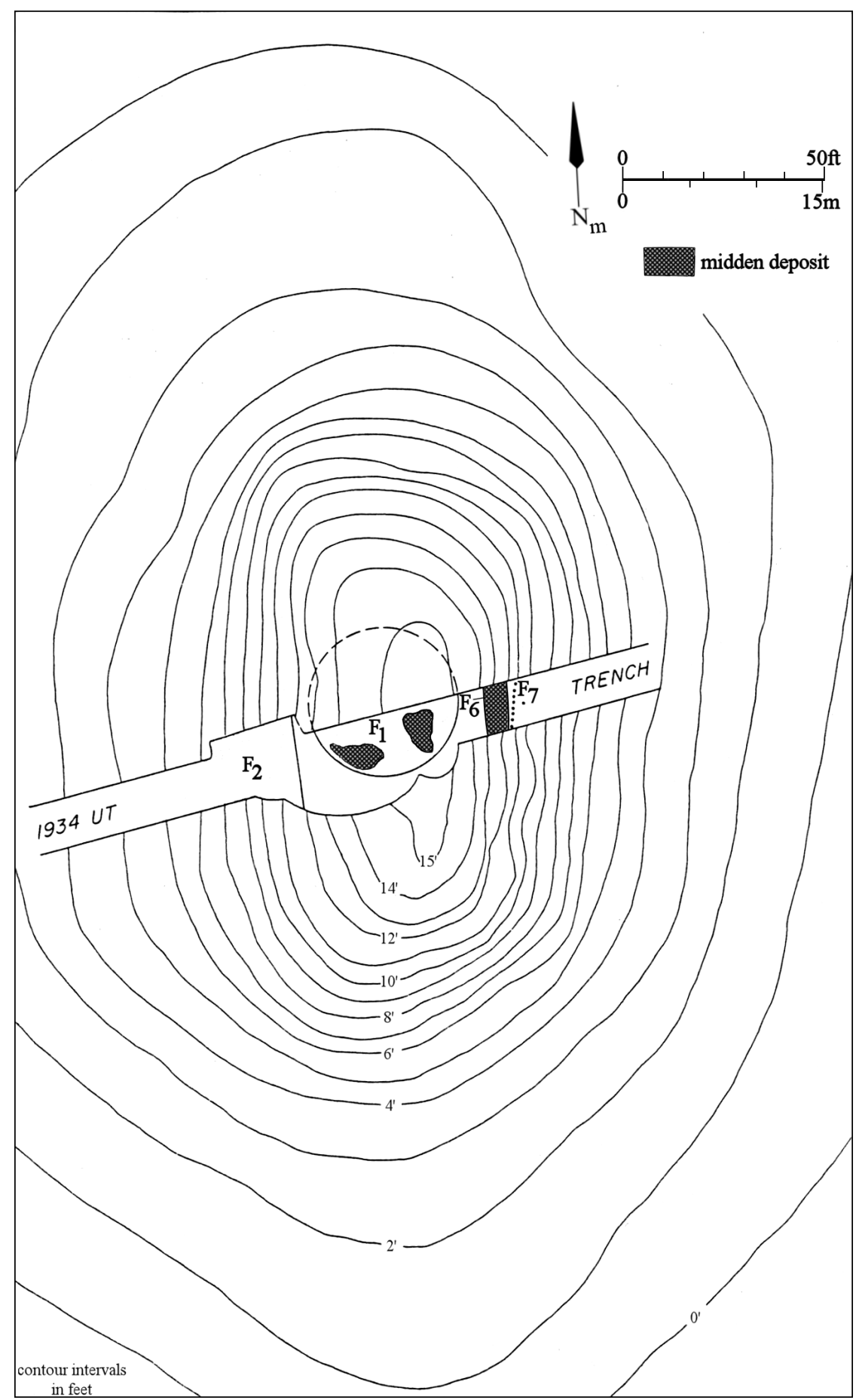

Figure 12. Features and post holes exposed in the sub-mound midden deposits in the 1934 trench cutting through the Keith mound (Redrawn from Brown 1971a). 
These features include several sets of post holes, including portions of a circular structure post hole pattern (Feature 1) as well as associated internal posts and small midden areas, two north-south rows of posts (Features 2 and 7) a few meters east and west of Feature 1, that are between 2.5-6.7 m long, that may mark a wooden post enclosure around the structure, midden deposits (Features 3 and 6), and several $0.6 \mathrm{~m}$ diameter pit features (Features 4 and 5) (Figure 13) that originated in sub-mound contexts in the western portion of the trench (Goldschmidt 1934:15). The circular structure is estimated to be approximately $9 \mathrm{~m}$ in diameter. A total of 191 post holes were recorded during the UT work (Goldschmidt 1934:20, 1935:98).

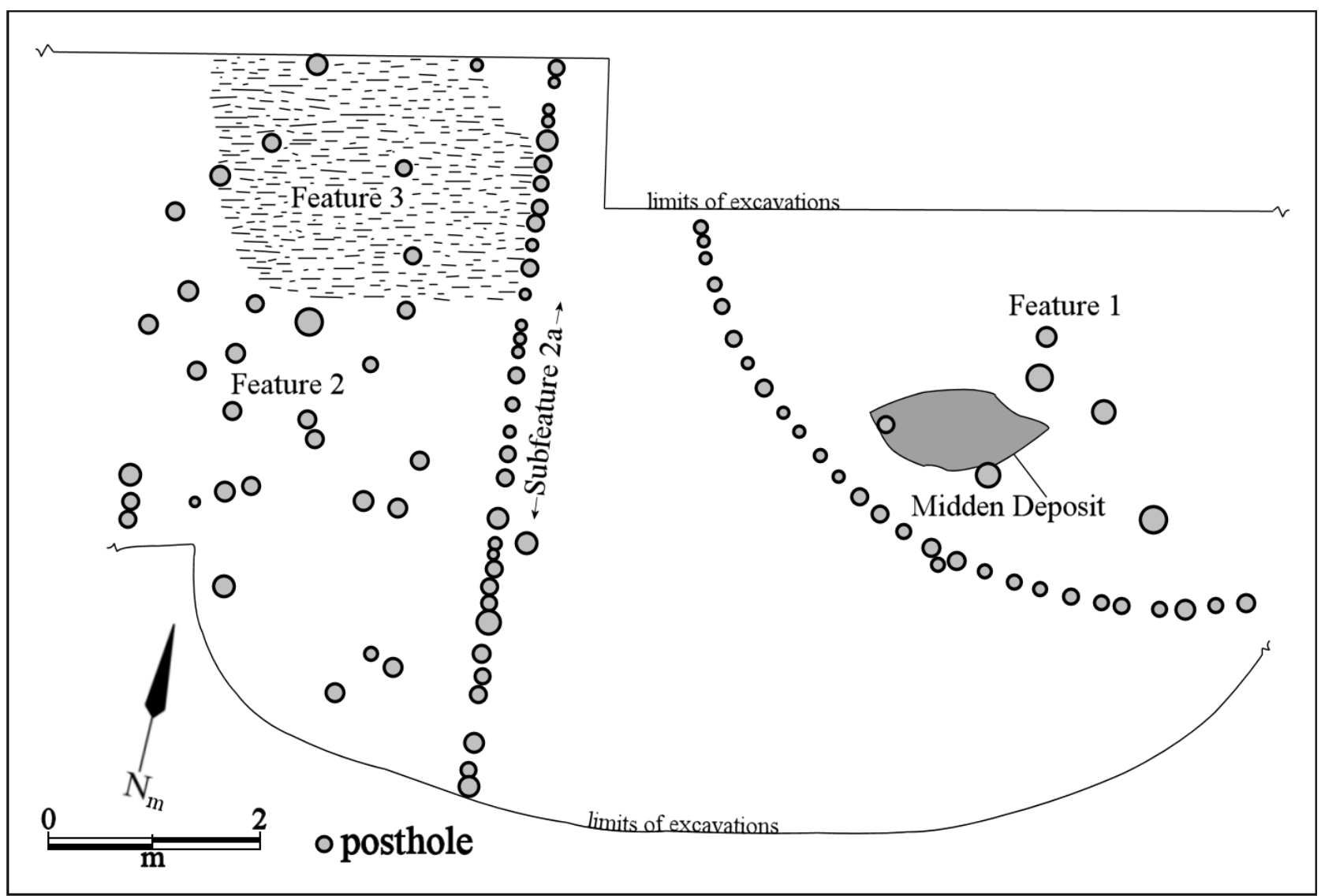

Figure 13. Plan of Features 1-3 in the floor of the trench cut through the Keith mound (Redrawn from Brown 1971a).

In addition to these recognized features, Goldschmidt (1934:30) also noted a concentration of daub about $0.9 \mathrm{~m}$ bs in the central portion of the mound (Brown 1971b labels this Feature 9). This indicates that a structure stood on the mound platform, and then was burned and capped with additional mound fill sediments. Goldschmidt (1934:30-32, 1935:99) also noted a small midden deposit ca. 275 m southwest of the mound, and limited trenching by UT recovered pottery sherds and animal bones in the midden. Finally, several short test trenches were excavated east of the mound on the ridge or terrace remnant (see Figure 11), but no burials or midden deposits were found here, only a few pottery sherds (Goldschmidt 1934:33-34) that Goldschmidt (1935:99) suggested stylistically resembled the pottery found in the midden under the mound and in the mound fill.

In 1971, Kenneth M. Brown, a UT undergraduate student returned to the Keith site along with several UT students and local Texas Archeological Society members to conduct additional investigations (Brown 
1971a). The principal focus was to prepare a topographic contour map of the site area and cut vertical faces along the slumped walls of the 1934 UT trench in the mound, since it was never backfilled. The mound was relatively intact in the spring of 1971 (Figure 14), but one of the landowners leveled the north side of the mound later that year (Figure 15).

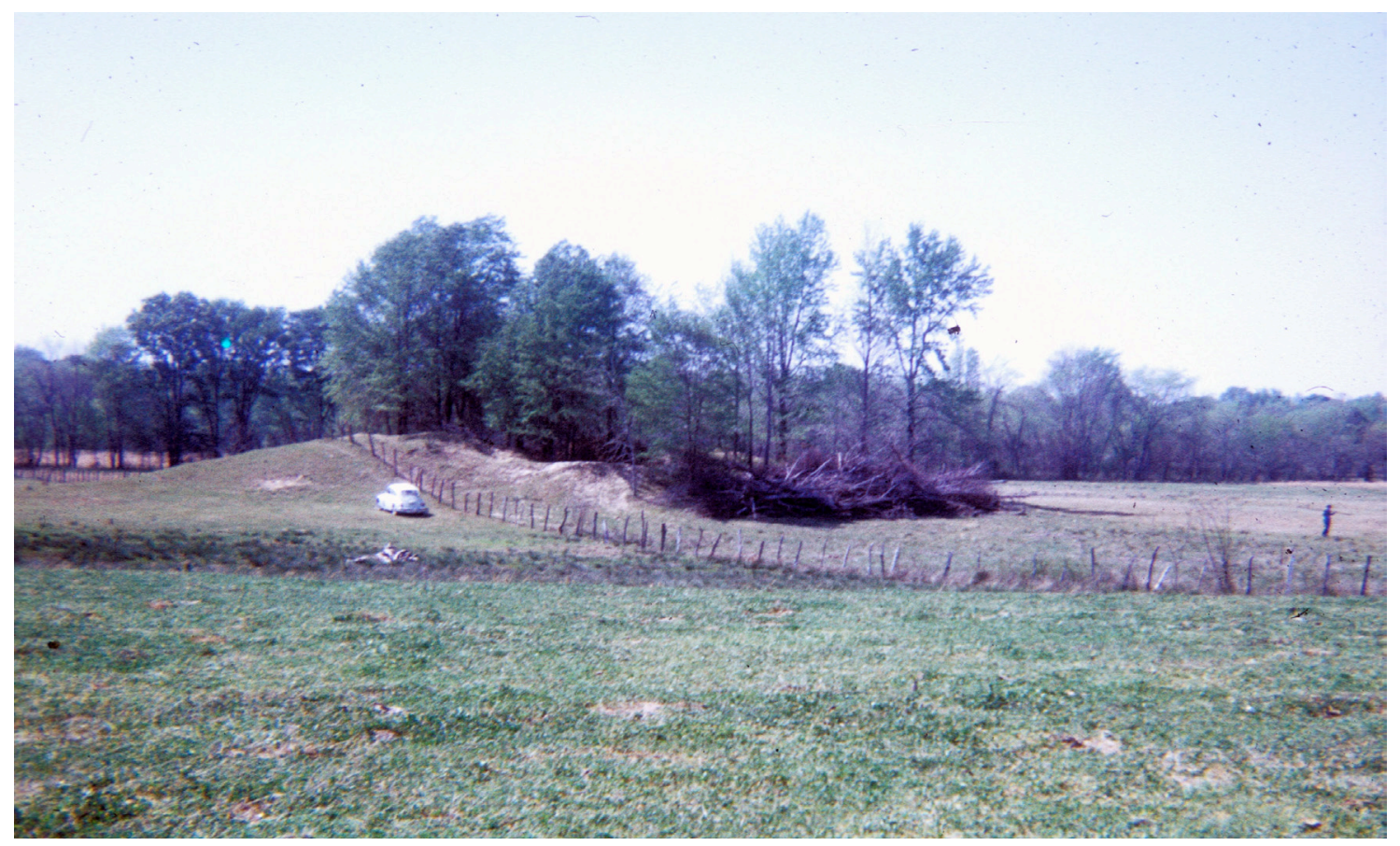

Figure 14. The Keith site mound in April 1971. Photograph by Milton Bell.

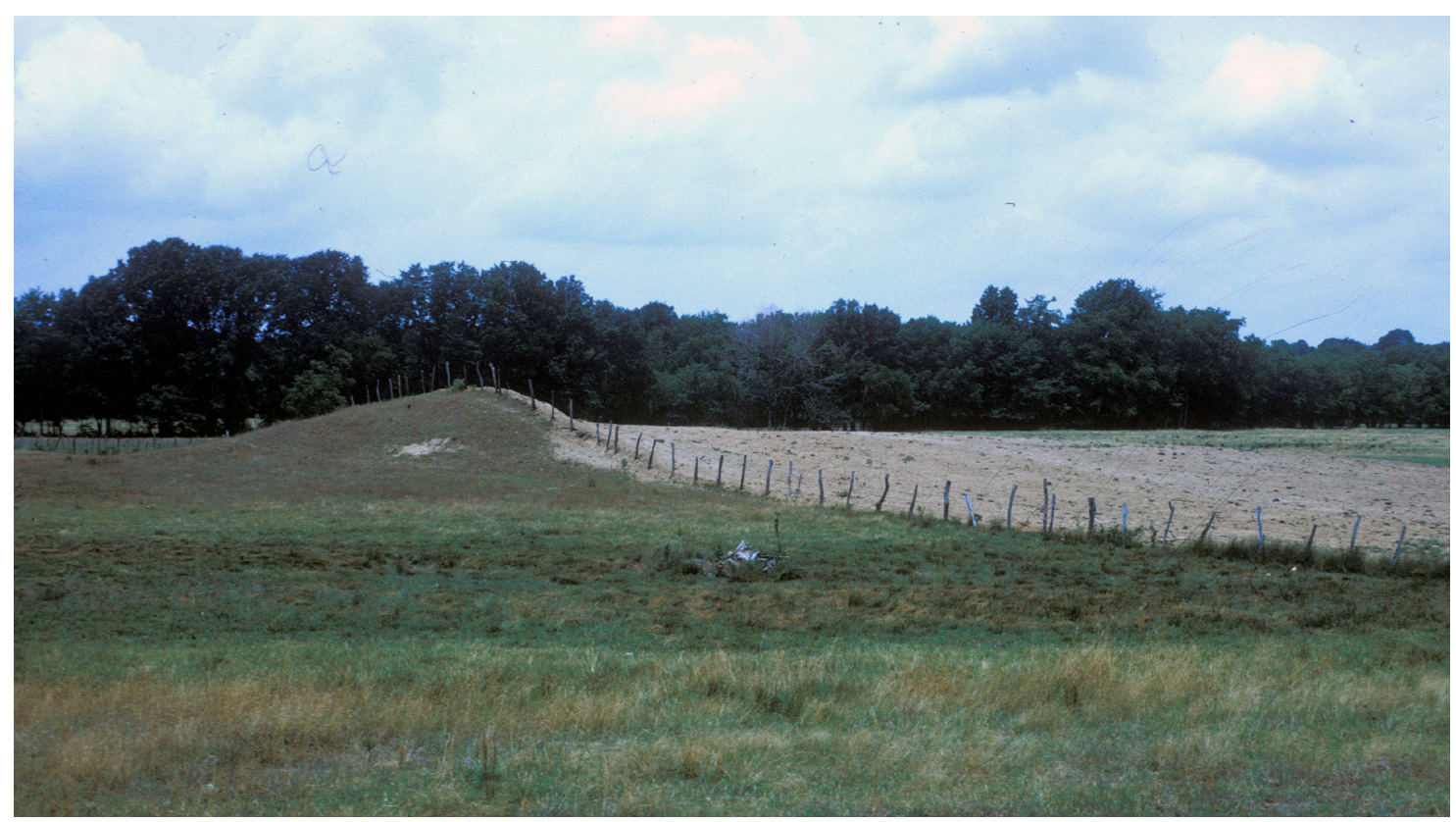

Figure 15. Looking west at the mound at the Keith site after the northern half was leveled and contoured in July 1971. Photograph by Milton Bell. 
Brown (1971a:2-3) suggests that the Keith mound was constructed on a low natural rise in the Hart Creek floodplain. A triangular ridge lies a short distance to the east and southeast of the mound, separated from it by a slough or wetland area that may have formed from its aboriginal use as a borrow pit area (Figure 16).

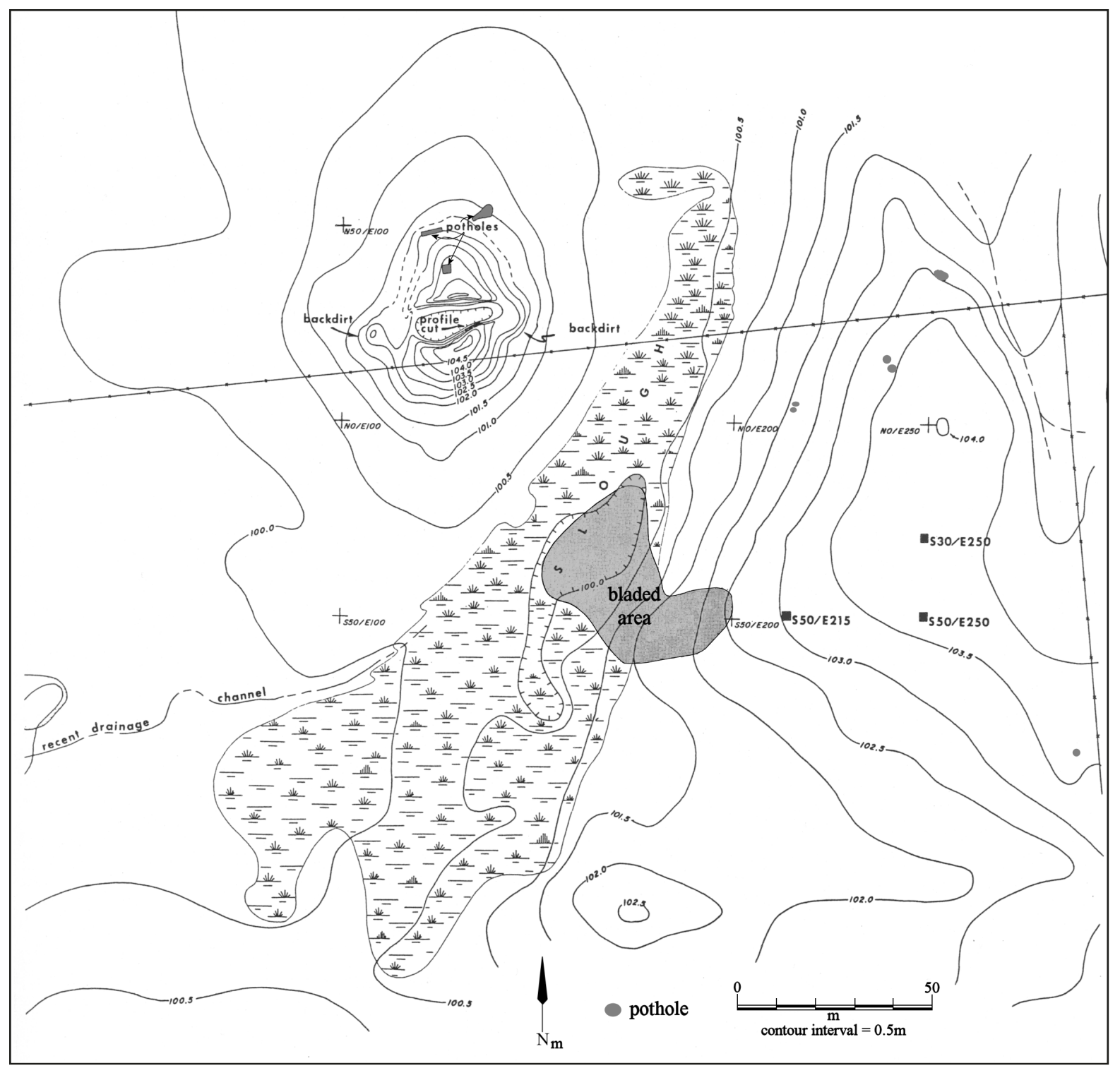

Figure 16. Brown's (1971a) contour map of the Keith site area.

The cleaned mound profile (on the south wall of the 1934 UT trench) was a "complex accumulation of discontinuous loads of varicolored fill. Lenses of what appear to be midden soil, with artifacts and small bits of charcoal, make up a surprisingly large proportion of the fill" (Brown 1971a:7). The fill was primarily comprised of sandy loams and sandy clays, with many ash lenses (Figures 17 and 18). 


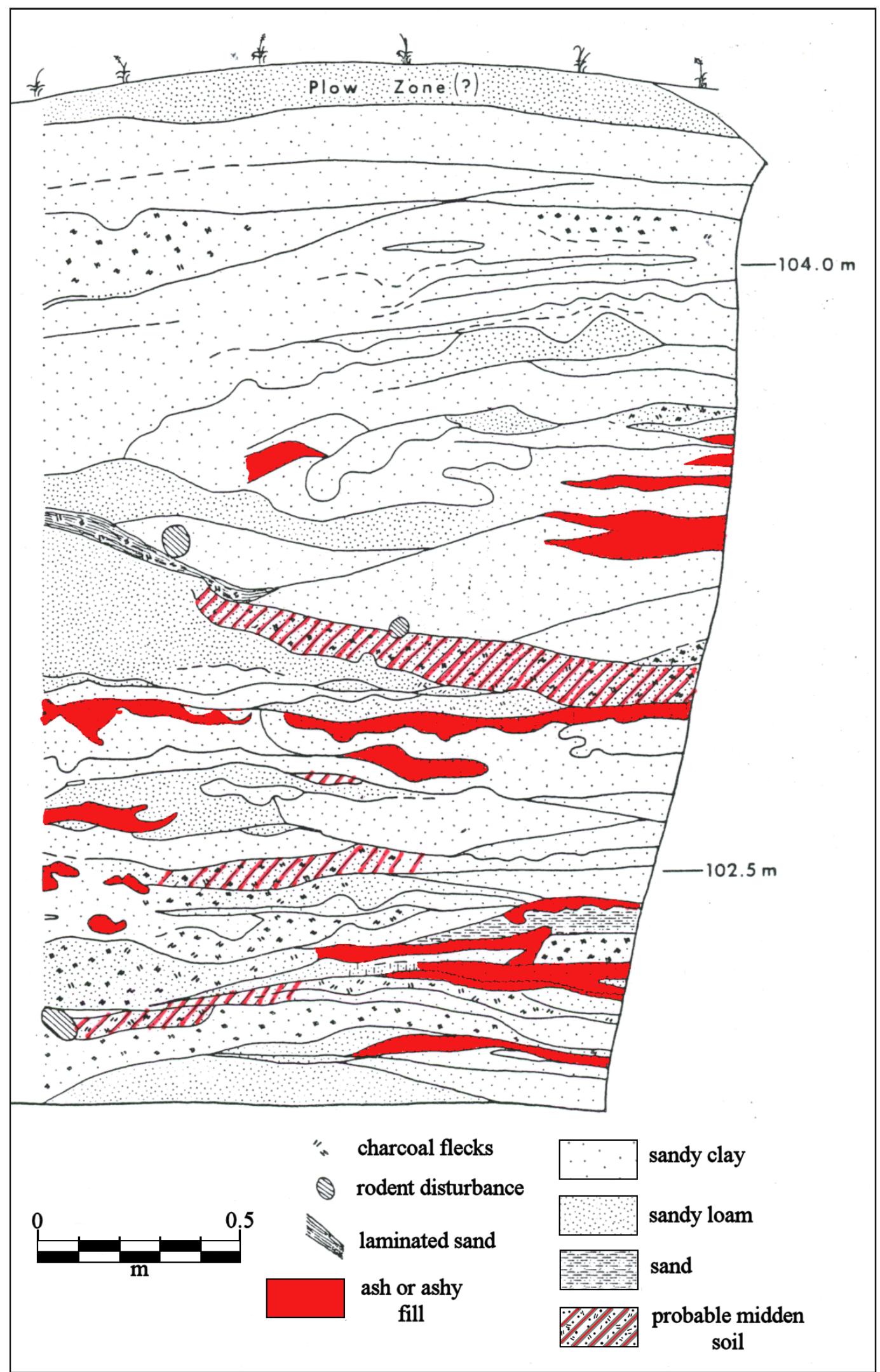

Figure 17.1971 Profile of a section of the 1934 UT trench through the Keith mound. 


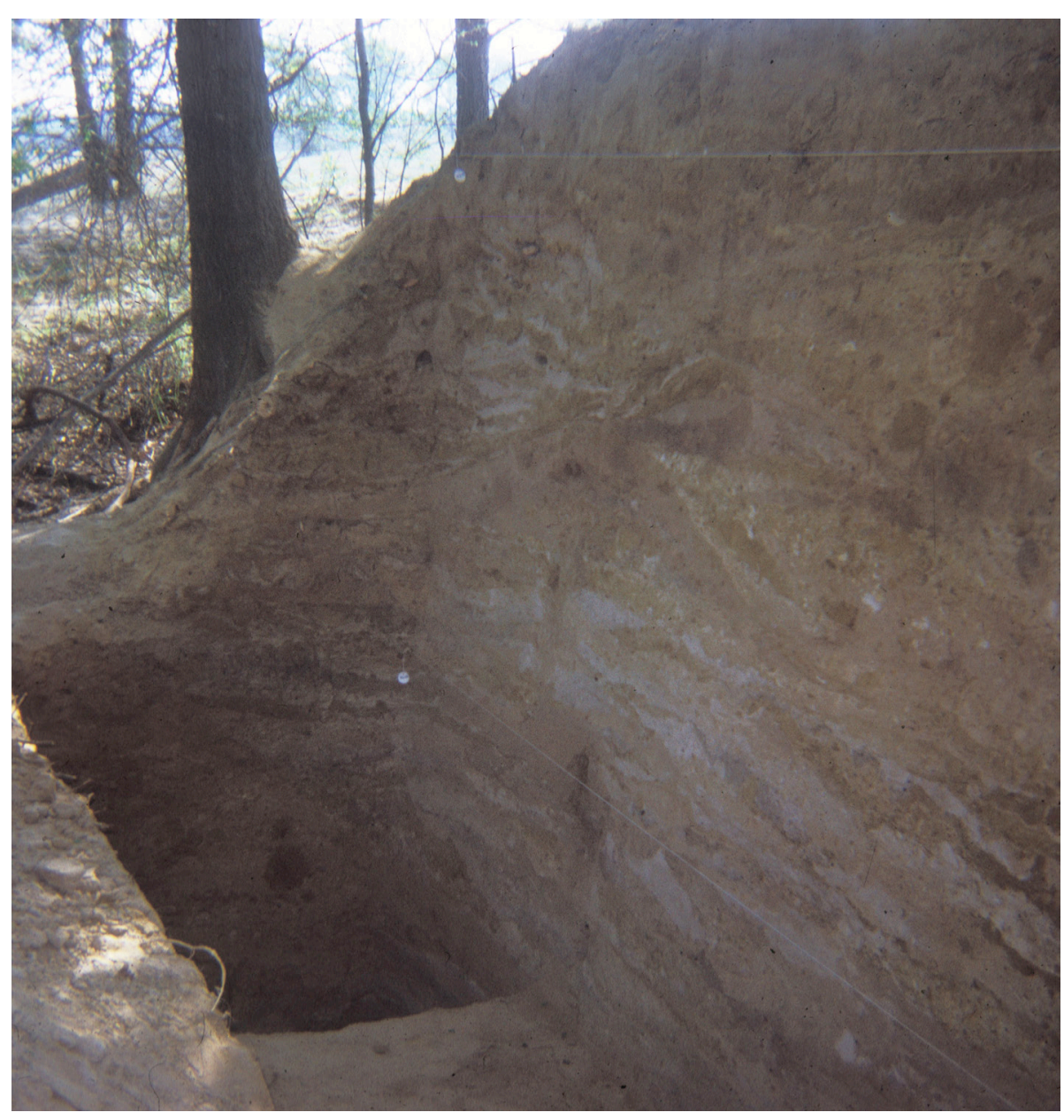

Figure 18. Photograph of the cleaned 1971 profile in the UT trench in the Keith Mound. Photograph by Milton Bell.

Three 2 × 2 m units were excavated in the ridge area southeast of the mound (see Figure 16) to determine if midden deposits were present in this area. However, no midden deposits were identified and the density of artifacts (pottery sherds and lithic flakes) was low, and there were no recovered animal bones. As a further check on the presence or absence of habitation deposits associated with the mound (or the pre-mound midden deposits), Brown (1971b:7) excavated a series of auger tests west of the mound (see Figure 11), but these tests were almost uniformly sterile, except for one small habitation area on a floodplain rise about $200 \mathrm{~m}$ southwest of the mound. Two auger tests here encountered a buried midden zone and considerable charcoal flecking between $25-56 \mathrm{~cm}$ bs and $57-65 \mathrm{~cm}$ bs, respectively. In one of the auger tests, the midden/charcoal zone overlaid a $2 \mathrm{~mm}$ thick lens of orange clay that may have been burned. This clay lens rested atop a dark brown sandy clay. Overall, then, these findings from Brown's work seem to clearly indicate that the Keith mound was not constructed amidst other associated habitation areas, except for the one area of concentrated midden deposits and structures that were eventually covered up by the mound itself.

A single radiocarbon date (Tx-1306) was obtained by Brown as a result of the 1971 work. It came from a sample of charcoal collected from a cleaned mound profile at the west end of the trench excavated by UT in 1934. The charcoal came from depths of 102.6-106.0 $\mathrm{m}$ in elevation, and "appears to derive from pre-existing midden deposits incorporated into mound fill, thus should indicate date at or 
after which middle third of mound was constructed" (Brown n.d.). The 1 sigma 2009 IntCal calibrated age ranges for the composite charcoal sample are A.D. 1309-1356 (0.38) and A.D. 1383-1445 (0.62), and the 2 sigma age range is A.D. 1276-1495 (0.95). If the calibrated age ranges on the charcoal sample are chronologically accurate and the charcoal sample is not the product of a later Titus phase use (for burials or other activities), then this suggests major mound construction at the Keith site anytime after A.D. 1276, but more likely after A.D. 1383 (given the higher probability), during the latter part of the Middle Caddo period in East Texas.

The site also had a late (post-A.D. 1550) Titus phase cemetery with at least 15 burials (with ceramic vessels [Figure 19], Talco arrow points, and celts) that were excavated in the mid- to late 1950s by Ralph Nicholas, Ed German, and several individuals from the Mount Pleasant, Texas, area (Robert L. Turner, Jr. notes; Milton Bell, May 2012 e-mail communication to Waldo Troell; see also Perttula et al. 2010; Thurmond 1990:183-184). These burials were in a cemetery about $100 \mathrm{~m}$ east-southeast of the probable Middle Caddo period earthen platform mound at the site (see Figures 11 and 16), and in an area with both possible Middle Caddo and Titus phase habitation deposits (based on the kinds of decorated sherds found in this area, see below).

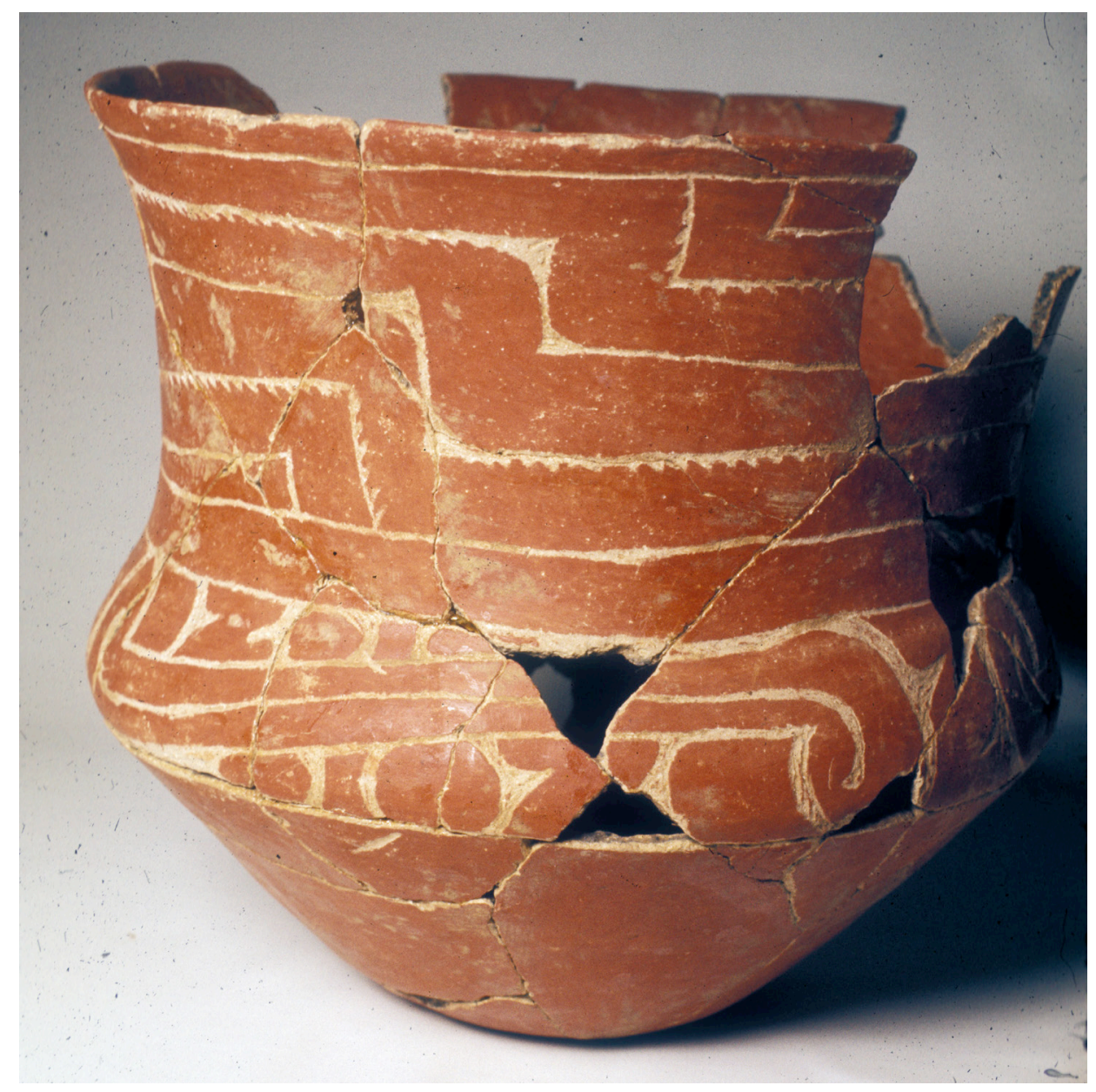

Figure 19. Large engraved compound bowl in a private collection from the Titus phase cemetery area. Photograph taken by Milton Bell in September 1975. 
Notes are available on Burial 1 excavated at the Keith site by Nicholas et al., which was an extended burial oriented east-west ( $1.8 \times 0.56 \mathrm{~m}$ in length and width) and set in a shallow pit cut into the clay Bhorizon. Eight ceramic vessels had been placed in the grave, along with a cache of 76 pieces of lithic debris. There was a ninth vessel from Burial 2. According to Turner's notes, the latter vessel was from a previously dug burial, and "the pot thrown back in probably because it was broken." The nine vessels from the two burials include several varieties - particularly var. McKinney $(\mathrm{n}=3)$ as well as var. unspecified $(n=1)$ - of Ripley Engraved carinated bowls $(n=4)$, a Ripley Engraved, var. unspecified jar, a Wilder Engraved, var. Wilder bottle, an engraved bowl of unidentified type, a plain bottle, and a plain bowl.

In March 1972, Ken Brown documented a portion of the Ed German collection from the burials at the Keith site. In total, the collection included 30 ceramic vessels, seven Talco arrow points, five other arrow points, and a single ground stone celt. Detailed information was obtained on 10 of the vessels (Table 9), and their stylistic character (in combination with the Talco points) strongly suggests they are funerary offerings from late Titus phase (i.e., post-A.D. 1550) burials at the site. The principal fine wares in this collection are several varieties of Ripley Engraved carinated bowls (Figure 20a-c), and the utility wares include La Rue Neck Banded, Cass Appliqued, and cf. Bullard Brushed jars; there was also one plain carinated bowl.

Table 9. Available information on vessels in the Ed German collection from the Keith site.

\begin{tabular}{|c|c|c|c|c|c|}
\hline $\begin{array}{l}\text { Catalog } \\
\text { No. }\end{array}$ & Form & Tp. & $\begin{array}{l}\text { Ht. } \\
(\mathrm{cm})\end{array}$ & $\begin{array}{l}\mathrm{OD} \\
(\mathrm{cm})\end{array}$ & Decoration/Type \\
\hline G-11/3 & DB & $\mathrm{g}$ & 5.0 & 8.0 & $\begin{array}{l}\text { Horizontal engraved panel filled with diagonal } \\
\text { engraved lines }\end{array}$ \\
\hline G-11/6 & Jar & b-g & 13.8 & 13.5 & $\begin{array}{l}\text { cf. Bullard Brushed; horizontal brushed on } \\
\text { the rim and irregular vertical brushed on the body }\end{array}$ \\
\hline G-11/7 & Jar & $\mathrm{b}$ & 22.0 & 17.3 & $\begin{array}{l}\text { La Rue Neck Banded; neck banded rim and } \\
\text { diagonal brushed body }\end{array}$ \\
\hline G-11/9 & Jar & g-b & 18.8 & 15.5 & $\begin{array}{l}\text { Cass Appliqued; punctated rim and vertical } \\
\text { appliqued fillets on the body }\end{array}$ \\
\hline G-11/10 & Jar* & g-b & 24.0 & 20.7 & $\begin{array}{l}\text { La Rue Neck Banded; neck banded rim and } \\
\text { vertical brushed body }\end{array}$ \\
\hline G-11/11 & $\mathrm{CB}$ & $g-b$ & 5.0 & 12.9 & plain \\
\hline G-11/13 & $\mathrm{CB}$ & $\mathrm{g}-\mathrm{b}$ & 15.0 & 15.0 & $\begin{array}{l}\text { Ripley Engraved, var. unspecified; horizontal } \\
\text { scroll motif repeated four times around the rim }\end{array}$ \\
\hline G-11/16 & $\mathrm{CB}$ & $\mathrm{N} / \mathrm{A}$ & 13.7 & 18.0 & $\begin{array}{l}\text { Ripley Engraved, var. McKinney; pendant } \\
\text { triangle motif repeated twice }\end{array}$ \\
\hline G-11/20 & $\mathrm{CB}$ & $\mathrm{b}$ & 13.0 & 23.5 & $\begin{array}{l}\text { Ripley Engraved, var. Galt; scroll and circle } \\
\text { motif repeated four times around the rim }\end{array}$ \\
\hline G-11/24 & Jar & $\mathrm{b}$ & N/A & N/A & La Rue Neck Banded; neck banded rim \\
\hline
\end{tabular}

*rim peaks; $\mathrm{DB}=$ deep bowl; $\mathrm{CB}=$ carinated bowl; Tp.=temper; $\mathrm{g}=\mathrm{grog} ; \mathrm{b}=\mathrm{bone} ; \mathrm{Ht} .=$ height; $\mathrm{OD}=$ orifice diameter

Milton Bell (May 2012 e-mail communication to Waldo Troell) indicates that a Billy L. Anderson, a known collector of Caddo artifacts, also excavated several burials in the 1980s at the site, south of and near the mound. This was in the area of the Volkswagen on Figure 14. 


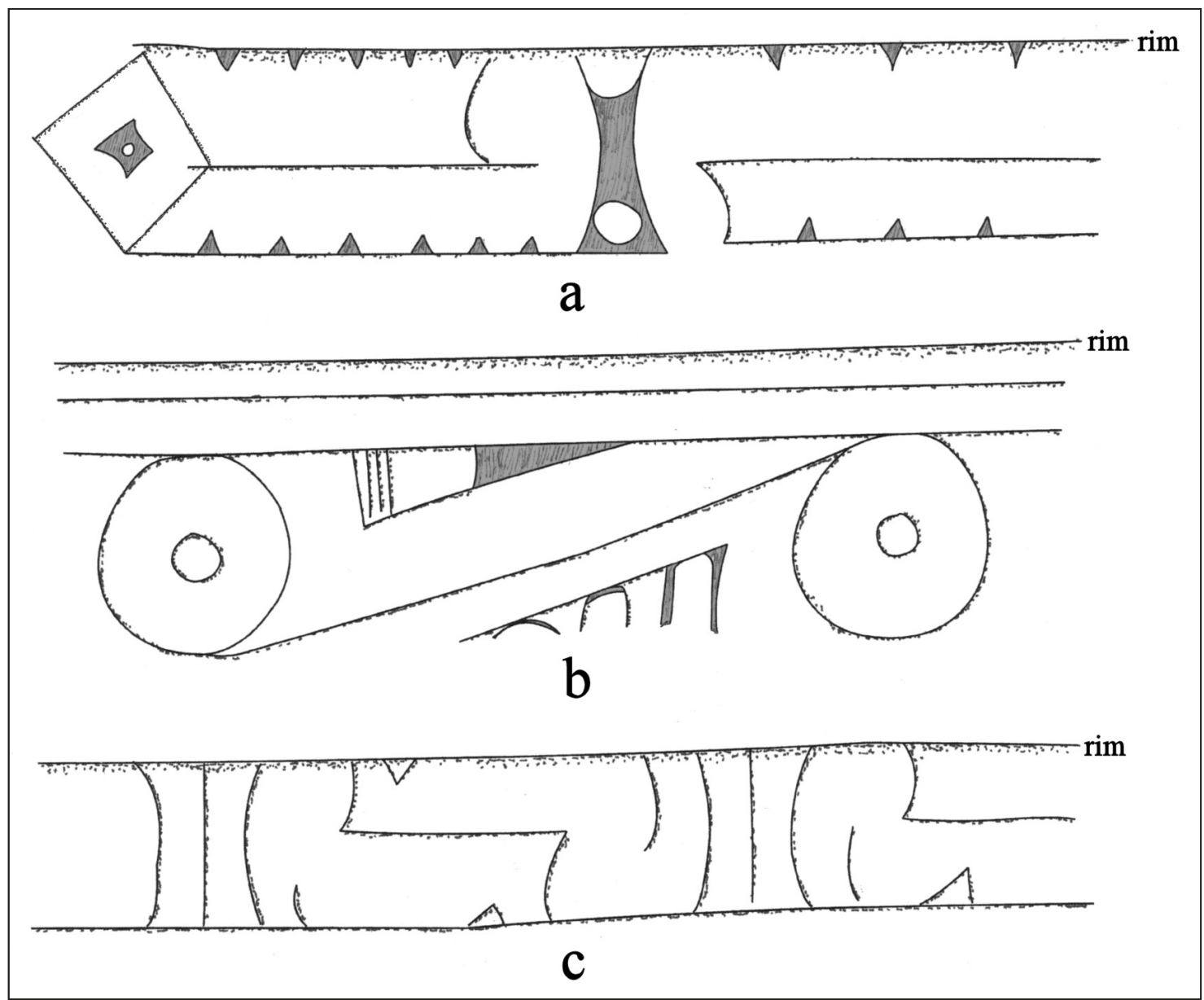

Figure 20. Engraved motifs on Ripley Engraved carinated bowls in the Ed German collection from the Keith site: a, Ripley Engraved, var. McKinney (G-11/16); b, Ripley Engraved, var. Galt (G-11/20); c, Ripley Engraved, var. unspecified (G-11/13).

\section{Material Culture Remains}

\section{Ceramic Sherds}

As with the Hale site, the focus of the ceramic analysis of the sherds from the Keith site is on the decorated sherds $(n=509)$. In particular, our concern was with the decorative methods and decorative elements present in both the utility wares and fine wares in the assemblage. Also of interest is the use of different tempers in vessel manufacture, especially the use of burned bone as a temper.

\section{Use of Temper in Ceramic Vessel Manufacture}

The majority of the utility ware and fine ware vessel sherds at the Keith site are from grog-tempered vessels (ca. 73 percent). Nevertheless, a significant portion of these decorated wares were tempered with crushed and burned bones by ancestral Caddo potters, between 26.4-29.7 percent by ware (Table 10). There is no significant difference between the wares in the proportion that was either grog or bone-tempered. 
Table 10. Use of bone temper in utility ware and fine ware sherds from the Keith site.

\begin{tabular}{lccc}
\hline Ware & $\begin{array}{c}\text { No. of sherds with } \\
\text { bone temper }\end{array}$ & No. of sherds & $\begin{array}{c}\text { Percent bone- } \\
\text { tempered }\end{array}$ \\
\hline Utility & 96 & 364 & 26.4 \\
Fine & 43 & 145 & 29.7 \\
\hline Totals & 139 & 509 & 27.3 \\
\hline
\end{tabular}

The proportion of bone-tempered vessel sherds at both the Hale and Keith sites are quite comparable by wares, ranging from 22.4-26.4 percent among the utility wares at the two sites, and 29.7-29.8 percent among the fine ware sherds (see Tables 2 and 10). Fine wares at both sites tend to have slightly higher proportions of bone temper use than do the utility wares, but the proportions are not significantly different.

\section{Decorated Sherds}

The decorated sherds $(n=509)$ from the Keith site in the TARL collections include 117 rim sherds and 392 body sherds (Table 11). ${ }^{1}$ About 71.5 percent of the sherds are from utility wares - wet paste decorations, primarily on jars - and the remainder are from fine wares decorated with engraved, red-slipped, and red-slipped-punctated elements. The proportion of rims among the two wares are roughly the same: 69 percent are from utility wares and 31 percent are from fine wares.

Table 11. Decorated sherds from the Keith site.

\begin{tabular}{lccc}
\hline Decorative Method & Rim & Body & N \\
\hline Utility Ware & 2 & & 3 \\
Appliqued & - & 3 & 3 \\
Appliqued-Incised & - & 1 & 1 \\
Appliqued-Punctated & - & 55 & 55 \\
Brushed & - & 9 & 9 \\
Brushed-Incised & - & 1 & 1 \\
Brushed-Incised-Appliqued & 2 & - & 2 \\
Brushed-Punctated & 47 & 108 & 155 \\
& 12 & 32 & 44 \\
Incised & - & 1 & 1 \\
Incised-Punctated & & & 1 \\
Incised-Punctated-Brushed & 1 & & 2 \\
Neck Banded & - & 2 & 1 \\
Pinched & - & 1 & 3 \\
Punctated, cane & 2 & &
\end{tabular}


Table 11. Decorated sherds from the Keith site, cont.

\begin{tabular}{lrrr}
\hline Decorative Method & Rim & Body & N \\
\hline Punctated, Fingernail & 2 & 24 & 26 \\
Punctated, Tool & 13 & 44 & 57 \\
Sub-total & 81 & 283 & 364 \\
& & & \\
Fine Ware & 28 & 60 & 88 \\
Engraved & 7 & 48 & 55 \\
Red Slipped & 1 & 1 & 2 \\
Red Slipped-Punctated & 36 & 109 & 145 \\
Sub-total & 117 & 392 & 509 \\
\hline Totals & & & \\
\hline
\end{tabular}

\section{Appliqued}

The first of the appliqued rim sherds has a series of appliqued nodes at the lip, while the other has a horizontal appliqued ridge below the lip; both of these sherds were recovered from the surface of the site. A body sherd from the midden east of the mound has parallel appliqued ridges (probably oriented vertically on the vessel body) as the decorative element.

\section{Appliqued-Incised}

One body/base sherd has vertical appliqued ridges on the vessel body, with diagonal incised lines; these are probably filling panels created by four appliqued ridges spaced around the vessel. A second body sherd (from the surface) has a single straight appliqued fillet with parallel incised lines on either side of the fillet (see Figure 26h, below). The third appliqued-incised body sherd (from an unknown provenience) has a straight appliqued fillet and diagonal opposed incised lines on either side of the fillet. These three sherds may be from Pease Brushed-Incised jars (see Suhm and Jelks 1962).

\section{Appliqued-Punctated}

This body sherd is from the surface of the Keith site. It has a single straight appliqued ridge and adjacent parallel rows of tool punctations.

\section{Brushed}

The 55 brushed sherds are from the body of utility ware jars. About 89 percent of these sherds have parallel brushing marks; 5 percent have opposed brushing marks; 4 percent have overlapping brushing marks; and 2 percent have horizontal brushing marks. The brushed body sherds in the 1934 excavations are from the following contexts: surface $(n=35)$; midden east of Mound No. $1(n=11)$; west Trench, mixed levels $(n=3)$; east Trench, sub-mound midden zone $(n=1)$. 


\section{Brushed-Incised}

The brushed-incised body sherds have parallel brushing marks and incised lines; these sherds are probably from the body of utility ware jars. They were found either on the surface, in the midden east of Mound No. 1, or in mixed levels in the west Trench.

\section{Brushed-Incised-Appliqued}

This body sherd, from an unknown provenience, has parallel brushed-incised marks and lines adjacent to a straight appliqued fillet. It is probably from a Pease Brushed-Incised jar.

\section{Brushed-Punctated}

Both brushed-punctated rim sherds have horizontal brushing on the rim, as well as a single tool punctated row under the vessel lip and pushed through the brushing. They were found in an unknown provenience as well as in the midden east of the mound.

\section{Incised}

Sherds with incised decorative elements are the most common in the Keith site ceramic assemblage, accounting for 42 percent of all the utility ware sherds (see Table 10). The design elements principally feature diagonal, diagonal opposed, horizontal, and cross-hatched incised lines on the rim and/or body of jars and bowls (Table 12); 60 percent of the rims have diagonal or diagonal opposed incised decorative elements. These sherds are likely from Canton Incised, Davis Incised, and Dunkin Incised vessels (Figure 21a-f, h-i), and there is one rim sherd from an East Incised bowl with lip tabs (Figure 21g). The East Incised rim sherd was recovered in the sub-mound midden zone in the east Trench.

Table 12. Decorative elements on incised rim and body sherds from the Keith site.

\begin{tabular}{lccc}
\hline Decorative element & Rim & Body & N \\
\hline cross-hatched lines & 7 & 7 & 14 \\
curvilinear line & - & 1 & 1 \\
diagonal lines & 17 & 5 & 22 \\
diagonal-horizontal lines & - & 4 & 4 \\
diagonal opposed lines & 11 & 24 & 35 \\
diagonal-vertical lines & - & 1 & 1 \\
& 10 & 2 & 12 \\
horizontal lines & 1 & 2 & 3 \\
horizontal-cross-hatched lines & 1 & - & 1 \\
horizontal-curvilinear lines & - & 1 & 1 \\
opposed lines & - & 54 & 7 \\
parallel lines & - & 7 & 155 \\
straight line & 47 & 108 & 54 \\
\hline Totals & & & \\
\hline
\end{tabular}




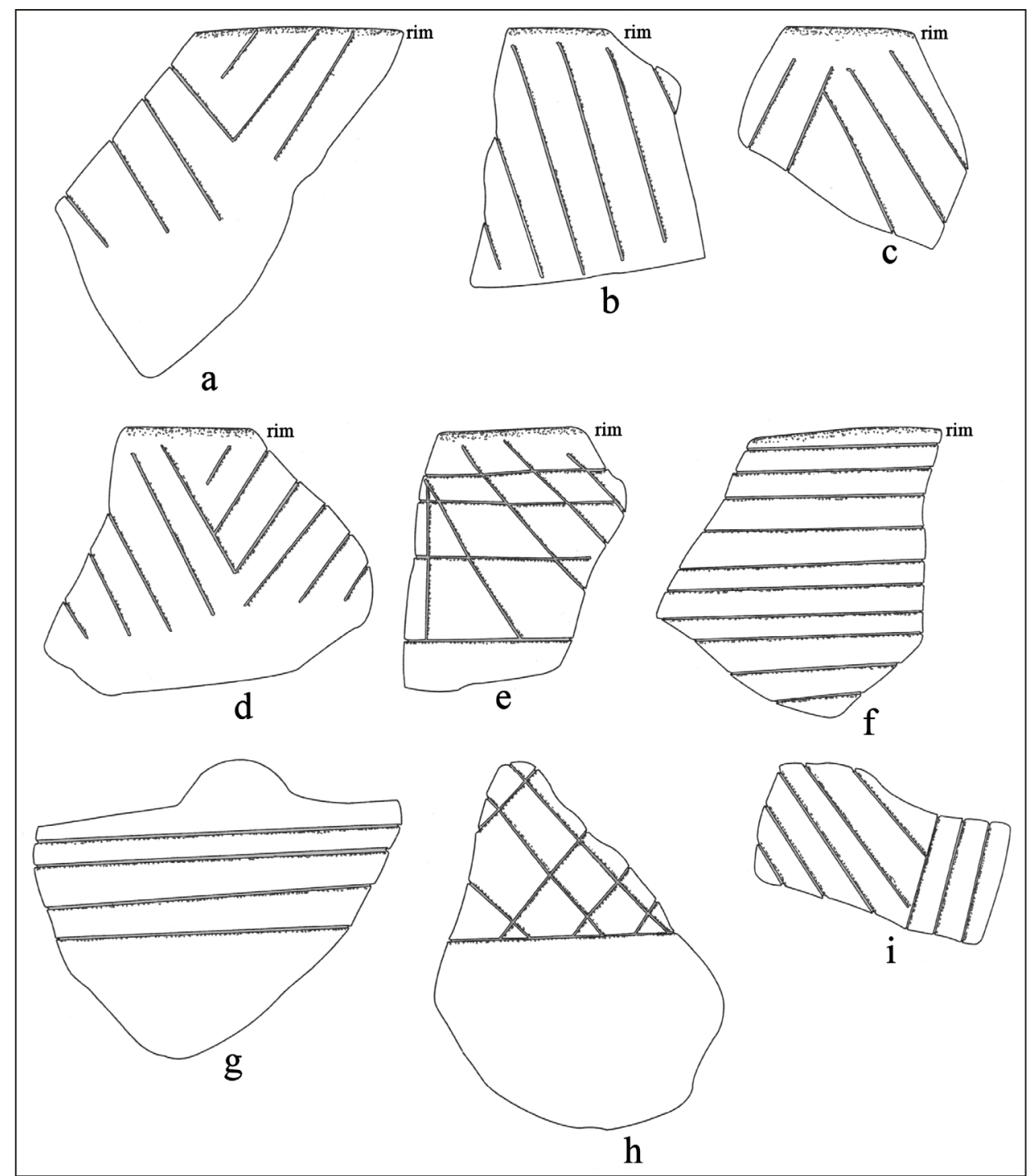

Figure 21. Incised rim and body sherd decorative elements: a-g, rim sherds; h-i, body sherds.

The incised rim and body sherds are from each excavated context at the Keith site. This includes the surface ( $n=22$, see Figure 21c); east Trench, sub-mound midden zone ( $\mathrm{n}=17$, see Figure 21g-h); west Trench, mixed levels $(n=2)$; west Trench, sub-mound midden zone ( $n=7$, see Figure 21a); upper levels in the mound ( $n=15$, see Figure 21b); central Trench section, sub-mound midden zone $(n=2)$; midden east of the mound ( $n=27$, see Figure 21e); and in the east Trench east of the mound $(n=6)$. Sherds from incised utility ware vessels are particularly abundant in the midden east of the mound, in sub-mound midden deposits, as well as in the upper levels of the mound.

\section{Incised-Punctated}

The incised-punctated sherds in the Keith site ceramic assemblage comprise between 11-13 percent of the utility ware rim and body sherds recovered at the site (see Table 11). Utility ware jars have a diverse range of incised-punctated decorative elements, although almost 95 percent of these sherds have tool punctations (Table 13 and Figures 22a-f and 23a-c). Only 4.5 percent of the incised-punctated sherds 
feature circular or semi-circular incised elements filled with punctations (Figure 23a-b), as the remainder have simple geometric elements, including diagonal (Figure 22d), diagonal opposed (Figure 22a, f), horizontal (Figure 22c, e), opposed, triangular, and vertical incised lines (Figure 22b). These incised elements either created zones filled with punctates, or they are framed by rows of punctations that were placed under the vessel lip and/or at the rim-body juncture (Figure 22a-c). On one rim-body sherd with vertical and diagonal incised lines on the rim, and tool punctated rows under the lip and at the rim-body juncture, the vessel body has diagonal incised lines (Figure 22b).

Table 13. Decorative elements on incised-punctated rim and body sherds from the Keith site.

\begin{tabular}{|c|c|c|c|}
\hline Decorative element & Rim & Body & $\mathrm{N}$ \\
\hline band punctated (i.e., incised band filled with tool punctates) & - & 1 & 1 \\
\hline band punctated and horizontal incised line & 1 & - & 1 \\
\hline $\begin{array}{l}\text { circular and semi-circular incised zones filled with } \\
\text { tool punctates }\end{array}$ & - & 2 & 2 \\
\hline $\begin{array}{l}\text { diagonal incised and triangular zone filled with tool } \\
\text { punctates }\end{array}$ & 1 & - & 1 \\
\hline $\begin{array}{l}\text { diagonal opposed lines and triangular zone filled with } \\
\text { tool punctates }\end{array}$ & 7 & 1 & 8 \\
\hline $\begin{array}{l}\text { diagonal opposed lines, and tool punctated zone under } \\
\text { lip and at rim-body juncture }\end{array}$ & 1 & 1 & 2 \\
\hline $\begin{array}{l}\text { diagonal and horizontal lines and tool punctated } \\
\text { row at rim-body juncture }\end{array}$ & - & 1 & 1 \\
\hline horizontal incised lines and tool punctated row under lip & 1 & - & 1 \\
\hline $\begin{array}{l}\text { horizontal incised lines and diagonal tool } \\
\text { punctated rows }\end{array}$ & - & 1 & 1 \\
\hline opposed incised lines and adjacent tool punctated zone & - & 1 & 1 \\
\hline parallel incised lines and adjacent tool punctated zone & - & 3 & 3 \\
\hline straight incised line and adjacent cane punctated zone & - & 1 & 1 \\
\hline straight incised line and adjacent fingernail punctated zone & - & 1 & 1 \\
\hline straight incised line and adjacent tool punctated zone & - & 2 & 2 \\
\hline straight line with overlying tool punctated rows & - & 1 & 1 \\
\hline triangular incised zone filled with tool punctates & - & 15 & 15 \\
\hline $\begin{array}{l}\text { vertical lines on body; tool punctated row at rim- } \\
\text { body juncture }\end{array}$ & - & 1 & 1 \\
\hline $\begin{array}{l}\text { vertical and diagonal opposed lines and tool punctated } \\
\text { rows under lip and at rim-body juncture; diagonal } \\
\text { incised on body }\end{array}$ & 1 & - & 1 \\
\hline Totals & 12 & 32 & 44 \\
\hline
\end{tabular}




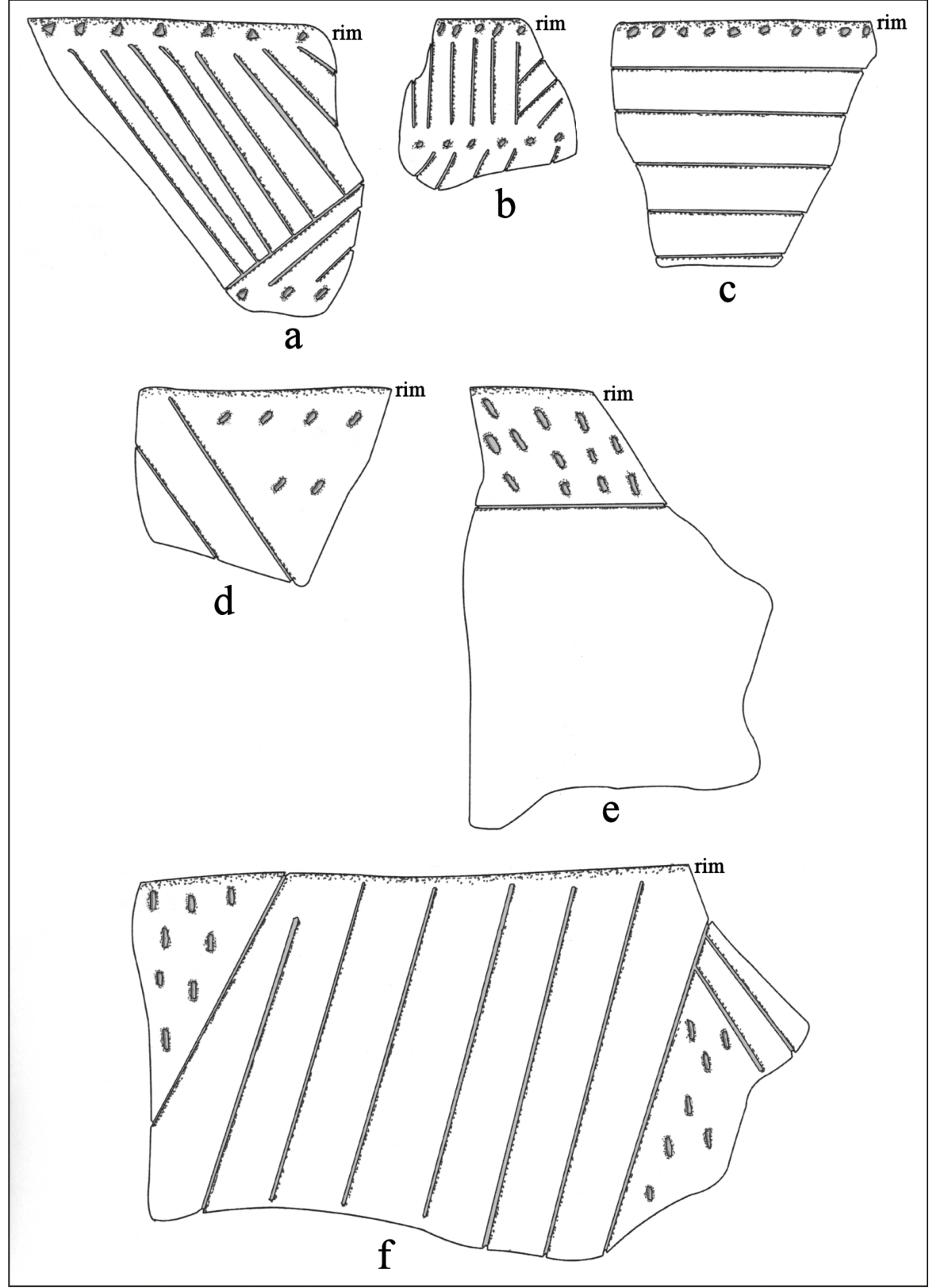

Figure 22. Incised-punctated rim sherd decorative elements.

Typologically, the sherds with triangular incised zones filled with punctates are probably from Canton Incised vessels (see Suhm and Jelks 1962:Plate 12d-e, h-i). The sherds with circular and semi-circular incised zones filled with punctations (see Figure 23a-b) may be from late Crockett Curvilinear Incised vessels - probably bowls - but more of the incised-punctated motif is needed to feel confident in this typological identification.

The incised-punctated rim and body sherds from the Keith site have been recovered in several distinct contexts. These include: surface $(n=4)$; west Trench, mixed levels $(n=2)$; west Trench, sub-mound midden zone ( $n=2$, see Figure 23c); upper levels in mound excavations $(n=3)$; east Trench, sub-mound midden zone $(n=5)$; midden east of the mound $(n=8$, see Figure 22a, $d)$; sub-mound midden zone $(n=1)$; and central Trench, sub-mound midden zone ( $\mathrm{n}=1$, see Figure $22 \mathrm{f})$. 


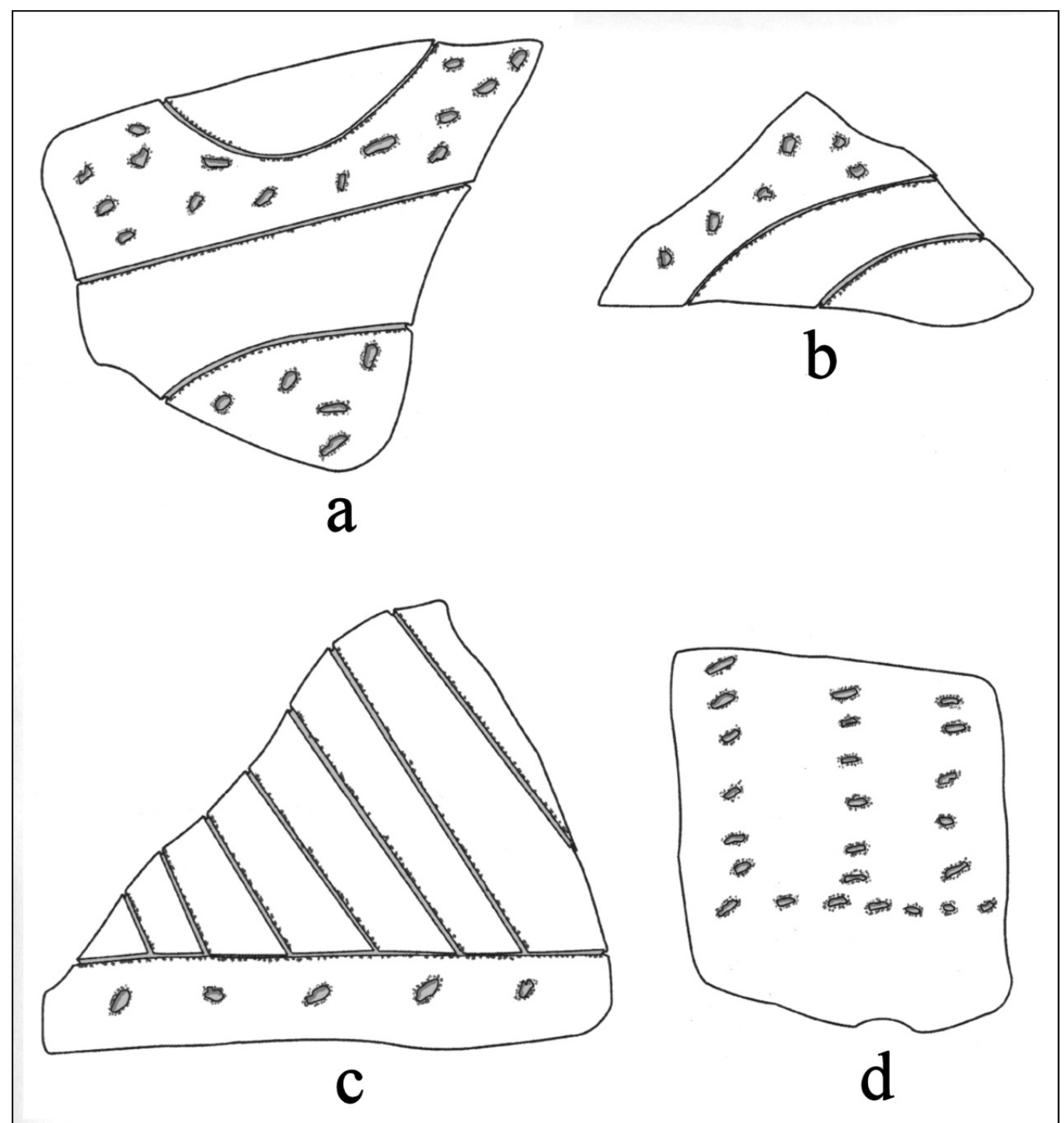

Figure 23. Incised-punctated and punctated body and lower rim sherd decorative elements: a-c, incised-punctated; d, Weches Fingernail Impressed, var. Alto.

\section{Incised-Punctated-Brushed}

This lower rim-body sherd from a Pease Brushed-Incised jar is from the surface of the site. The rim has a series of closely-spaced horizontal incised lines as well as a single row of tool punctations at the rim-body juncture (see Figure 26g, below). The vessel body has diagonal brushed marks as well as at least one diagonal row of linear tool punctations pushed through the brushing. 


\section{Neck Banded}

The one neck banded sherd is a rim (everted rim and a rounded lip) from a bone-tempered La Rue Neck Banded jar. It was found on the surface. This sherd, along with a few sherds from other utility wares and several engraved sherds, is evidence of the Late Caddo (post-ca. A.D. 1430) use of the Keith site.

\section{Pinched}

Both pinched body sherds have parallel rows of pinching as a decorative element; they were found on the surface. These are likely from Killough Pinched jars.

\section{Punctated, cane}

The single cane punctated body sherd has rows of cane punctates. It was recovered in the upper levels of the trench excavated in the mound at the Keith site.

\section{Punctated, circular}

There are two rims (direct rims with rounded lips) decorated with rows of circular punctations, as well as one circular punctated body sherd. The rims were found on the surface of the site, while the body sherd came from a test trench east of the mound.

\section{Punctated, Fingernail}

About 30 percent of the punctated sherds from the Keith site have fingernail punctated elements. They occur in horizontal rows on both the rim and the body of utility ware jars (Table 14).

Table 14. Decorative elements on fingernail and tool punctated rim and body sherds from the Keith site.

\begin{tabular}{lcrr}
\hline Decorative element & Rim & Body & N \\
\hline fingernail punctated rows & 2 & 22 & 24 \\
fingernail punctated rows at rim-body juncture & - & 2 & 2 \\
tool punctated row under lip & 4 & - & 4 \\
tool punctated rows & 9 & 43 & 52 \\
tool punctated rows, horizontal and vertical & - & 1 & 83 \\
\hline Totals & 15 & 68 & 1 \\
\hline
\end{tabular}

\section{Punctated, Tool}

Tool punctated sherds in the Keith site ceramic assemblage comprise ca. 65 percent of the sherds with punctated decorative elements (see Table 11), and 76 percent of the punctated rims. These sherds come from jars or carinated bowls ( $\mathrm{n}=2$ sherds, one from the midden east of the mound) that have horizontal rows of tool punctations on the rim-beginning commonly under the vessel lip - and vessel 
body. One body sherd is from a Weches Fingernail Impressed, var. Alto jar (see Figure 23d; Stokes and Woodring 1981:Figure 22m).

The fingernail and tool punctated sherds are from a variety of contexts at the site (where the provenience is known), including: midden east of the mound $(n=15)$; east Trench, sub-mound midden zone $(\mathrm{n}=7)$; central Trench, sub-mound midden zone $(\mathrm{n}=3)$; west Trench, sub-mound midden zone ( $\mathrm{n}=2)$; upper level of trench through the mound $(n=8)$; west Trench, mixed levels $(n=1)$; and surface $(n=12)$.

\section{Engraved}

Sherds from engraved vessels comprise 61 percent of the fine wares from the Keith site (see Table 10). The other fine wares have red-slipped (38 percent of the fine wares) and red-slipped-punctated (1.4 percent) decorative elements.

Of the engraved sherds (including two with a red slip) that are from the primary component at the site (i.e., the Middle Caddo period component), 75 percent are from carinated bowls, compound bowls, and bowls (Table 15). The remainder are from bottles or are rim and lower rim sherds from a post-A.D. 1430 Caddo occupation at the site (see below).

Table 15. Decorative elements on engraved bowl and carinated rim and body sherds from the Keith site.

\begin{tabular}{lccc}
\hline Decorative element & Rim & Body & N \\
\hline cross-hatched zone & 1 & 2 & 3 \\
cross-hatched lines & 1 & 1 & 1 \\
curvilinear hatched zone & - & 1 & 9 \\
curvilinear hatched zone and straight line & - & 1 & 1 \\
curvilinear lines & - & $5^{*}$ & 1 \\
diagonal lines & 10 & - & 8 \\
diagonal-horizontal lines & 1 & 4 & 6 \\
diagonal opposed lines & 4 & - & 1 \\
horizontal lines & 6 & - & 11 \\
horizontal engraved-diagonal opposed hatched zones & 1 & 11 & 6 \\
parallel lines & & $6 * *$ & 1 \\
straight line & - & 1 & 1 \\
vertical hatched zone & - & 42 & 66 \\
vertical-rectangular elements & - & - & 1 \\
\hline Totals & 24 & & \\
\hline
\end{tabular}

*one sherd has an interior/exterior red slip; **one sherd has an exterior red slip 
The engraved rim sherds in the Keith site fine ware assemblage are dominated by diagonal and horizontal elements (see Table 14), as well as rims with diagonal opposed engraved lines. These rather simple decorations on the rim sherds suggest that many are from Sanders Engraved vessels (see Suhm and Jelks 1962:137 and Plate 69) or from Hickory Engraved vessels with horizontal lines encircling the rim. One of the distinctive aspects of the fine wares from the Keith site is the number of sherds $(n=16,23$ percent of the fine wares, see Table 14) with hatched or cross-hatched zones (see Figure 24a-f), including curvilinear, triangular, and diagonal (or ladder)-shaped zones. The use of hatched or cross-hatched engraved lines to fill zones is a common characteristic of East Texas ceramic assemblages from Middle Caddo period times through the Late and Historic Caddo periods.

One diagonal engraved rim has an exterior thickened projection from its lip (see Figure 24g) that is similar to the lip treatment on some East Incised (or engraved) vessels (see Suhm and Jelks 1962:Plate

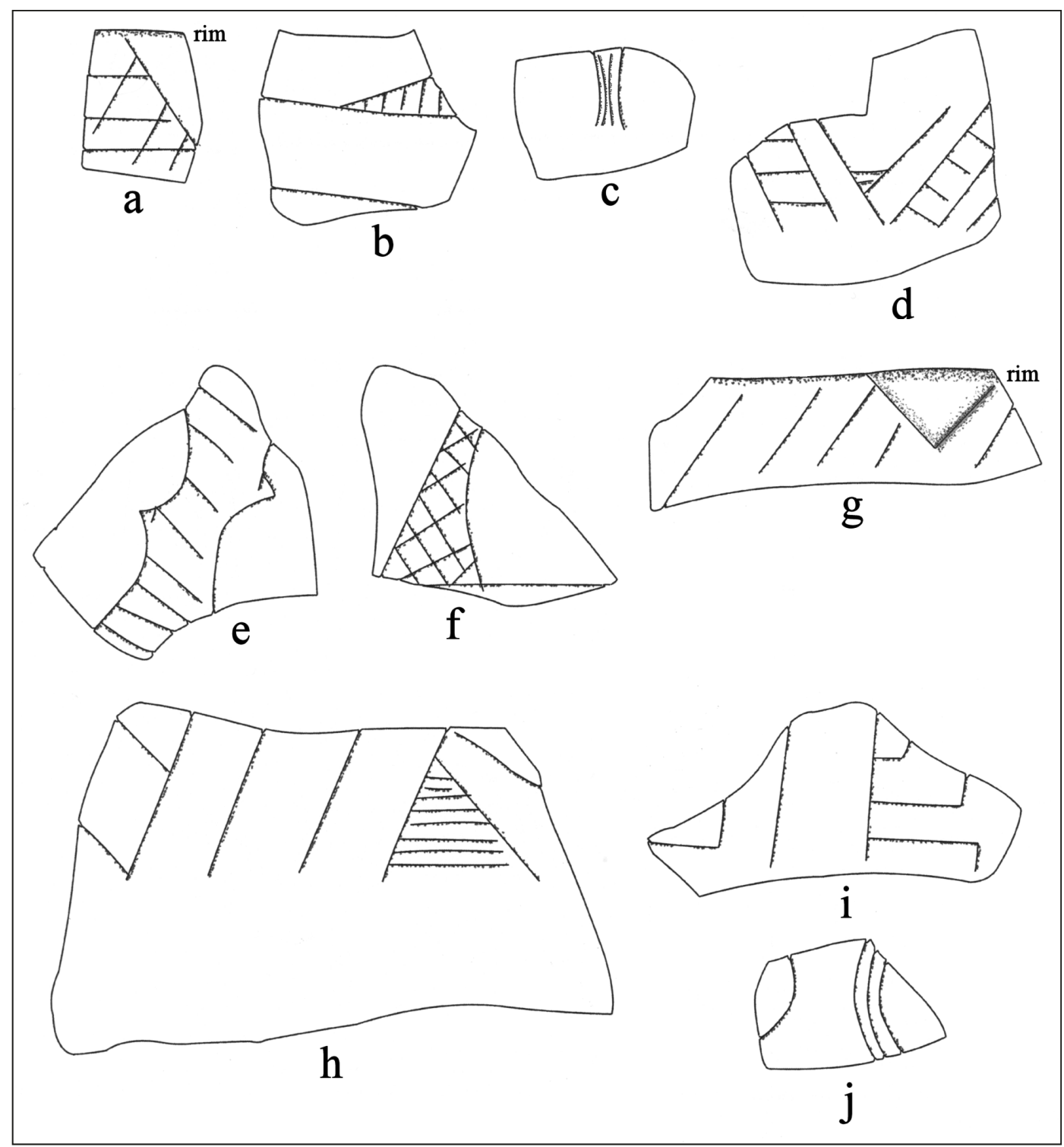

Figure 24. Engraved rim and body sherd decorative elements. 
21j). A lower rim sherd from a carinated bowl has decorative elements reminiscent of Holly Fine Engraved, with diagonal opposed engraved lines and a triangle element filled with hatched lines (see Figure $24 \mathrm{~h}$ ), except the engraved elements are not fine line in execution and the triangle element has not been excised. Two of the engraved sherds ( 3 percent) from bowls and carinated bowls have a red slip on one or both surfaces. Another seven sherds (10.6 percent) have a red clay pigment rubbed in the engraved lines, including two sherds from the sub-mound midden zone (see Figure 24c, f) and a rim from the midden east of the mound (see Figure 24a).

The engraved sherds from bowls and carinated bowls are found throughout the archaeological deposits at the site. These include: sub-mound midden zone in the east Trench ( $\mathrm{n}=5$, see Figure $24 \mathrm{c}-\mathrm{d}, \mathrm{f}, \mathrm{h})$; west Trench, sub-mound midden zone ( $n=3$, see Figure $24 \mathrm{~g}$, j); the west Trench, mixed levels $(n=3)$; submound midden zone in the central Trench section $(n=1)$; upper levels in the mound $(n=2)$; midden east of the mound ( $n=9$, see Figure 24a, i); and the surface ( $n=12$, see Figure $24 b)$. Most are from sub-mound midden zone deposits, in the midden deposits east of the mound, and on the surface.

There are 14 engraved bottle body sherds in the Keith site fine wares, which accounts for 18 percent of the fine wares in the Middle Caddo period ceramic assemblage. Thirteen sherds have curvilinear lines (Figure 25b) and the other has diagonal lines, a hatched triangle element, and a hatched circle element (Figure 25a). This sherd was recovered in the sub-mound midden zone in the west Trench. In the 1934 collection, the other bottle sherds are from the surface $(n=9)$ and mixed levels in the west Trench $(n=2)$. None of the bottle sherds have a clay pigment rubbed in the engraved lines.

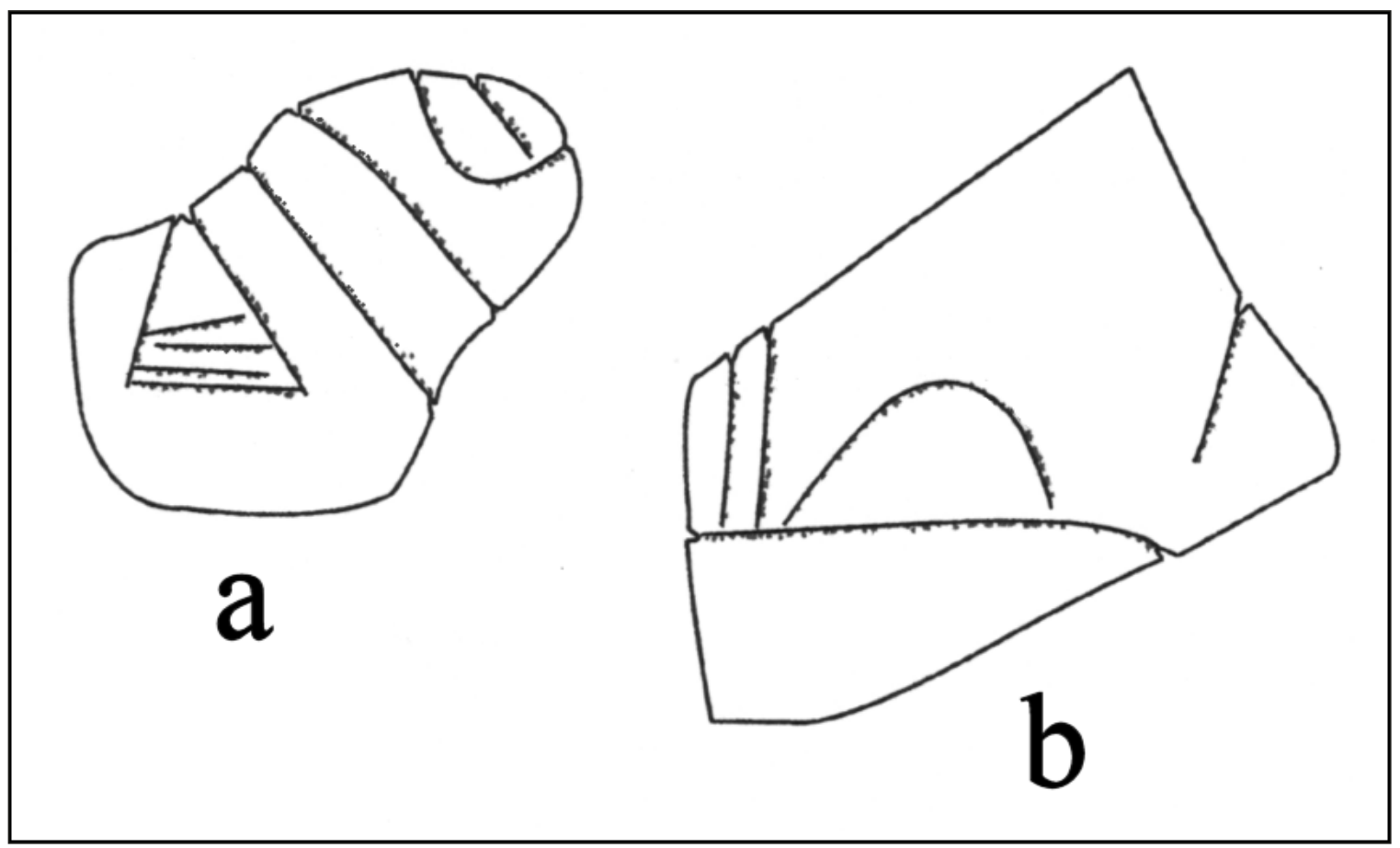

Figure 25. Engraved bottle body sherd decorative elements.

Four engraved rims and four lower rim/body sherds from the Keith site are from Ripley Engraved carinated bowls (Figure 26a-f); the rims have direct profiles and rounded, exterior folded lips. These have horizontal scroll and other scroll elements as well as one lower rim sherd with part of a scroll and circle motif; none have a clay pigment rubbed in the engraved design. These sherds comprise the best 
evidence for a later use of the site after ca. A.D. 1430, during the Late Caddo period Titus phase. The Ripley Engraved fine ware sherds are from surface, west Trench, mixed levels, and the upper levels of the trench through the mound. Their absence from sub-mound midden zones or lower levels in the mound, as well as in the midden east of the mound, would seem to clearly suggest that the mound at the Keith site was not constructed during the Late Caddo period and the midden deposits east of the mound generally accumulated at the same time as the mound did, and it was little used even after ca. A.D. 1430.

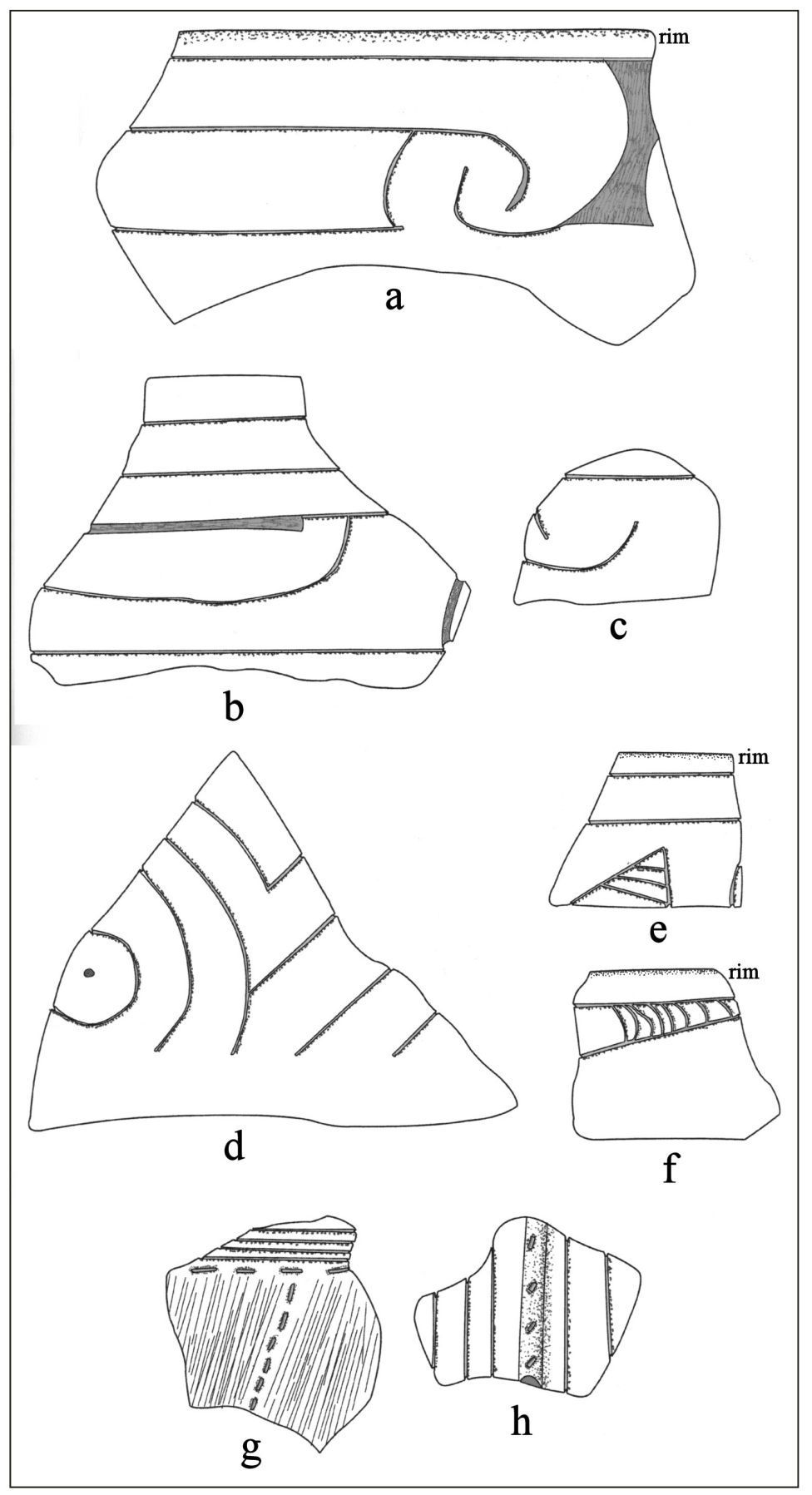

Figure 26. Late Caddo fine ware and utility ware sherd decorative elements: a-f, Ripley Engraved; g, incisedpunctated-brushed; $h$, appliqued-incised. 


\section{Red Slipped}

Red-slipped sherds are quite common in the decorated sherd assemblage, comprising, as previously mentioned, 38 percent of the fine wares (see Table 11). The seven rims are from Sanders Plain bowls or carinated bowls (see Suhm and Jelks 1962:Plate 70), and have direct rims and rounded ( $\mathrm{n}=5$ ) or roundedinterior beveled lips $(n=2)$. The body sherds have exterior slipped only $(n=19)$ or interior/exterior slipped $(n=29)$ decorative elements; none appear to be from bottles. In the 1934 work, these red-slipped sherds were recovered in the sub-mound midden $(n=4)$, in the midden east of the mound $(n=13)$, on the surface $(n=11)$, in the upper levels or strata of the mound $(n=5)$, in the west trench $(n=1)$, in a test trench east of the mound $(n=1)$, and from unknown intra-site proveniences $(n=5)$.

\section{Red Slipped-Punctated}

The two red-slipped sherds may be from an unnamed variety of Maxey Noded Redware vessels as they have rows of small tool punctations as well as red-slipped surfaces (cf. Suhm and Jelks 1962:Plate 51b-d), not appliqued/noded elements. One is a bone-tempered body sherd with an exterior red slip (possibly from a bottle), while the other is a rim (direct rim and a rounded lip) from a bowl with red slipping on both vessel surfaces.

\section{Plain Sherds}

Plain sherds include rims, base sherds, bottle neck sherds, and sherds from a plain grog-tempered carinated bowl (Table 16). There is also a pedestal leg sherd from the midden deposits east of the mound. In general, 19-20 percent of the plain sherds are from bone-tempered vessels.

Table 16. Plain rim, bottle, and base sherds.

\begin{tabular}{lcc}
\hline Sherd Type & Percent Bone-tempered & $\mathrm{N}$ \\
\hline Carinated bowl & - & 68 \\
Base sherds & $*$ & 81 \\
Bottle neck sherds & 20 & 10 \\
Rims & 19 & 32 \\
\hline
\end{tabular}

*not tabulated

\section{Ceramic Spindle Whorl}

Three ceramic spindle whorl sherds are in the assemblage; they are base sherds. Two of the three are from sub-mound midden deposits, and one is from a bone-tempered vessel. The complete spindle whorl has a $13.0 \mathrm{~mm}$ diameter drilled hole near its center.

\section{Ceramic Pipe Sherds}

There is one Red River long-stemmed pipe sherd in the 1934 UT Keith site artifact assemblage. It is a stem sherd from a grog-tempered Red River long-stemmed pipe (see Hoffman 1967). The exterior diameter of the stem sherd is $12.1 \mathrm{~mm}$, and the interior stem hole is $3.9 \mathrm{~mm}$ in diameter. 


\section{Chipped Stone Tools and Cores}

The chipped stone tools from the Keith site collected during the 1934 UT investigations include four biface fragments and preforms (quartzite and petrified wood), two dart points, and one quartzite Catahoula arrow point from an unknown provenience. The dart points include two Woodland period specimens: a Kent point (brownish-red local chert) from an unknown provenience and an Edgewood point (quartzite) from the lower levels of the midden deposit east of the mound.

A large adze or gouge made from a petrified wood slab, with cortical remnants on one surface, is from an unknown provenience at the site. It has a $72.0 \mathrm{~mm}$ long unifacial working edge, and is $142.1 \mathrm{~mm}$ in length, $84.3 \mathrm{~mm}$ in width, and $26.9 \mathrm{~mm}$ in thickness.

\section{Polished Stones}

There are two polished pebbles in the Keith site collection, both from unknown provenience. They range from 35.1-48.6 $\mathrm{mm}$ in length and 26.0-35.2 $\mathrm{mm}$ in width.

\section{Ground Stone Tools}

There are several celts and celt fragments from the Keith site, including two butt end fragments made from Ouachita Mountains tuff or diorite; these are from sub-mound midden deposits. Another small celt (Figure 27b) is made from a Ouachita Mountains greenstone; it has a $29.7 \mathrm{~mm}$ bit width and a bit height of $19.2 \mathrm{~mm}$. A larger siliceous shale celt (from the west trench) has a wider (47.4 mm) and taller (25.2 $\mathrm{mm}$ ) bit (Figure 27a).

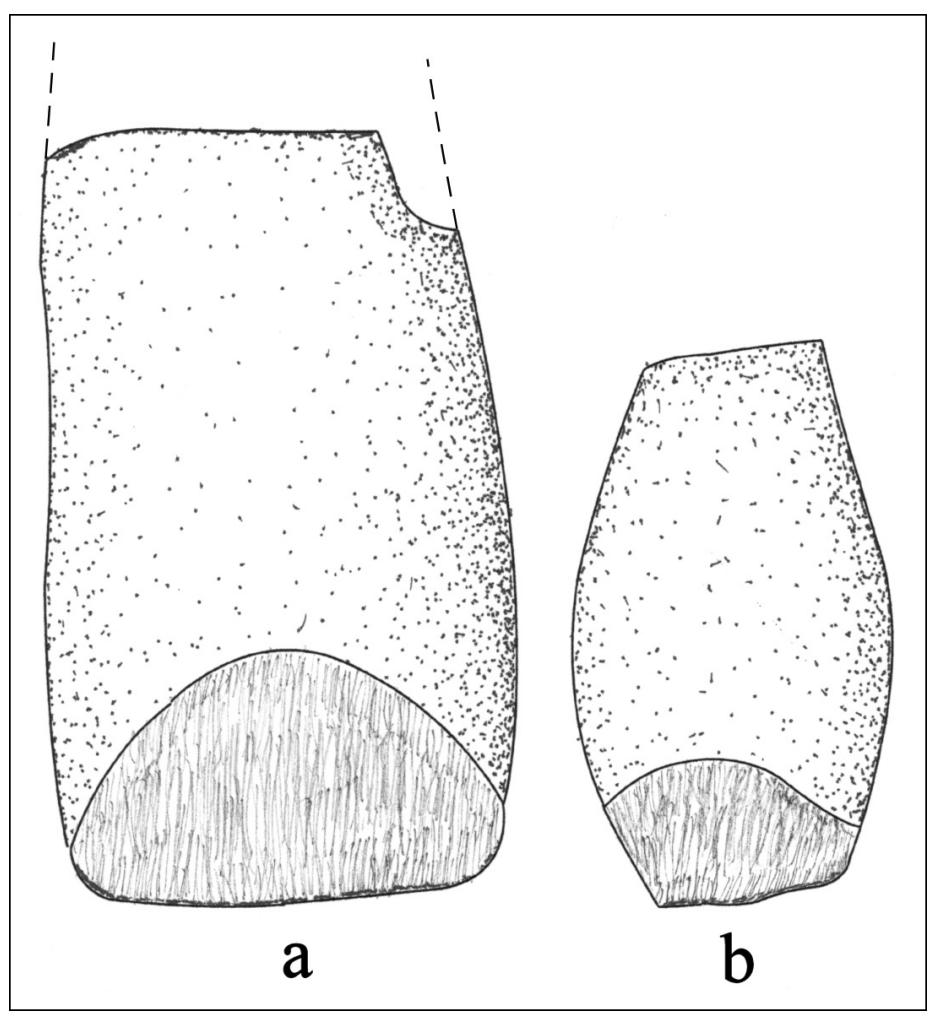

Figure 27. Ground stone celts from the Keith site. 


\section{Bone Tools}

Both bone tools in the Keith site artifact assemblage are made from deer bone fragments recovered in the sub-mound midden deposits. The first is an ulna awl (Figure 28a), 91.1+ $\mathrm{mm}$ in length, and the other is a diaphysis splinter awl or needle with a polished tip (Figure 28b). The fragmentary bone tool is $66.0+$ $\mathrm{mm}$ in length and $10.2 \mathrm{~mm}$ in width.

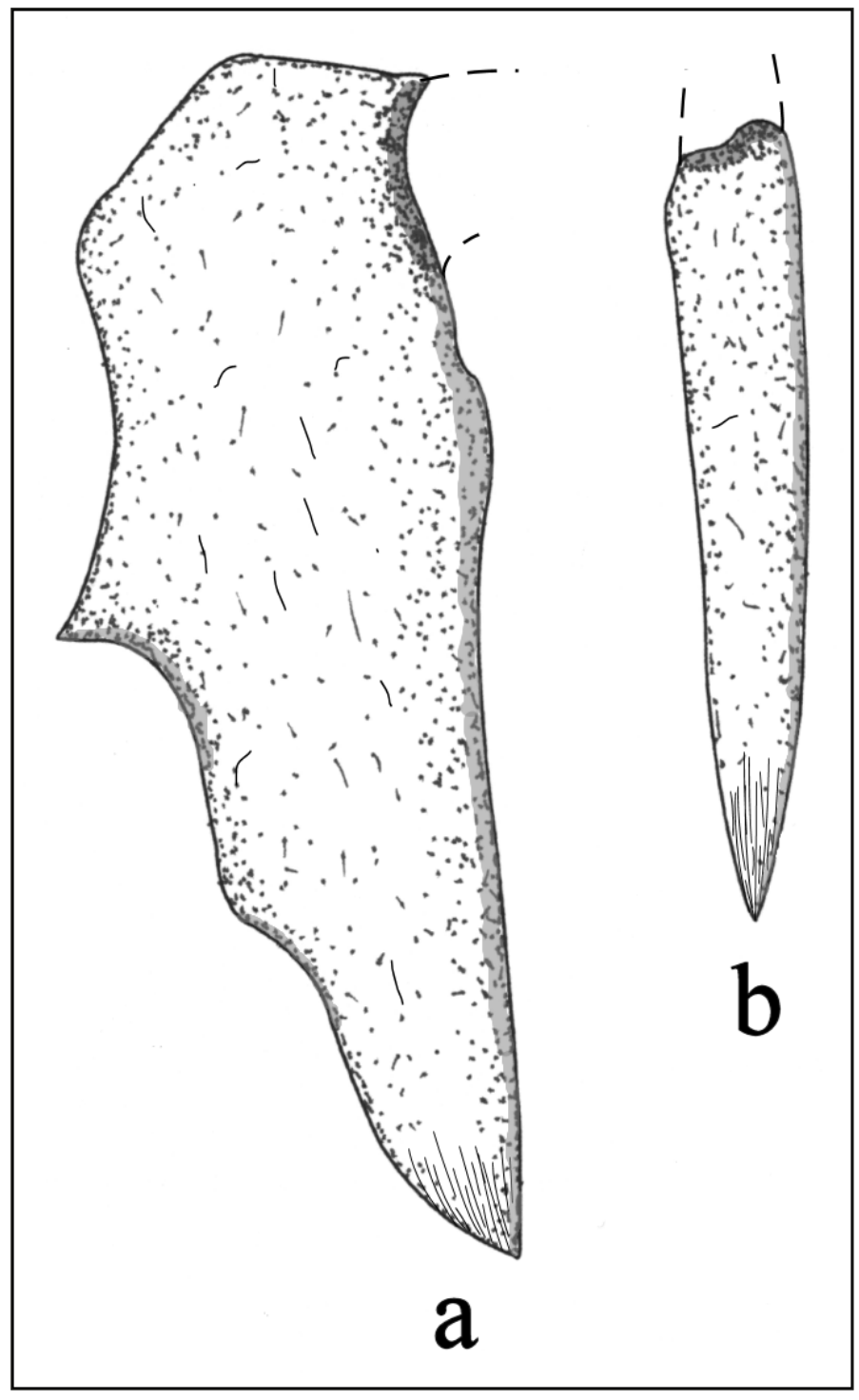

Figure 28. Bone tools from the Keith site.

\section{End Note}

1. Decorated sherds from both the UT and 1971 UT investigations are included in this discussion. 



\section{Chapter 4, Radiocarbon Dates from the Hale and Keith Sites}

Five radiocarbon dates have been recently obtained from the Hale and Keith sites from the collections at the Texas Archeological Research Laboratory at The University of Texas at Austin. All five samples are on unburned deer bones from different proveniences in the mound excavations at the two sites (Table 17). Two other samples of deer long bone fragments from the Keith site (sub-mound zone, midden deposit, lower level, east trench and west trench, top layer, mound fill) contained insufficient collagen to date (Emily Wegeleben, Direct AMS, March 25, 2014 personal communication).

The five dates were calibrated using OxCal v4.2.3 and the IntCal 13 atmospheric curve. The probability densities for the Keith site dates peak from cal. A.D. 1380-1440, with median calibrated ages of A.D. 1404 and A.D. 1420 (see Table 17). Since these dates are from both top layer and sub-mound midden zones in the mound excavations, they imply, if they are accurate, that the mound was built in the very latest years of the Middle Caddo period, and very rapidly (i.e., one generation, ca. 15 years). I have reason to question the two dates because the bones that were submitted for dating were deer bones, a $\mathrm{C} 3$ species, but the delta $13 \mathrm{C}$ values ( -11.7 to $-17.4 \mathrm{o} / \mathrm{oo}$ ) are more consistent with a $\mathrm{C} 4$ species, such as bison (see Wilson 2012:98). This suggests that the delta $13 \mathrm{C}$ values may not be correct, which in turn suggests that the conventional and calibrated ages may be too young, perhaps too young on the order of 100-200 years: that is, ca. A.D. 1280-1340, if the delta 13C values were consistent with a C3 species (i.e., -20 to -21.5\%; see Wilson [2012:98]). Such an adjustment would still suggest that the Keith mound was built during the Middle Caddo period by Caddo peoples, which is corroborated by the ceramic analysis discussed in Chapter 3. The one earlier calibrated radiocarbon date from the site has a 2 sigma age range of A.D. 1276-1495, suggesting major mound construction at the Keith site anytime after A.D. 1276, but more likely instead around A.D. 1383, during the latter part of the Middle Caddo period in East Texas; this is based on the 1 sigma calibrated age range of A.D. 1383-1445 for the composite charcoal sample with the highest probability. Additional radiocarbon dates on plant remains from the Keith site are still urgently needed to confirm the absolute age of the construction and use of the mound there.

All three of the deer bone samples submitted from the Hale site are from deep in the Mound 1 deposits: 7.4-14.0 ft. bs (see Table 17). These dates were expected to fall in the Early Caddo period (ca. A.D. 1000-1200) based on the range of decorated sherds recovered throughout the mound (see Chapter 2, this volume). However, two of the dates from the Hale site have probability densities that have a single peak between cal. A.D. 1260-1290 (8-14 ft. bs), while the third date ( $7.4 \mathrm{ft} . \mathrm{bs})$ has a probability peak between A.D. 1410-1440. At face value, these calibrated dates from the Hale site indicate that Mound 1 was constructed and used in the Middle Caddo period.

Just as dates on deer bone from the Keith site have been questioned, I view the calibrated dates from the Hale site with skepticism. This is because the bones that were submitted for dating were deer bones, a C3 species, but the delta $13 \mathrm{C}$ values (-12.1 to $-16.7 \mathrm{o} / \mathrm{oo})$ are more consistent with a $\mathrm{C} 4$ species, such as bison, or a species that consumed considerable amounts of $\mathrm{C} 4$ grasses. This in turn suggests that the delta $13 \mathrm{C}$ values may not be correct, which would argue that the conventional and calibrated ages may be too young, perhaps on the order of 100-225 years too young if the delta $13 \mathrm{C}$ values were consistent with a C3 species (i.e., -20 to -21.5 o/oo). Such an adjustment would then suggest that the Hale mound was built during the Early to Middle Caddo period by Caddo peoples, perhaps as early as between cal. A.D. 10501170, and as late as cal. A.D. 1200-1300. As with the Keith site, radiocarbon dates on plant remains from the Keith site excavations are still urgently needed to confirm the absolute age of the construction and use of the mound there. 


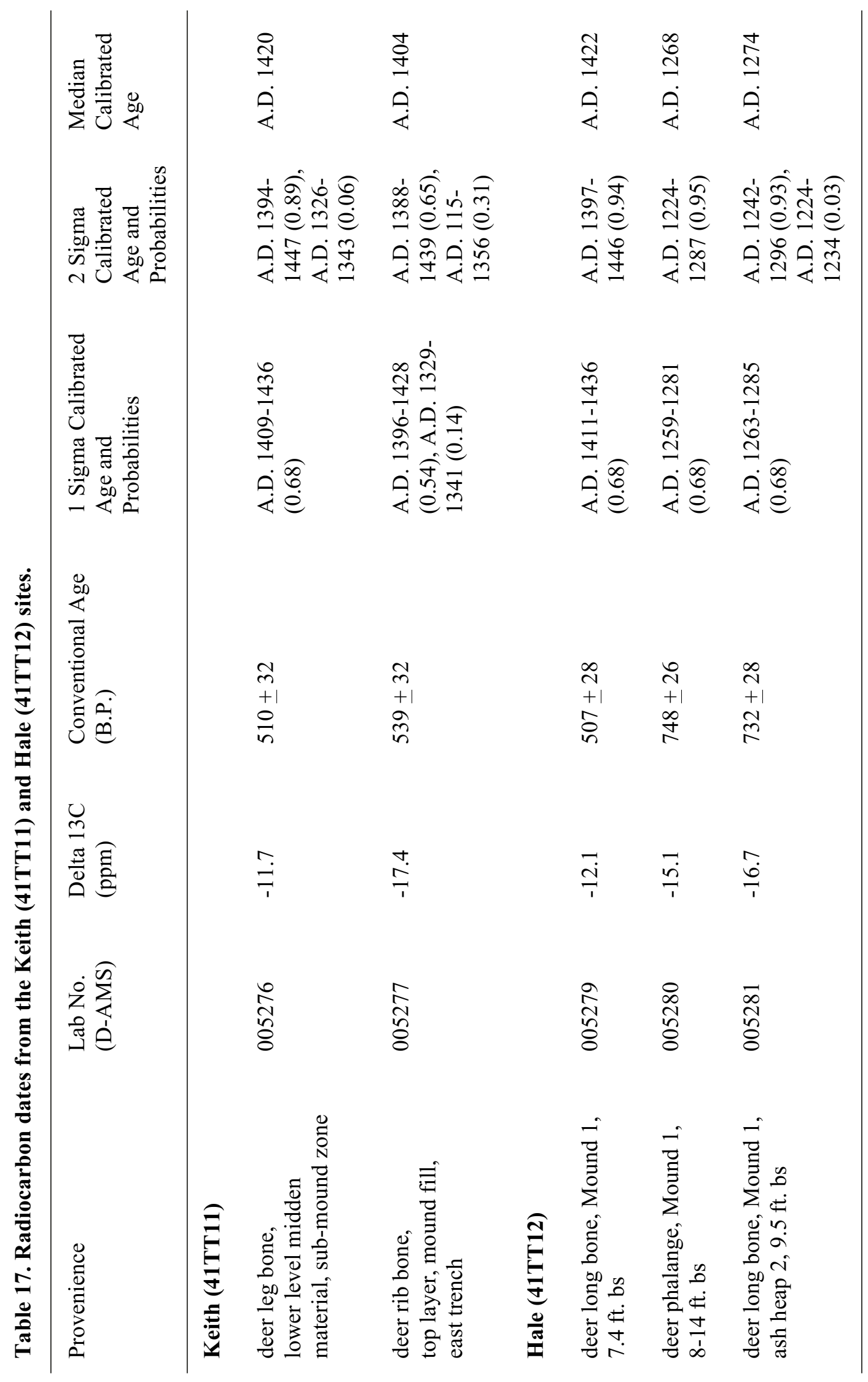




\section{Chapter 5, Summary and Discussion}

This chapter summarizes the archaeological findings from the Hale and Keith sites based on the available archaeological records and artifacts, and also discusses the uses of the sites for mound-related rituals and ceremonies as well as for habitation. The Hale (41TT12) and Keith (41TT11) sites are important ancestral Caddo mound centers in the Big Cypress Creek basin in the Post Oak Savanna of East Texas. Between them, the mounds appear to have been constructed by Caddo peoples between ca. A.D. 1000-1400, although they may not have been used contemporaneously. These mound sites were likely the nexus of different Caddo communities, as they contained evidence of mounds and ritual buildings (on as well as underneath the mounds), as well as inferred religious practices and ceremonies that were conducted at the sites and in the temples and other important buildings on the mounds, that were key to integrating different farmsteads and households in Big Cypress Creek basin communities.

The research conducted on the available records from the 1934 excavations at the two sites and collected archaeological data was done with the goal of ascertaining (1) when were the sites occupied and when were the mounds on them constructed, and (2) what were the mounds and the sites used for? The Keith site has one relatively large mound containing at least $16,450 \mathrm{~m}^{3}$ of earth, while the Hale site has six mounds, extensive habitation debris, and likely at least one or more plaza areas. The two largest mounds at the Hale site, both platform mounds, range from containing at least $4100-5490 \mathrm{~m}^{3}$ of earth; the four smaller mounds at the Hale site each contain only between 112-202 $\mathrm{m}^{3}$ of mound deposits.

The L. A. Hale Mound site (41TT12) is situated on a broad alluvial terrace of Blundell Creek, a southward-flowing tributary to Big Cypress Creek. The excavations at the site by the University of Texas at Austin (UT) under the direction of A. T. Jackson were completed in May 1934. The principal component at the site is apparently an Early Caddo (ca. A.D. 1000-1200) mound center with extensive midden deposits. There are six mounds at the site, two large platform mounds (Mounds 1 and 2) and four low mounds that cover occupational deposits and burned house structures. There are also four large midden areas adjacent to the earthen mounds as well as at least one borrow pit. UT excavations were in the two platform mounds and three of the small mounds (Mounds No. 3-5).

The analysis of recovered ceramics from the Hale site focused on the decorated sherds. Most (76 percent) are from grog-tempered vessels, and approximately 84 percent are from utility wares. Factoring in the plain rims, approximately 43 percent of the rims in the Hale site ceramic assemblage are from plain wares (from carinated bowls, simple bowls, and jars). Utility ware sherds are dominated by sherds from incised $(n=113)$, punctated ( $\mathrm{n}=151$, principally fingernail punctated), and incised-punctated $(\mathrm{n}=15)$ vessels. Utility ware types identified in the assemblage include Coles Creek Incised, var. unspecified, Canton Incised, Crockett Curvilinear Incised, Davis Incised, Dunkin Incised, Kiam Incised, and Weches Fingernail Impressed, var. Weches. There are a few probable post-A.D. 1430 utility wares in the assemblage, including Harleton Appliqued ( $n=3)$, brushed $(n=4)$, brushed-incised $(n=1)$, and La Rue Neck banded $(n=3)$ sherds. The Early Caddo period engraved sherds from the Hale site include sherds from bowls and carinated bowls $(n=32)$ as well as bottles $(n=10)$. The fine ware bowl and carinated bowl sherds, as well as the bottle sherds, in the decorated sherd assemblage are primarily from Holly Fine Engraved and Spiro Engraved vessels with fine line decorative elements. There is a rim from an engraved variety of East Incised, and there are also rims from Hickory Engraved bowls. There are also 11 red slipped sherds in the fine wares from the Hale ceramic sherd assemblage; they are from Mound No. 1 and Mound No. 5 excavations.

Other material culture remains in the excavated assemblage from the Hale site include Red River

long-stemmed pipe sherds, a possible clay figurine fragment, bone tools (from Mounds No. 1 and No. 5), an alligator tooth pendant from Mound No. 1, and a variety of stone tools, a quartz crystal, and pebble 
and cobble-sized pieces of stones or clay used as pigments; the latter are all from Mound No. 1. Among the chipped stone tools are Paleoindian and Middle Archaic-Woodland period dart points, Alba and corner-notched arrow points, and one finished biface. A single ground stone celt was found on the surface of the site.

Three deer bone samples submitted for radiocarbon dating from the Hale site are from deep (7.4$14.0 \mathrm{ft}$. bs) in the Mound 1 deposits. These dates were expected to fall in the Early Caddo period (ca. A.D. 1000-1200) based on the range of decorated sherds recovered throughout the mound, but two of the dates from the Hale site have probability densities that have a single peak between cal. A.D. 12601290 (8-14 ft. bs), while the third date (7.4 ft. bs) has a probability peak between A.D. 1410-1440. These calibrated dates from the Hale site would seem to indicate that Mound 1 was constructed and used in the Middle Caddo period. On archaeological grounds, primarily the decorated ceramics, ceramic pipe sherds, and Alba arrow points, I suggest instead that the Hale mound was built during the Early to Middle Caddo period by Caddo peoples, perhaps as early as between cal. A.D. 1050-1170, and as late as cal. A.D. 1200-1300.

The George L. Keith site (41TT11) is located on a terrace remnant and the floodplain of Hart Creek, a southward-flowing tributary to Big Cypress Creek. The one mound at the site, $4.6 \mathrm{~m}$ in height and 48.7 x $73 \mathrm{~m}$ in width and length, was trenched by UT in 1934, led by archaeologist Walter R. Goldschmidt. That work exposed a series of sub-mound and mound platform structures, several small associated midden deposits, as well as an outdoor activity area marked by post holes, pits, and concentrations of ash and charcoal.

There was a black midden deposit beneath the mound itself, followed by layers of sandy and clayey loam mound fill intermixed with midden debris, perhaps in two or more stages. Excavations into the submound midden deposit identified post holes and other features at ca. $3.6 \mathrm{~m}$ below the surface. They were exposed underneath thin layers of black carbonaceous material (1-5 mm thick), ash, yellow clay (5 cm thick), and sand (6.3-9 cm thick), with the top of the post holes in a second underlying black layer. These deposits indicate that the Caddo structure that was built in the midden deposits was burned down, probably deliberately, before it was capped with clay, structural debris, and the beginning mound fill zones. These features include several sets of post holes, including portions of a circular structure post hole pattern (Feature 1) as well as associated internal posts and small midden areas, two north-south rows of posts a few meters east and west of Feature 1, that are between 2.5-6.7 m long, that may mark a wooden post enclosure around the structure, midden deposits (Features 3 and 6), and several $0.6 \mathrm{~m}$ diameter pit features (Features 4 and 5) that originated in sub-mound contexts in the western portion of the trench. The circular structure is estimated to be approximately $9 \mathrm{~m}$ in diameter. There was also a concentration of daub about $0.9 \mathrm{~m}$ bs in the central portion of the mound which indicates that a structure stood on the mound platform, and then was burned and capped with additional mound fill sediments.

A small midden deposit was present ca. $275 \mathrm{~m}$ southwest of the mound, and trenching in a terrace remnant east of the mound recovered a limited number of pottery sherds that are primarily stylistically similar to those sherds found in the midden under the mound and in the mound fill. In the 1950s, a Late Caddo Titus phase cemetery dating to after ca. A.D. 1550 was excavated about $100 \mathrm{~m}$ east-southeast of the earthen platform mound at the site.

The ceramic sherds from the Keith site are primarily from grog-tempered vessels (73 percent), and 71.5 percent are from utility wares $(n=364)$. The remainder are from fine ware (i.e., engraved, redslipped, and red-slipped-punctated, $n=145$ ) vessels. Among the utility ware sherds, the most common decorative methods on the sherds include incised $(n=155)$, punctated $(n=87$, fingernail and tool punctated 
jar rims), brushed $(n=55)$, and incised-punctated $(n=44)$. Identified types that are associated with the principal Caddo occupation are Canton Incised, Crockett Curvilinear Incised, Davis Incised, Dunkin Incised, East Incised, Pease Brushed-Incised, and Weches Fingernail Impressed, var. Alto. The engraved sherds in the primary Middle Caddo component are from carinated bowls, compound bowls, and bowls, as well as a few bottle sherds with curvilinear lines, diagonal lines, hatched triangle elements, and a hatched circle element. Many are from either Sanders Engraved or Hickory Engraved vessels, and there are also a number of sherds $(\mathrm{n}=16)$ with hatched or cross-hatched zones, including curvilinear, triangular, and diagonal or ladder-shaped zones. The use of hatched or cross-hatched engraved lines to fill zones is a common characteristic of East Texas ceramic assemblages beginning in Middle Caddo period times. The common red-slipped sherds are from Sanders Plain bowls or carinated bowls, and there are two possible Maxey Noded Redware rim and body sherds.

There are also a number of sherds from a post-A.D. 1430 Titus phase occupation of the site. These come primarily from UT surface collections or in excavations in habitation deposits on the terrace remnant east of the platform mound, and include most of the brushed sherds, brushed-punctated rim sherds, one La Rue Neck Banded rim, and four Ripley Engraved carinated bowl sherds. These sherds are absent from sub-mound midden zones or lower levels in the mound, clearly suggesting that the mound at the Keith site was not constructed during the Late Caddo period. The midden deposits east of the mound generally accumulated at the same time as the mound did, but this area was used after ca.A.D. 1430 for habitation as well as for a Titus phase cemetery.

Other material culture remains in the assemblage from the Keith site include ceramic spindle whorls, a long-stemmed Red River pipe sherd, bone tools from the sub-mound midden deposits, and polished pebbles. The chipped stone tools include a few biface fragments and preforms, two Woodland period dart points, a Catahoula arrow point, and a petrified wood adze or gouge. Also recovered in the sub-mound midden deposits are four celts or celt fragments.

The probability densities for the two new radiocarbon dates from the Keith site peak from cal. A.D. 1380-1440, with median calibrated ages of A.D. 1404 and A.D. 1420. Since these dates are from both top layer and sub-mound midden zones in the mound excavations, they imply that the mound was built in the very latest years of the Middle Caddo period, and very rapidly indeed. There is one earlier calibrated radiocarbon date from the site obtained by Kenneth M. Brown from charcoal in the mound fill that has a 2 sigma age range of A.D. 1276-1495, suggesting major mound construction at the Keith site anytime after A.D. 1276, but more likely instead after ca. A.D. 1383, during the latter part of the Middle Caddo period in East Texas, based on the calibrated age range (at 1 sigma) with the highest probability.

In summary, the mounds at both the Hale and Keith sites likely were built at different times to elevate and/or cap important structures that were used for religious and political rituals and ceremonies conducted by religious and political leaders in different Big Cypress Creek basin Caddo communities, and the actual construction of the mounds (using different colored and textured fills) had important ritual and symbolic meanings. The volumes of the mounds likely indicate that their construction between the 11th and 15th centuries required the cooperation of large numbers of people and likely multiple social groups. At the Hale site, Mound No. 1 had structural deposits in several zones, marked by concentrated ash zones, a large pit or hearth in association with a thick brick-hard burned soil, and a burned structural zone likely atop the original ground surface; there was also one human cremation in the lower depths of the mound deposits. Mound No. 2 was built over a burned house or temple floor marked by a ca. $20 \mathrm{~cm}$ thick zone of hard-packed ash. Very little evidence of occupational debris was encountered in any of the Mound No. 2 zones. Mound No. 3 was built over an important burned Caddo structure. The large platform mound at the Keith site was built over a $9 \mathrm{~m}$ diameter burned circular structure that had been built 
on the ground surface at that time, and there was a second burned structure higher up in the mound. The large burned structure appears to have been enclosed by two lines of post holes, suggesting access to this important structure was limited. Finally, 1971 work by Kenneth M. Brown, including hand excavated units and auger tests, at the Keith site clearly indicate that the Keith mound was not constructed amidst other associated habitation areas, except for the one area of concentrated midden deposits and structures that were eventually covered up by the mound itself. 


\section{References Cited}

Anderson, D. G.

2012 Monumentality in Eastern North America during the Mississippian Period. In Early New World Monumentality, edited by R. L. Burger and R. M. Rosenwig, pp. 78-108. University Press of Florida, Gainesville.

Anderson, D. G. and K. E. Sassaman

2012 Recent Developments in Southeastern Archaeology: From Colonization to Complexity. The SAA Press, Washington, D.C.

Brown, K. M.

1971a A Preliminary Report on Fieldwork at the G. L. Keith Site: 1934 and 1971. MS on file, TARL.

1971b Fieldwork at the G. L. Keith Site: 1934 and 1971. MS on file, TARL.

n.d. Notes on file, TARL.

Fields, R. C.

2014 The Titus Phase from the Top and Bottom: Looking at Sociopolitical Organization through the Pine Tree Mound and U.S. Highway 271 Mount Pleasant Relief Route Projects. Bulletin of the Texas Archeological Society 85:111-146.

Goldschmidt, W. R.

1934 Field Report of an Excavation Through the George L. Keith Mound, Titus County, Texas; and Test Trenching on the C. T. Coley Farm, Titus County, Texas. MS on file, TARL.

1935 A Report on the Archeology of Titus County in East Texas. Bulletin of the Texas Archeological and Paleontological Society 7:89-99.

Hoffman, M. E.

1967 Ceramic Pipe Style Chronology Along the Red River Drainage in Southwestern Arkansas. The Arkansas Archeologist 8(1):4-14.

Jackson, A. T.

n.d. Agreement for Securing and Preserving Indian Relics from the L. A. Hale Farm. Form on file, TARL.

1934 Trenching of an Earth Mound, L. A. Hale Farm, 2 1 1/2 Miles South of Winfield, Titus County, Texas (Near Edge of Franklin County), Trenched May 11, 1934, to May 28, 1934. MS on file, TARL.

Pauketat, T. R.

2013 An Archaeology of the Cosmos: Rethinking Agency and Religion in Ancient America. Routledge, London and New York.

Perttula, T. K.

2013 Analysis of a Surface Collection from the L. A. Hale (41TT12) Mound Site, Titus County, Texas. Journal of Northeast Texas Archaeology 40:27-30. 
Perttula, T. K., M. Walters, and B. Nelson

2010 Caddo Pottery Vessels and Pipes from Sites in the Big Cypress, Sulphur, Neches-Angelina, and Middle Sabine River Basins in the Turner and Johns Collections, Camp, Cass, Cherokee, Harrison, Morris, Titus, and Upshur Counties, Texas and Sabine Parish, Louisiana. Special Publication No. 10. Friends of Northeast Texas Archaeology, Austin and Pittsburg.

Spielmann, K. A.

2009 Ohio Hopewell Ritual Craft Production. In Footprints: In the Footprints of Squier and Davis: Archeological Fieldwork in Ross County, Ohio, edited by M. J. Lynott, pp. 179-188. Special Report No. 5. National Park Service, Midwest Archeological Center, Lincoln, Nebraska.

Stokes, J. and J. Woodring

1981 Native-Made Artifacts of Clay. In Archeological Investigations at the George C. Davis Site, Cherokee County, Texas: Summers of 1979 and 1980, edited by D. A. Story, pp. 135-238. Occasional Paper No. 1. Texas Archeological Research Laboratory, The University of Texas at Austin.

Suhm, D. A. and E. B. Jelks (editors)

1962 Handbook of Texas Archeology: Type Descriptions. Special Publication No. 1, Texas Archeological Society, and Bulletin No. 4, Texas Memorial Museum, Austin. Reprinted in 2009, Gustav's Library, Davenport, Iowa.

Thurmond, J. P.

1990 Archeology of the Cypress Creek Drainage Basin, Northeastern Texas and Northwestern Louisiana. Studies in Archeology 5. Texas Archeological Research Laboratory, The University of Texas at Austin.

Wilson, D.

2012 Bioarchaeological Evidence of Subsistence Strategies among the East Texas Caddo. In The Archaeology of the Caddo, edited by T. K. Perttula and C. P. Walker, pp. 86-116. University of Nebraska Press, Lincoln. 